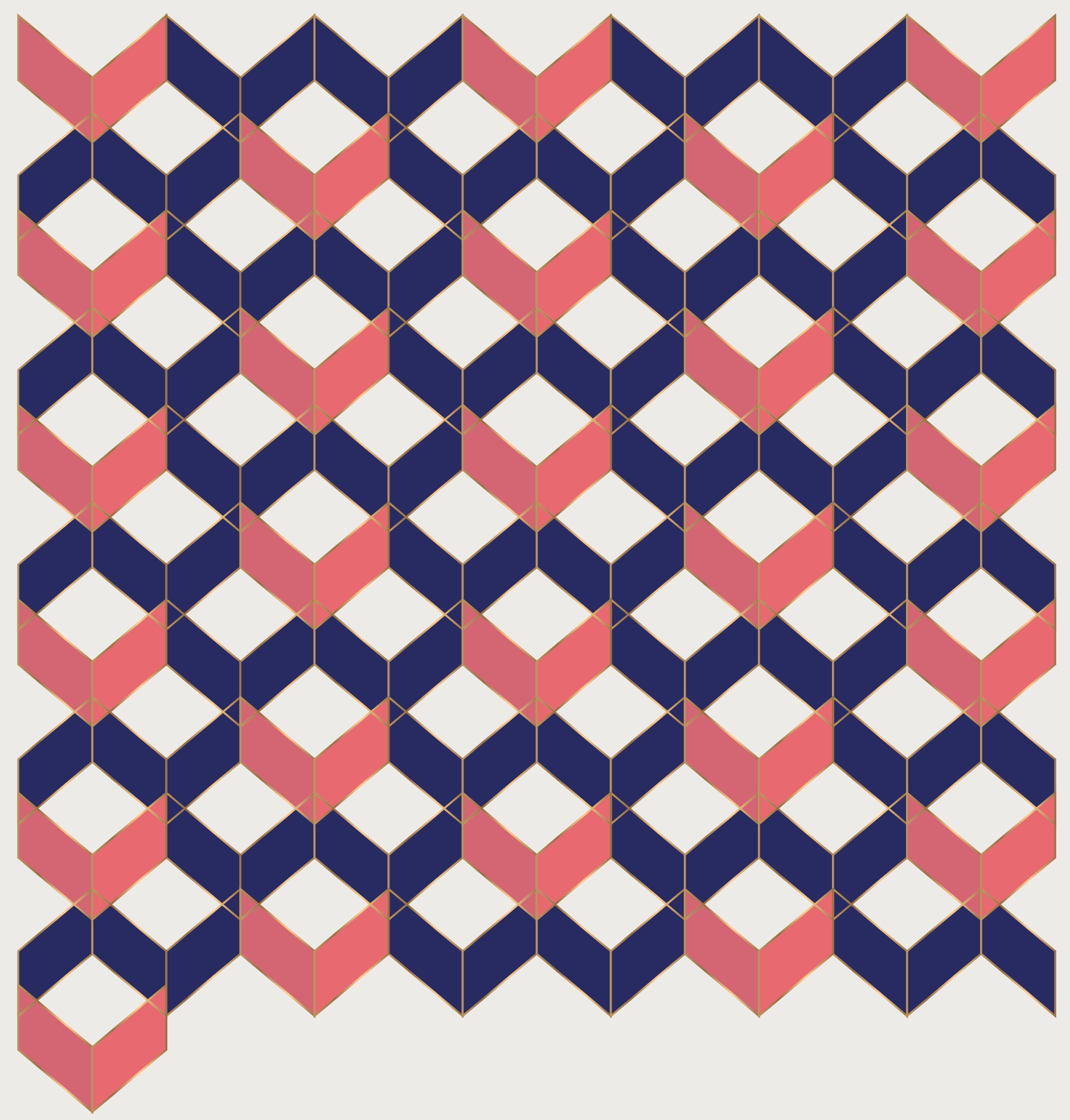

HERANÇA

REVISTA DE HISTÓRIA,

\section{PATRIMÓNIO E}

\section{CULTURA}

2019

VOLUME $\mathbf{2}$ | NÚMERO $\mathbf{2}$

SEMESTRAL (JANEIRO, JULHO)

ISSN (ONLINE): 2184 - 3090 


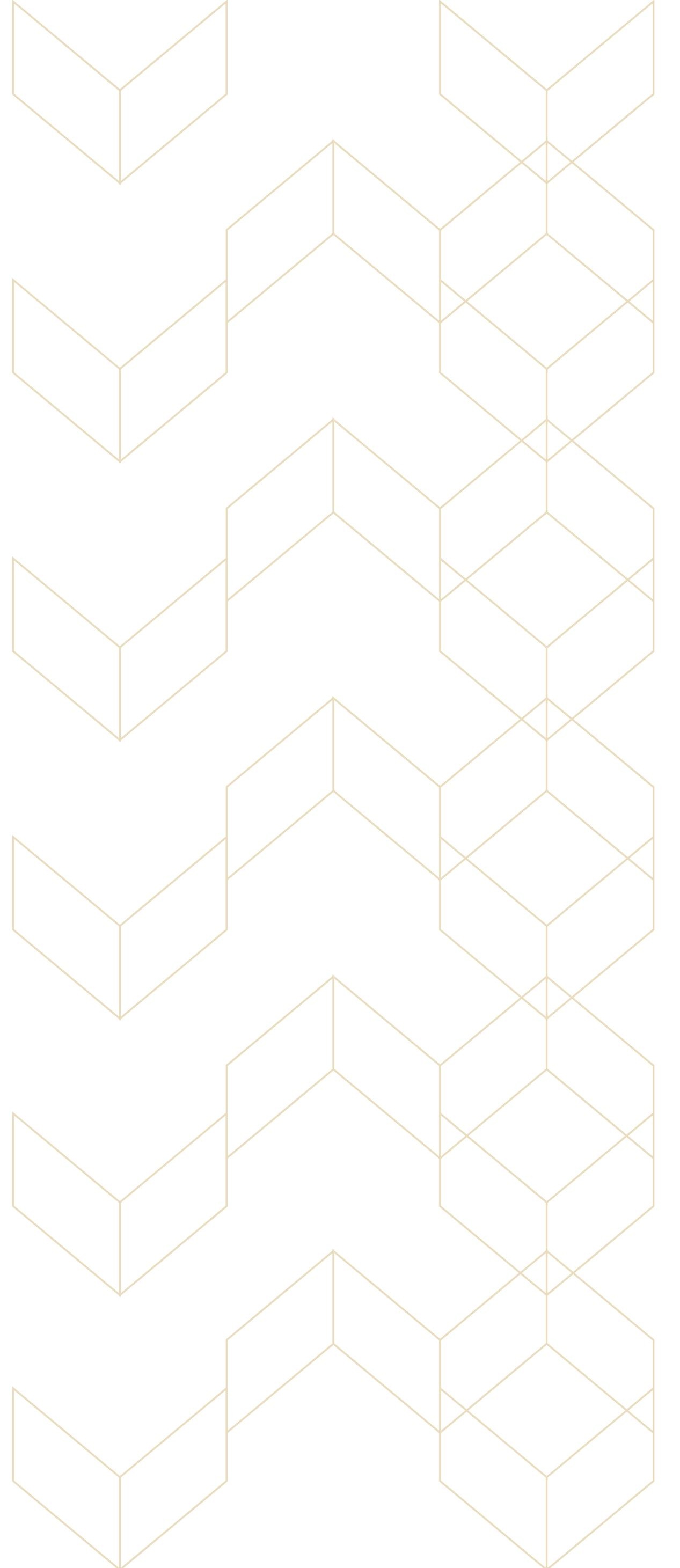




\section{(...) Não abdico da}

matriz cultural de todo a ato político ainda que o seu não entendimento aparcca a alguns como expressão de utopia...

Maria de Lurdes Pintasilgo 


\section{IIERANCA - REVISTA DE IISTÓRIA. \\ PATRIYÓNIO E CULTURA}

\section{pontěditora}

Herança - Revista de História, Património e Cultura

Ponteditora, Sociedade Unipessoal, Lda

Startup Madeira - Campus da Penteada

9020 - 105 Funchal, Madeira

E-mail: geral@ponteditora.org

Telefone: 291723010

URL: ponteditora.org

URL (revista): revistas.ponteditora.org/index.php/heranca

$\boldsymbol{A}$ facebook.com/ponteditora

in linkedin.com/in/ponteditora

twitter.com/ponteditora

@ instagram.com/ponteditora

Editora - Chefe: Investigadora Doutora Isabel Lousada

Periodicidade: Semestral (janeiro, julho)

Propriedade/Editora: Ponte Editora,

Sociedade Unipessoal, Lda.

\section{Composição do Capital da Entidade Proprietária:}

10.000 euros, $100 \%$ propriedade

Ana Leite, M.Sc.

ISSN (online): 2184-3090

ERC: 127195 


\section{EQUIPA EDITORIAL}

\section{EDITORA - CHEFE}

Isabel Lousada - Isabel Lousada, Investigadora Auxiliar de nomeação definitiva da NOVA FCSH. Licenciada, Mestre e Doutora pela Universidade Nova de Lisboa tem feito o seu percurso académico na interseção das áreas científicas nas quais se inscrevem os Estudos sobre as Mulheres. Atualmente integrada no CICS.NOVA é também investigadora colaboradora do CLEPUL - Grupo de Investigação 6 - Brasil-Portugal: Cultura, Literatura e Memória, no qual co-coordena o projeto "Senhoras do Almanaque", com Vania Pinheiro Chaves. Na CIDH - Cátedra Infante D. Henrique coordena com Isabel Baltazar o grupo de investigação MCCLA - Mulheres, Cultura, Ciências, Letras e Artes. Sócia fundadora do MIMA - Museu Internacional das Mulheres - Associação; Conselheira da CIG - Comissão para a Cidadania e Igualdade de Género. Membro da Direção do Sub-grupo WWIH - Women Writers in History da rede DARIAH; Vice-Presidente da AMONET Associação Portuguesa de Mulheres Cientistas; Vogal da Secção de História da Medicina da SGL Sociedade de Geografia de Lisboa). Membro da SPESXVIII - Sociedade Portuguesa de Estudos do Século XVIII, atualmente na Presidência. Sócia da APE - Associação Portuguesa de Escritores e do P.E.N. Clube Português.

\section{EDITORA ADJUNTA}

Ana Raquel Machado - Mestre em Arte, Património e Teoria do Restauro pela Faculdade de Letras da Universidade de Lisboa | Pós-graduada em Gestão Cultural pelo ISCTE Instituto Universitário de Lisboa. 


\section{CONSELIIO CIENTÍFICO}

Ana Maria Pires da Silva - Doutorada em Antropologia, na especialidade de Antropologia das Sociedades Complexas; Foi Quadro Superior no Ministério da Educação; Lecionou a cadeira de Introdução ao Pensamento Contemporâneo na Universidade Lusófona; É vice-presidente da Secção de História da Medicina da Sociedade de Geografia de Lisboa; Fundadora e Presidente do Conselho Fiscal da AC RIM Associação de Cancro do Rim Portugal. Voluntária no Arquivo Histórico do Patriarcado de Lisboa. Ana Soares Pacheco - PhD em Museologia, Universidade Lusófona; Mestre em Ciência da Arte, Universidade Federal Fluminense; Docente, Universidade Federal de Minas Gerais.

António José de Oliveira - PhD em História da Arte Portuguesa, Faculdade de Letras da Universidade do Porto.

Bruno Miranda Braga - Docente e Mestre em História Social, Universidade Federal do Amazonas; Pós-Graduação em Gestão e Produção Cultural, Universidade do Estado do Amazonas.

Diana Alexandra Simões Carvalho - Mestre em História e Património, Faculdade de Letras da Universidade do Porto; Investigadora e Assistente Cultural.

Daniela Melo - PhD em Political Science and Government, University of Connecticut; Docente de Government \& International Relations, Connecticut College [https://www.conncoll.edu/directories/ faculty-profiles/daniela-melo/].

Evelyne Phibel - Mestre em História da Arte Portuguesa, Faculdade de Letras da Universidade do Porto. Isabel Baltazar - PhD em História e Teoria das Ideias, Universidade Nova de Lisboa; Investigadora, FCSH/UNL e CEIS 20 da Universidade de Coimbra.

Joana Balsa de Pinho - Doutora em História da Arte, Faculdade de Letras da Universidade de Lisboa; Investigadora Integrada do CLEPUL - Centro de Literaturas e Culturas Lusófonas e Europeias, Universidade de Lisboa.

Maria da Conceição Castel-Branco - Professora Auxiliar de nomeação definitiva do Departamento de Línguas, Culturas e Literaturas Modernas, da Faculdade de Ciências Sociais e Humanas, Universidade Nova de Lisboa. Membro e investigadora do CETAPS - Centre for English, Translation and AngloPortuguese Studies.

Pedro Urbano - PhD em História, Faculdade de Ciências Sociais e Humanas da Universidade Nova de Lisboa; Professor de História de Portugal, Escola Superior de Educadores de Infância Maria Ulrich (ESEIMU); Investigador e membro das Redes Culturais Femininas entre Portugal e Alemanha - Fundação para a Ciência e Tecnologia; Investigador do Centro de Estudos Clássicos - FLUL e do Instituto de História Contemporânea - UNL.

Roseline Oliveira - PhD, Universidade Federal de Alagoas, Brasil; Professora de Arquitetura e Urbanismo.

Tiago Rodrigues - Investigador do ARTIS-IHA e do CH-UL| Mestre em Arte, Património e Teoria do Restauro pela Faculdade de Letras da Universidade de Lisboa.

Vanda de Sousa - Licenciada em Filosofia (1986) pela Universidade Nova de Lisboa - Faculdade de Ciências Sociais e Humanas, pós-graduada em Ciências da Informação (1993) pela Universidade Católica Portuguesa, Mestre em Indústrias Culturais (2003) pela Universidade Católica Portuguesa e Doutorada em Estudos de Cultura (2011) pela Universidade Católica Portuguesa. Professora Adjunta Convidada da ESCS - IPL, na área de Audiovisual e Multimédia, faz parte do conselho científico da licenciatura, vicecoordenadora da mesma licenciatura e pertence ao conselho científico da Pós-Graduação em Storytelling, na mesma instituição, onde também é docente. 


\section{ESTATUTO EDITORIAL}

I - A Herança - Revista de História, Património e Cultura, conhecida também pelas formas abreviadas de Herança ou Revista Herança, é uma publicação periódica. Propriedade da Editora: Ponteditora.

III - A Herança dedica-se à pluralidade de temas que envolvem a História, o Património, material e imaterial, e a Cultura.

III - A linha editorial da Herança explora temas como a Arqueologia, Arquitetura, História da Arte, Conservação e Restauro, Gestão e Estudos da Cultura, entre outras.

IV - A Herança tem por missão fomentar a ciência de forma a estimular a investigação e a elaboração de estudos e ensaios nos países da CPLP e da Diáspora de língua portuguesa.

V - A Herança é editada semestralmente, em papel, em Portugal

e, quando se justificar, na CPLP, sendo disseminada no resto do mundo através da Internet.

VI - A Herança terá, aproximadamente, 80 a 100 páginas de formato A4 e uma tiragem em papel inferior a 1000 exemplares.

VIII - A revista Herança destina-se a professores, investigadores e académicos, nacionais ou estrangeiros.

VIIII - A Herança apresenta um corpo editorial técnico e

científico, aberto a académicos, investigadores e profissionais oriundos de diversas organizações e empresas relacionadas com a investigação cultural e histórica.

IX - A revista Herança publica artigos académicos e científicos, originais e de revisão.

X - A Herança publica em português, podendo excecionalmente apresentar artigos noutra língua, desde que se trate de uma língua reconhecida internacionalmente no meio académico e profissional, como por exemplo em inglês.

XI - A revista Herança pretende promover o intercâmbio de ideias, experiências e projetos entre os autores e editores, contribuindo para a reflexão histórica, cultural e patrimonial, e para a sua ligação com a sociedade.

XII - A Herança assume o compromisso de assegurar o respeito pelos princípios deontológicos e pela ética profissional dos jornalistas, assim como pela boa-fé dos leitores, nos termos $n^{\circ} 1$ do artigo $17^{\circ}$ da Lei de Imprensa. 


$$
\text { VOL. } 2 \mid \mathbf{N}^{\circ} 2
$$



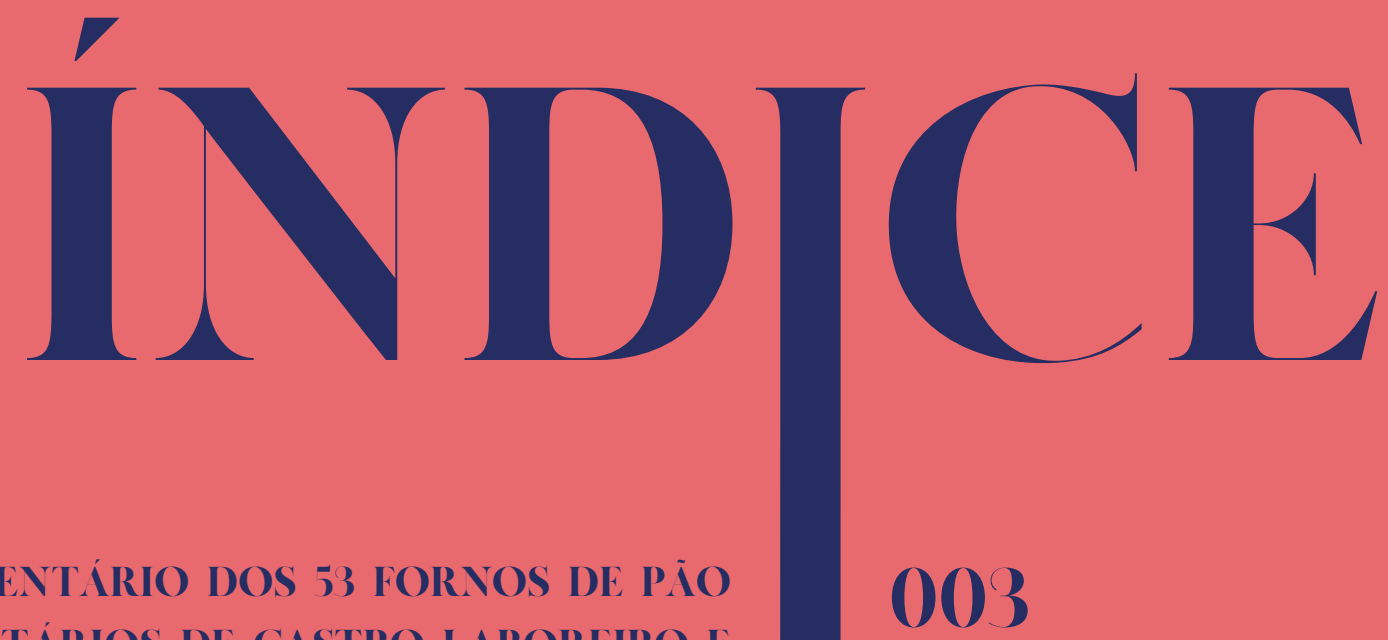

COMIUNITÁRIOS DE CASTRO LABOREIRO E LAMAS DE MOURO (2011-2017). OS FORNOS DAS "INVERNEIRAS" - PARTE 2

Inventory of the 53 bread ovens of Castro Laboreiro and Lamas de Mouro (2014-2017). The bread ovens at the "inverneiras" - part 2

PATRIMÓNIO MISICAL DE ÉVORA NO INÍCIO DE OITOCENTOS: UN MISERERE DE 019 FR INCISCO IGNÁCIO MOREIRA E POSSÍVEIS CONTEXTOS INTERPRETATIVOS

Musical heritage of Évora at the beginning of the 19th century: a Miserere by Francisco Ignacio Moreira and possible interpretative contexts

PATRIMÓNIO MLSICAL NA CATEDRAL DE ANGRI NO SÉCULO XVII: TRESS LIVROS DE

\section{9} POLIFONIA VOCAL SACRA E O SEU POSSÍVEL CONTEXTO

Musical heritage in Angra Cathedral in the seventeenth century: three books of sacred vocal polyphony and their possible context

A INOVACIOO ARQUITETÓNICA NOS ATELIERS

DE LISBOA E OEIR AS. ENTRE $1867 \wedge 1912$ 


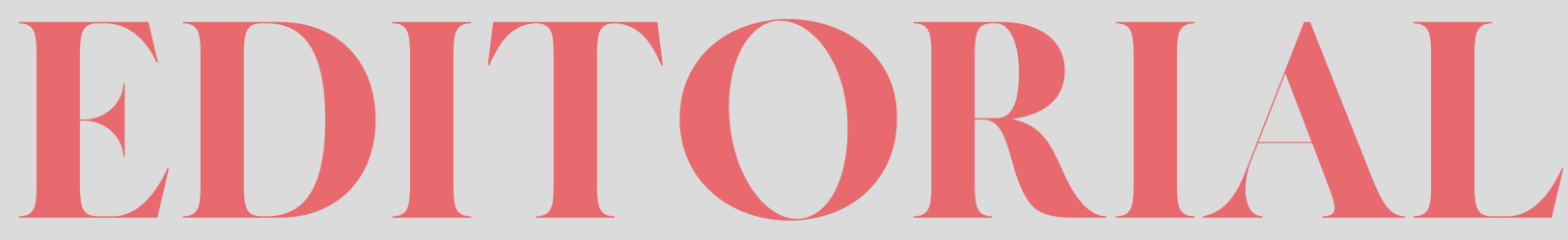

Editora - chefe Investigadora Doutora Isabel Lousada

Email: iclousada@gmail.com

Eles não sabem que o sonho

É uma constante da vida

Tão concreta e definida

Como outra coisa qualquer [...]

Que é retorta de alquimista,

Mapa do mundo distante,

Rosa-dos-ventos, Infante

Caravela quinhentista

Que é Cabo da Boa Esperança,

Ouro, canela, marfim...

$[\ldots]$

António Gedeão, Pedra Filosofal

O ano estás prestes a terminar e ainda é ao cair da folha que trazemos à luz o segundo volume da Revista Herança. É este um tempo de contradições, entre os auspícios de um tempo de celebração natalícia e um ano por começar que permite sonhos ainda não realizados. Mas é simultaneamente um tempo de balanço e, por isso mesmo, a dualidade se faz presente entre um passado, já memória, e um futuro que se torna mais presente.

2019 foi um ano de muitas perdas, assinaladas pelo desaparecimento de grandes nomes da cultura portuguesa, das letras às artes, lembramos Agustina Bessa-Luís, Diogo Freitas do Amaral, Luís Barros, António Tavares Teles ou José Mário Branco. Mas, por outro lado, Portugal conquistou lugares cimeiros: Elisa Ferreira eleita comissária da comissão e reformas da UE, também pela primeira vez dirigida por uma mulher, Ursula von der Leyen. 
Se, por um lado, estão lançadas as sementes para uma mudança na representação de Género, por outro lado, essa mudança repercute-se nas prioridades na defesa do ambiente, do planeta e da própria humanidade. Inalcançadas as metas do acordo de Paris, estamos cientes de que cabe aos jovens, como Greta Thunberg, o despertar para uma consciência ecológica que se faz urgente e deverá ser de todos como simbolicamente é representada em duas de capas de revistas icónicas: a da Times (Junho, 2019) sob o título O nosso Planeta está a afundar-se e a da National Geographic (Novembro, 2019) sob o título Mulheres Um Século de Mudanças.

Sem esse despertar, as memórias de 2019 talvez não possam chegar a ser Herança e a cumprir os sonhos que o futuro de 2020 nos alimentam, no caminho de uma maior equidade de género nas instituições, nos salários, no reconhecimento do mérito da mulher, na partilha de causas que só serão viáveis se partilhadas por homens e mulheres. O dia 25 de novembro, dia internacional para a eliminação da violência contra as mulheres, ganhou foros nacionais e internacionais substantivos cientes de que a erradicação da violência, como a da pobreza, são um imperativo categórico. Sendo causa social e cultural, não deixa ainda de ser uma causa servida pela ciência que comemoramos a 24 de novembro, dia nacional da cultura científica, associado ao nome de Rómulo de Carvalho (assinalando a data do seu nascimento), cientista português que se fez também poeta sob o nome de António Gedeão para quem O Sonho comanda a vida... 
INVENTÁRIO DOS

53 FORNOS DE PĨO

CONIUNITÁRIOS DE

CASTRO LABOREIRO E

LANAS DE NOURO (2011

2017). OS FORNOS DAS

"INVERNEIRAS" - PARTE 2

Inventory of the 53 bread ovens of Castro Laboreiro and Lamas de Mouro (2014-2017). The bread ovens at the "inverneiras" - part 2

Diana Alexandra Simões Carvalho

E-mail: dianacarvalho.pt@gmail.com

Faculdade de Letras da Universidade do Porto

O mérito e importância deste trabalho foram oficialmente

reconhecidos pela Câmara Municipal de Melgaço e pela

Associação para o Desenvolvimento das Regiões do

Parque Nacional da Peneda-Gerês.

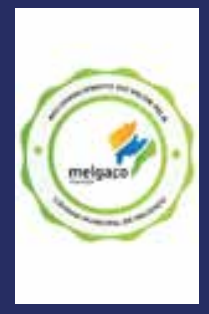

"Selo de qualidade" do Município de Melgaço.

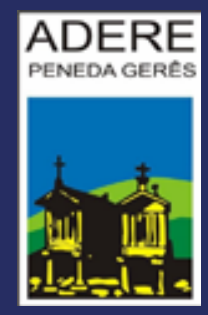

"Trabalho de mérito

reconhecido pela ADERE PENEDAGERÊS". 


\title{
Resumo
}

Este segmento do inventário dos 53 fornos de pão comunitários de Castro Laboreiro e Lamas de Mouro é dedicado aos 21 fornos de pão situados nas "inverneiras" (700-1000mts) de Castro Laboreiro. A contagem inclui os dois fornos demolidos durante o século XX, e também um forno arruinado, dos quais ainda existem memórias coletivas e ou referências documentais.

Palavras-chave: Inventário; Fornos de Pão; Castro Laboreiro; Lamas de Mouro; Melgaço; Parque Nacional da Peneda-Gerês.

\begin{abstract}
The present segment of the inventory of the 53 communal bread ovens of Castro Laboreiro and Lamas de Mouro is dedicated to the 21 bread ovens located at the "inverneiras"(700-1000mts) at Castro Laboreiro. The inventory also includes the two bread ovens that were demolished during the twentieth century, and also a ruined oven, of which there are still collective memories and documental references.
\end{abstract}

Keywords: Inventory; Bread Ovens; Castro Laboreiro; Lamas de Mouro; Melgaço; Parque Nacional da Peneda-Gerês.

\section{Lista de abreviaturas e siglas utilizadas:}

\section{Arquivos}

ADVCT - Arquivo Distrital de Viana do Castelo

SJCLLM - Sede da Junta de Castro Laboreiro e Lamas de Mouro.

\section{Outras siglas}

CGN - Código Geográfico Nacional

E - Este

O - Oeste

$\mathrm{N}$ - Norte

NE - Nordeste

NO - Noroeste

S - Sul

SE - Sudeste

SO - Sudoeste 


\section{Breves apontamentos sobre}

as fichas técnicas de inventário

dos fornos das "invernciras"

de Castro Laborciro
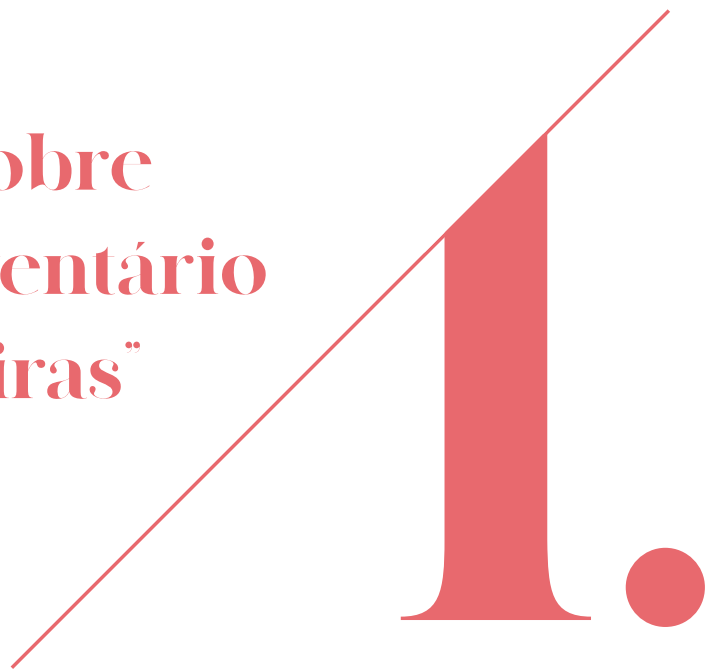

Este segmento do inventário é dedicado aos 21 fornos de pão situados nas "inverneiras"(700-1000mts) de Castro Laboreiro. A contagem inclui os dois fornos demolidos durante o século XX, e também um forno arruinado, dos quais ainda existem memórias coletivas e referências documentais. É um aglomerado servido por duas estradas diferentes e distribuído pelas duas margens do rio, ou seja, é composto por duas sequências. A primeira sequência de fornos está servida pela estrada M1160 e ordenada na margem direita do rio Laboreiro: Laceiras - Ramisqueira - João Alvo - Barreiro - Podre - Assureira - Alagoa - Dorna Entalada. Chegando à aldeia de Entalada é necessário voltar para trás, pela M1160, até ao cruzamento da ponte de Dorna. Aqui, virando à direita, percorre-se a estrada de ligação entre a M1160 e a EN202-3 alcançando Pontes e Mareco, os últimos dois lugares desta sequência. Chegando a este último retoma-se a estrada de ligação em direção à EN202-3, onde encontramos a segunda sequência de lugares, aqueles dispostos na margem esquerda do rio. Chegando à estrada nacional, na fronteira com a Galiza, está o primeiro lugar da segunda sequência: Ameijoeira Bago de Baixo - Bago de Cima - Curveira - Bico - Cainheiras. Em Cainheiras volta-se para trás, seguindo a EN202-3 em direção à Vila de Castro Laboreiro, onde está Varziela, último lugar desta sequência. Contudo, apesar da disposição dos fornos ser esta, para obter uma organização ordenada e de fácil acesso da informação dispuseram-se as fichas de inventário por ordem alfabética (da mesma forma que a "Parte 1"). Relativamente aos campos das fichas que se repetiram de forma sistemática foram também retirados e expostos abaixo. 
O primeiro campo, reservado ao número da ficha, coincide com os subtítulos iniciados em 2.1. O segundo campo, relativo ao nome do responsável pelo preenchimento é o mesmo da autora deste trabalho. Na secção de "Enquadramento administrativo e localização" verifica-se que todos os fornos se localizam no mesmo contexto:

\begin{tabular}{ll}
\hline Concelho & Melgaço \\
\hline Freguesia & Castro Laboreiro \\
\hline CGN & 160302 \\
\hline
\end{tabular}

Na secção "Características gerais", confirma-se que o período de maior atividade de todos estes fornos se enquadra dentro dos seguintes parâmetros:

Época do ano de maior atividade:

De dezembro a março - antes de se tornar num lugar permanentemente, habitado ao longo de ano.

Por força das circunstâncias (emigração e índice baixo de natalidade) muitas das "inverneiras" encontram-se ao abandono, sem residentes, permanentes ou sazonais.

Os conteúdos das notas de campo repetem-se, conforme também ficou explicado na "Parte 1", e sendo as mesmas informações relativamente ao ciclo de cozedura e aspetos culturais.

Relativamente à sua quantidade e distribuição convém mencionar que neste conjunto de aldeias, o lugar de João Alvo não tem forno, e que os lugares de Alagoa, Barreiro e Bago de Baixo têm dois fornos cada, atualmente. Nas "inverneiras" são menos os lugares com fornos múltiplos, em relação ao que acontece nas "brandas", uma consequência natural do curto período de ocupação ao longo do ano e deste período decorrer no inverno, altura em que era mais difícil aquecer e secar as pedras húmidas. 


\section{Fichas técnicas de inventário 18 fornos}
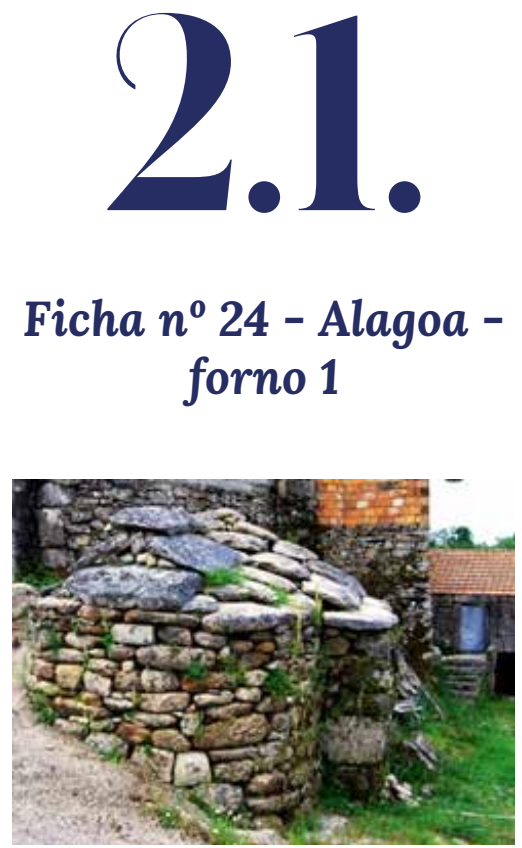

\section{Enquadramento administrativo e localização}

\begin{tabular}{ll}
\hline C.M.P. 1/25000 & $\mathrm{N}^{\circ} 009$ \\
\hline Coordenadas GPS & $41^{\circ}$ 59` 38.2” N8 10’ 15” W \\
\hline Coordenadas decimais & $41.993944,-8.170833$ \\
\hline Acessos & $\begin{array}{l}\text { Estrada municipal. Estrada } \\
\text { secundária. Caminho pedonal. }\end{array}$ \\
\hline Implantação & Terreno desnivelado \\
\hline Confrontações & $\begin{array}{l}\text { Caminho público a S. Terrenos } \\
\text { particulares a N, E e O. }\end{array}$ \\
\hline Elevação & 822 mts \\
\hline Orientação da entrada & $\mathrm{N}$ \\
\hline Proteção existente & Não tem \\
\hline
\end{tabular}

Histórico

Referências documentais e bibliográficas: Não tem.

Registo predial ou urbano: Não tem.

Data de construção: Não há memória.

Periodo de atividade: Memória da última cozedura data de 2010 .

Restauros: Não há memória.

Proprietários: Foi propriedade dos "froucheiros" (alcunha dada a uma família daquele lugar).

Gestores: A comunidade daquele lugar.

Construtores: Não há memória.

Situação atual: Inativo. 
Caracteristicas

Gerais
Técnica construtiva: Pedra aparelhada com preenchimentos em cimento.

Materiais presentes: Granito e cimento.

Capacidade da fornalha: 15 pães.

Produtos confecionados: Pão.

\section{Dimensões}

\begin{tabular}{lllll}
\hline Secções do forno & & Altura & Largura & Prof. \\
\hline Parede lateral (E) & Exterior & Arestas niveladas a $188 \mathrm{~cm}$ & $597 \mathrm{~cm}$ & - \\
\hline Parede frontal (N) & Interior & Arestas niveladas a $194 \mathrm{~cm}$ & $317 \mathrm{~cm}$ & - \\
& Exterior & Aresta à direita $-212 \mathrm{~cm}$ & $430 \mathrm{~cm}$ & - \\
& & Aresta à esquerda $-216 \mathrm{~cm}$ & & \\
& \multirow{2}{*}{ Interior } & Aresta à direita $-200 \mathrm{~cm}$ & $325 \mathrm{~cm}$ & - \\
& & Aresta à esquerda $-132 \mathrm{~cm}$ & & \\
& & Cumieira - $275 \mathrm{~cm}$ & & - \\
\hline Entrada $\mathbf{( N )}$ & & Arestas niveladas a $160 \mathrm{~cm}$ & $91 \mathrm{~cm}$ & $-274 \mathrm{~cm}$ \\
\hline Boca da fornalha $\mathbf{( S )}$ & & Arestas niveladas a $53 \mathrm{~cm}$ & $45 \mathrm{~cm}$ & $168 \mathrm{~cm}$ \\
\hline
\end{tabular}

Análise da Planta: Retangular com abside.

estrutura

Estruturas Cobertura: Duas águas, em lajes de granito.

exteriores Chaminé: Não tem.

Paredes: Parede O encostada a uma elevação de terreno.

Restantes estão destacadas.

Entrada: Entrada orientada a N, de recorte retangular.

Porta: Sem porta.

Estruturas Cobertura: Em lajes de granitos sustentados por um arco de interiores volta perfeita, sendo que o lado O assenta no solo e o lado E está apoiado num bloco de granito. Arquitrave apoiada sobre duas colunas rudimentares compostas por blocos de granito sobrepostos.

Apoios: Um à entrada do forno de cozer. Uma parede E. Paredes: Lisas, sem elementos relevantes de análise.

Saídas de Fumo: Duas. Uma sobranceira à entrada e outra sobranceira à boca da fornalha.

Janelas: Uma estrutura tapada no interior que parece ter sido uma janela, na parede E. 
Chaminé: Não tem. A saída do fumo processa-se por pequenos orifícios, um em cada canto da junção da parede do forno de cozer com as paredes E e O.

Fornalha: Orientado a S. Entrada de recorte quadrangular. Interior em cúpula de granito.

Porta da fornalha: Porta original do forno de cozer em granito $48 \mathrm{~cm}$ largura e $43 \mathrm{~cm}$ de altura com cruz gravada em baixo relevo de $22 \mathrm{~cm} \times 16 \mathrm{~cm}$, a meio da porta.

\section{Notas de campo e informações adicionais:}

Informações prestadas no dia em 12/11/2014, por Braselina Fernandes (78 anos), residente no Lugar da Vila:

Não há memória deste forno ter dado abrigo a "mendigos ou latoeiros", uma vez que este se encontra dentro de uma propriedade privada. 

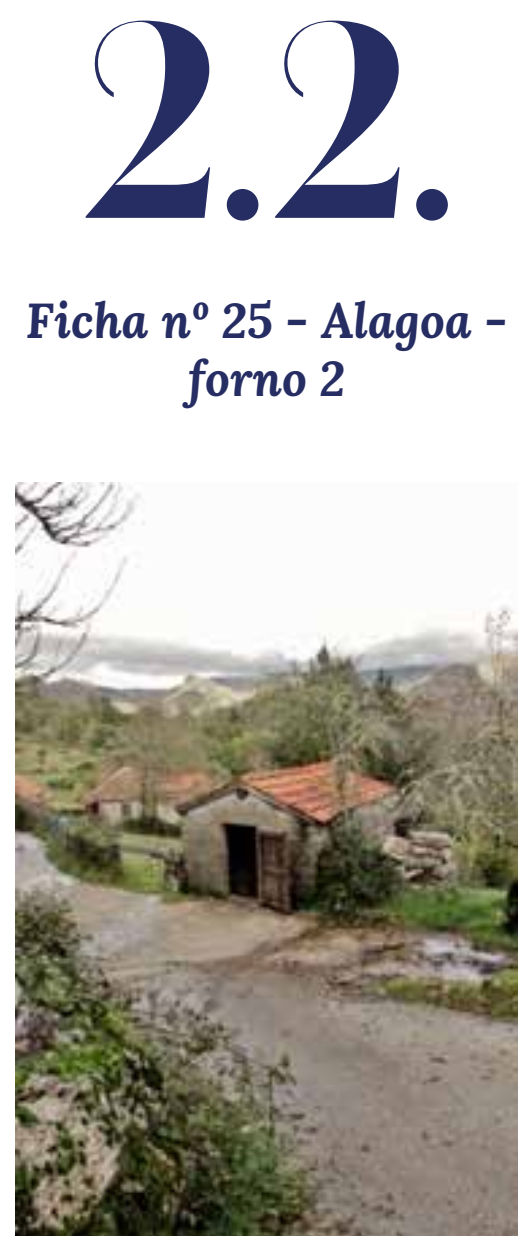

\section{Dimensões}

\begin{tabular}{lllll}
\hline Secções do forno & & Altura & Largura & Prof. \\
\hline & Exterior & Aresta à direita $-178 \mathrm{~cm}$ & $470 \mathrm{~cm}$ & \\
& Aresta à esquerda $-272 \mathrm{~cm}$ & & \\
& & & \\
\hline
\end{tabular}

\section{Enquadramento administrativo e localização}

\begin{tabular}{ll}
\hline C.M.P. 1/25000 & $\mathrm{N}^{\circ} 009$ \\
\hline Coordenadas GPS & $41^{\circ} 59^{\prime} 37.4^{\prime \prime} \mathrm{N} 8^{\circ} 10^{\prime} 16.3^{\prime \prime} \mathrm{W}$ \\
\hline Coordenadas decimais & $41.993722,-8.171194$ \\
\hline Acessos & $\begin{array}{l}\text { Estrada Municipal e Estrada } \\
\text { Secundária }\end{array}$ \\
\hline Implantação & Terreno desnivelado \\
\hline & $\begin{array}{l}\text { Confronta com caminho e } \\
\text { fontanário público a O. Confronta } \\
\text { com terrenos particulares a E, S e N }\end{array}$ \\
\hline Elevaçãos & $860 \mathrm{mts}$ \\
\hline Orientação da entrada & $\mathrm{O}$ \\
\hline Proteção existente & Não tem \\
\hline
\end{tabular}

\section{Histórico}

Referências documentais e bibliográficas: Não tem

Registo predial ou urbano: Não tem. Data de construção: Não há memória. Período de atividade: Última cozedura data de 2013.

Restauros: Restauro data da década de 70. Proprietários: Foi propriedade dos "Galhardos" (Alcunha dada a uma família daquele lugar).

Gestores: A comunidade daquele lugar.

Construtores: Não há memória.

Situação atual: Ativo.

Características Técnica construtiva: Pedra e blocos de Gerais cimento aparelhados com preenchimentos e revestimentos em cimento.

Materiais presentes: Cimento, telha, granito, madeira, poliuretano.

Capacidade da fornalha: 9 pães.

Produtos confecionados: Pão. Carne (em dias festivos). 


\begin{tabular}{|c|c|c|c|c|}
\hline \multirow[t]{5}{*}{ Parede lateral (N) } & Interior & Aresta à direita $-65 \mathrm{~cm}$ & $415 \mathrm{~cm}$ & \\
\hline & & Aresta à esquerda $-202 \mathrm{~cm}$ & & \\
\hline & Exterior & Aresta à direita $-178 \mathrm{~cm}$ & $320 \mathrm{~cm}$ & \\
\hline & & Aresta à esquerda - 178cm & & \\
\hline & & Cumieira $-237 \mathrm{~cm}$ & & \\
\hline \multirow[t]{3}{*}{ Parede frontal (0) } & Interior & Aresta à direita $-202 \mathrm{~cm}$ & $279 \mathrm{~cm}$ & \\
\hline & & Aresta à esquerda - $215 \mathrm{~cm}$ & & \\
\hline & & Cumieira -270cm & & \\
\hline Entrada (O) & & Arestas niveladas a $152 \mathrm{~cm}$ & $87 \mathrm{~cm}$ & \\
\hline Boca da fornalha (E) & & Arestas niveladas a $54 \mathrm{~cm}$ & $52 \mathrm{~cm}$ & $130 \mathrm{~cm}$ \\
\hline
\end{tabular}

Análise da Planta: Retangular.

estrutura

Estruturas Cobertura: Duas águas, em telha.

exteriores Chaminé: Não tem.

Paredes: Parede N e S em parte constituídas por blocos de cimento e pela estrutura original em granito, nas traseiras. Parede O totalmente em blocos de cimento. Parede S tem estrutura em granito, terminando na parte superior com blocos de cimento.

Entrada: Retangular, orientada a O.

Porta: Em madeira.

Estruturas Cobertura: Em telha, suportado por vigas e traves de madeira, interiores com revestimentos a cimentos e pedras.

Apoios: Um em frente à fornalha.

Paredes: Compostas por blocos de cimento. São lisas sobrando unicamente uma pedra de granito na junção inferior das paredes O e S, e no degrau da entrada.

Saídas de Fumo: Não tem.

Janelas: Não tem.

Chaminé: Não tem.

Fornalha: Orientado a E. Entrada de recorte quadrangular. Interior em cúpula, revestida a tijolo refratário.

Porta da fornalha: Em metal. Abre em duas partes.

\section{Notas de campo e informações adicionais:}

Informações prestadas no dia 12/11/2014, por Braselina Fernandes (78 anos), residente no Lugar da Vila:

Forno originalmente em pedra. Tinha chave. 


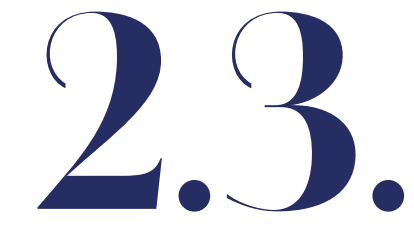

Ficha $n^{0} 26$ Ameijoeira

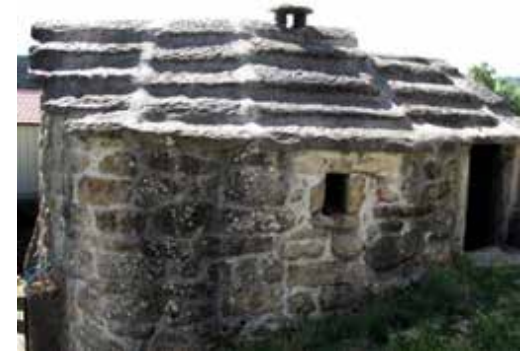

\section{Enquadramento administrativo e localização}

\begin{tabular}{|c|c|}
\hline C.M.P. $1 / 25000$ & $\mathrm{~N}^{\circ} 009$ \\
\hline Coordenadas GPS & $41^{\circ} 59^{`} 9.4^{\prime \prime} \mathrm{N} 8^{\circ} 9^{\prime} 28.1^{\prime \prime} \mathrm{W}$ \\
\hline Coordenadas decimais & $41.985944,-8.157806$ \\
\hline Acessos & Estrada nacional. \\
\hline Implantação & Terreno desnivelado \\
\hline Confrontações & $\begin{array}{l}\text { Caminho público a } \mathrm{N} \text { e E. } \\
\text { Terrenos particulares a } \mathrm{O} \text { e } \mathrm{S}\end{array}$ \\
\hline Elevação & $776 \mathrm{mts}$ \\
\hline Orientação da entrada & $\mathrm{E}$ \\
\hline Proteção existente & Não tem \\
\hline
\end{tabular}

Histórico

Referências documentais e bibliográficas: Livro de Atas de 2003-2011 - data de 5/4/2008.

Registo predial ou urbano: Não tem. Data de construção: Não há memória. Periodo de atividade: Regular.

Restauros: Anterior a 2008 houve um restauro datado de 1954/64, no qual se elevou a cobertura.

Proprietários: Não tem.

Gestores: A comunidade daquele lugar. Construtores: Não há memória.

Situação atual: Ativo.

Características Técnica construtiva: Pedra aparelhada Gerais com revestimentos e preenchimentos em cimento.

Materiais presentes: Granito, cimento. Capacidade da fornalha: 20 pães.

Produtos confecionados: Pão. Carne.

\section{Dimensões}

\begin{tabular}{lllll}
\hline Secções do forno & Altura & Largura & Prof. \\
\hline & Exterior & Aresta à esquerda $-125 \mathrm{~cm}$ & $506 \mathrm{~cm}$ & - \\
& & & \\
& & Aresta à direita $-218 \mathrm{~cm}$ & & \\
& & & \\
& & Cumieira $-295 \mathrm{~cm}$ & \\
\hline Parede lateral (N) & Interior & Aresta à direita $-172 \mathrm{~cm}$ & $385 \mathrm{~cm}$ & - \\
& & Aresta à esquerda $-194 \mathrm{~cm}$ & &
\end{tabular}




\begin{tabular}{lllll} 
& & & Cumieira $-280 \mathrm{~cm}$ & \\
& Exterior & Aresta à direita $-155 \mathrm{~cm}$ & $440 \mathrm{~cm}$ & - \\
& & & \\
& & Aresta à esquerda $-242 \mathrm{~cm}$ & & \\
\hline Parede frontal $(\mathbf{E})$ & Interior & Aresta à direita $-198 \mathrm{~cm}$ & $310 \mathrm{~cm}$ & - \\
& & Aresta à esquerda $-180 \mathrm{~cm}$ & & \\
\hline Entrada $(\mathbf{E})$ & & Arestas niveladas a $160 \mathrm{~cm}$ & $101 \mathrm{~cm}$ & - \\
\hline Boca da fornalha $(\mathbf{S})$ & Arestas niveladas a $52 \mathrm{~cm}$ & $53 \mathrm{~cm}$ & $170 \mathrm{~cm}$ \\
\hline
\end{tabular}

Análise da Planta: Retangular com cabeceira.

estrutura

Estruturas Cobertura: Telhado de duas águas.

exteriores Chaminé: Chaminé em granito, ao centro da cobertura, composta por 3 lajes quadrangulares.

Paredes: Parede S ovalada. Parede O ocupa um terreno privado. Parede N é lisa.

Entrada: Entrada orientada a E, retangular, com um banco adossado do lado direito.

Porta: Porta em metal.

Estruturas Cobertura: Em lajes de granito, sustentado por três estruturas interiores triangulares compostas por esteios de granito, um a meio da estrutura, outro acima da fornalha e outro a S, assentando em blocos de granito sobrepostos.

Apoios: Um na parede O entre dois balcões. Corrido a toda a volta exceto na parede $\mathrm{E}$, reconstruídos em cimento.

Paredes: Existe uma reentrância na pedra da parede E. Coluna de suporte do arco principal na parede $\mathrm{O}$.

Saídas de Fumo: Uma saída de fumo na parede N e outra diretamente acima do forno de cozer.

Janelas: Uma na parede E.

Chaminé: Não tem. Existe apenas uma saída de fumo acima da fornalha.

Fornalha: Orientada a S, entrada de recorte quadrangular. Interior em cúpula revestida a tijolo.

Porta da fornalha: Quadrangular, em metal.

\section{Notas de campo e informações adicionais:}

Assava-se carne no dia da romaria do lugar. 

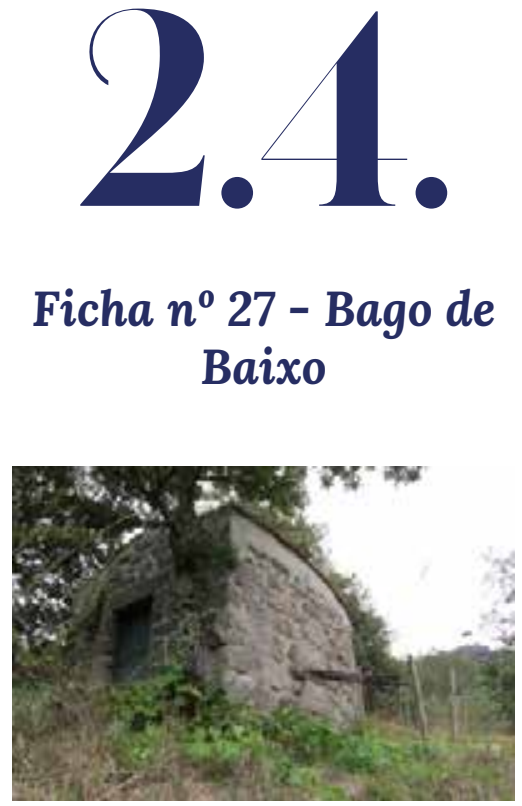

Histórico

Características Gerais

\section{Enquadramento administrativo e localização}

\begin{tabular}{ll}
\hline C.M.P. 1/25000 & $\mathrm{N}^{\circ} 009$ \\
\hline Coordenadas GPS & $41^{\circ} 59^{\prime} 44.8^{\prime \prime}$ N 8 9' 33.5” W \\
\hline Coordenadas decimais & $41.995778,-8.159306$ \\
\hline Acessos & $\begin{array}{l}\text { Estrada nacional, Estrada } \\
\text { secundária e Caminho pedonal. }\end{array}$ \\
\hline Implantação & Terreno desnivelado \\
\hline Confrontações & $\begin{array}{l}\text { Terrenos baldios a O, E, N e S. } \\
\text { Mina de água a O. }\end{array}$ \\
\hline Elevação & $767 \mathrm{mts}$ \\
\hline Orientação da entrada & $\mathrm{O}$ \\
\hline Proteção existente & Não tem \\
\hline
\end{tabular}

Referências documentais e bibliográficas: Não tem.

Registo predial ou urbano: Não tem.

Data de construção: Não há memória.

Período de atividade: Memória da última cozedura data de 2007.

Restauros: Restauro data de 2005 ou 2006.

Proprietários: Não tem.

Gestores: A comunidade daquele lugar.

Construtores: Não há memória.

Situação atual: Inativo.

Técnica construtiva: Pedra aparelhada com revestimentos e preenchimentos em cimento.

Materiais presentes: Granito, cimento, telha e madeira.

Capacidade da fornalha: 20 pães.

Produtos confecionados: Pão.

\section{Dimensões}

\begin{tabular}{lllll}
\hline Secções do forno & & Altura & Largura & Prof. \\
\hline & Exterior & Aresta à esquerda $-338 \mathrm{~cm}$ & $732 \mathrm{~cm}$ & - \\
& & Aresta à direita- $188 \mathrm{~cm}$ & & \\
\hline Parede lateral (S) & Interior & $\begin{array}{l}\text { Aresta à esquerda }-244 \mathrm{~cm} \\
\text { Aresta à direita }-283 \mathrm{~cm}\end{array}$ & $373 \mathrm{~cm}$ & - \\
& & Aresta à direita- $338 \mathrm{~cm}$ & $362 \mathrm{~cm}$ & -
\end{tabular}


Aresta à esquerda $-227 \mathrm{~cm}$

Cumieira - 358cm

\begin{tabular}{|c|c|c|c|c|}
\hline Parede frontal (0) & Interior & $\begin{array}{l}\text { Aresta à esquerda }-283 \mathrm{~cm} \\
\text { Aresta à direita }-261 \mathrm{~cm} \\
\text { Cumieira }-315 \mathrm{~cm}\end{array}$ & $264 \mathrm{~cm}$ & - \\
\hline Entrada (0) & & $184 \mathrm{~cm}$ & $100 \mathrm{~cm}$ & - \\
\hline Boca da fornalha (E) & & $49 \mathrm{~cm}$ & $51 \mathrm{~cm}$ & $152 \mathrm{~cm}$ \\
\hline
\end{tabular}

Análise da Planta: Retangular com cabeceira.

estrutura

Estruturas Cobertura: Telhado de duas águas, em telha.

exteriores Chaminé: Não tem.

Paredes: Parede E e N encontram-se cobertas de terra e vegetação até ao nível da telha. A parede $\mathrm{N}$ tem um lance de escadas adossado. Parede $\mathrm{S}$ ligeiramente ovalada e as restantes lisas.

Entrada: Orientada a O, de recorte retangular.

Porta: Em metal.

Estruturas Cobertura: Em telha, suportado por vigas e traves de madeira.

interiores Apoios: Um na parede N, em cimento, apoiado em duas colunas de blocos de cimento sobrepostos. Uma parede E. A parede S apresenta dois blocos de granito salientes da parede, a cerca de $40 \mathrm{~cm}$ do chão, independentes, (talvez sejam vestígios de uma estrutura anterior, e tenham sido aproveitados como dois bancos ou apoios).

Paredes: Parede S e parede N terminam numa fila de blocos de cimento cada uma, onde assenta a cobertura. Lisas, sem elementos relevantes de análise. Uma das pedras da parede E, no canto inferior esquerdo, está bastante desgastada e tem uma textura suave e alisada, que se destaca de todas as outras.

Saídas de Fumo: Não tem.

Janelas: Não tem.

Chaminé: Existem duas lajes quadrangulares de granito, unidas e colocadas na horizontal, criando uma "pala" sobre o forno de cozer. Fornalha: Orientado a Este, de entrada quadrangular. Interior em cúpula, revestida a tijolo refratário.

Porta da fornalha: Em metal.

\section{Notas de campo e informações adicionais:}

Informações prestadas por Aurora Alves (72 anos), no dia 4/8/2014:

Cobertura original em granito. 


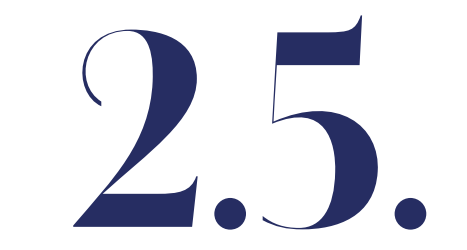

Ficha $n^{0} 28$ - Bago de Cima

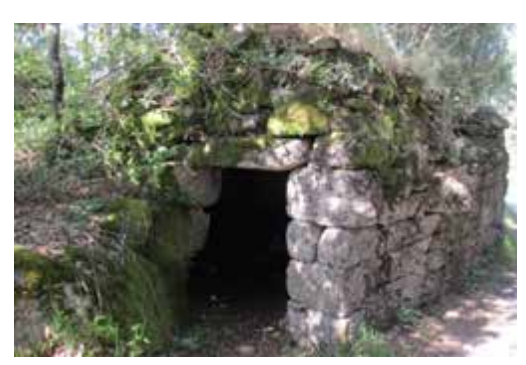

\section{Enquadramento administrativo e localização}

\begin{tabular}{ll}
\hline C.M.P. 1/25000 & $\mathrm{N}^{\circ} 009$ \\
\hline Coordenadas GPS & $42^{\circ}$ 0` 2.2" N 8 9` 27” W \\
\hline Coordenadas decimais & $42.000611,-8.157500$ \\
\hline Acessos & $\begin{array}{l}\text { Estrada nacional e Estrada } \\
\text { secundária. }\end{array}$ \\
\hline Implantação & Terreno desnivelado. \\
\hline Confrontações & $\begin{array}{l}\text { Caminho público a E, O e S. Fontário } \\
\text { público a O. Terreno baldio a N. }\end{array}$ \\
\hline Elevação & $815 \mathrm{mts}$ \\
\hline Orientação da entrada & $\mathrm{O}$ \\
\hline Proteção existente & Não tem \\
\hline
\end{tabular}

Histórico

Referências documentais e bibliográficas: Não tem.

Registo predial ou urbano: Não tem.

Data de construção: Não há memória.

Periodo de atividade: Memória da última cozedura data da década de 80 .

Restauros: Não há memória de ter sido restaurado.

Proprietários: Não tem.

Gestores: A comunidade daquele lugar.

Construtores: Não há memória.

Situação atual: Inativo.

Características Técnica construtiva: Pedra aparelhada.

Gerais
Materiais presentes: Granito.

Capacidade da fornalha: 13 pães.

Produtos confecionados: Pão.

\section{Dimensões}

\begin{tabular}{lllll}
\hline Secções do forno & & Altura & Largura & Prof. \\
\hline & Exterior & Arestas niveladas a $216 \mathrm{~cm}$ & $482 \mathrm{~cm}$ & - \\
\hline Parede lateral $(\mathbf{S})$ & Interior & Arestas niveladas a $200 \mathrm{~cm}$ & $305 \mathrm{~cm}$ & - \\
& Exterior & Aresta à direita $-243 \mathrm{~cm}$ & $257 \mathrm{~cm}$ & - \\
& & Aresta à esquerda $-100 \mathrm{~cm}$ & & \\
& & Cumieira - $290 \mathrm{~cm}$ & - \\
\hline Parede frontal $(\mathbf{O})$ & Interior & Aresta à esquerda $-180 \mathrm{~cm}$ & $274 \mathrm{~cm}$ & \\
& & Aresta à direita $-165 \mathrm{~cm}$ & &
\end{tabular}


Cumieira $-196 \mathrm{~cm}$

\begin{tabular}{llll}
\hline Entrada (O) & Arestas niveladas a $157 \mathrm{~cm}$ & $93 \mathrm{~cm}$ & - \\
\hline Boca da fornalha $(\mathbf{E})$ & Arestas niveladas a $90 \mathrm{~cm}$ & $43 \mathrm{~cm}$ & $140 \mathrm{~cm}$ \\
\hline
\end{tabular}

Análise da Planta: Retangular com cabeceira.

estrutura

Estruturas Cobertura: Telhado de duas águas, em lajes de granito.

exteriores Chaminé: Não tem.

Paredes: Parede N encostada a uma elevação de terreno. Parede

Sem estado de ruína.

Entrada: Orientada a O. Recorte irregular.

Porta: Sem porta.

Estruturas Cobertura: Em lajes de granito, suportado por uma estrutura interiores triangular composta por esteios de granito, que repousam numa pedra de fecho, assentes em dois cachorros.

Apoios: Um em frente à fornalha. Um na parede S, seguido de dois bancos individuais.

Paredes: Sem elementos relevantes de análise.

Saídas de Fumo: Saída de fumo acima da boca da fornalha.

Janelas: Janela na parede N, tapada pela elevação de terreno.

Chaminé: Não tem.

Fornalha: Orientado a E, de recorte quadrangular.

Porta da fornalha: Sem porta.

\section{Notas de campo e informações adicionais:}

Não se encontraram membros residentes neste lugar. Algumas das informações foram obtidas em conversa com a Professora Áurea, residente na Vila. 


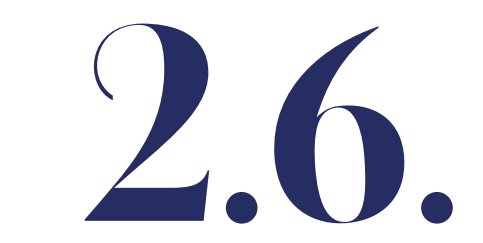

Ficha $n^{0} 29$ - Barreiro - forno 1

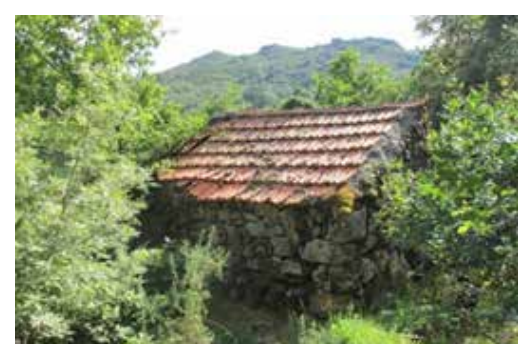

\section{Histórico}

Características Gerais

\section{Enquadramento administrativo e localização}

\begin{tabular}{ll}
\hline C.M.P. 1/25000 & $\mathrm{N}^{\circ} 009$ \\
\hline Coordenadas GPS & $42^{\circ} 0^{\prime}$ 35.6” N 8 10`17.1” W \\
\hline Coordenadas decimais & $42.009889,-8.171417$ \\
\hline Acessos & $\begin{array}{l}\text { Estrada municipal. } \\
\text { Estrada secundária. }\end{array}$ \\
\hline Implantação & Terreno desnivelado. \\
\hline & $\begin{array}{l}\text { Caminho público a O. Terrenos } \\
\text { Confrontações }\end{array}$ \\
\hline Elevação & 832mts a N, S e E. \\
\hline Orientação da entrada & $\mathrm{N}$ \\
\hline Proteção existente & Não tem \\
\hline
\end{tabular}

Referências documentais e bibliográficas: Não tem.

Registo predial ou urbano: Não tem.

Data de construção: Não há memória.

Período de atividade: Memória da última cozedura data de 2001

Restauros: Restauro data de 1984.

Proprietários: Considerado de herdeiros.

Gestores: A comunidade daquele lugar.

Construtores: Não há memória.

Situação atual: Inativo.

Técnica construtiva: Pedra aparelhada com revestimentos e preenchimentos a cimento. Materiais presentes: Granito, cimento, telha e madeira.

Capacidade da fornalha: 7 broas.

Produtos confecionados: Pão.

\section{Dimensões}

\begin{tabular}{lllll}
\hline Secções do forno & & Altura & Largura & Prof. \\
\hline & Exterior & Arestas niveladas a $170 \mathrm{~cm}$ & $500 \mathrm{~cm}$ & - \\
\hline Parede lateral (O) & Interior & Arestas niveladas a $176 \mathrm{~cm}$ & $250 \mathrm{~cm}$ & - \\
& Exterior & Arestas niveladas a $270 \mathrm{~cm}$ & $390 \mathrm{~cm}$ & \\
\hline Parede frontal (N) & Interior & Aresta à direita $-193 \mathrm{~cm}$ & $278 \mathrm{~cm}$ & - \\
& & Aresta à esquerda $-174 \mathrm{~cm}$ & & \\
& & Cumieira $-248 \mathrm{~cm}$ & & \\
& &
\end{tabular}




\begin{tabular}{llll} 
Entrada $(\mathbf{N})$ & Arestas niveladas a $180 \mathrm{~cm}$ & $390 \mathrm{~cm}$ & - \\
\hline Boca da fornalha $(\mathbf{S})$ & Arestas niveladas a $43 \mathrm{~cm}$ & $49 \mathrm{~cm}$ & $120 \mathrm{~cm}$ \\
\hline
\end{tabular}

Análise da Planta: Retangular com cabeceira. estrutura

Estruturas Cobertura: Duas águas, em telha. Cobertura em estado de ruína. exteriores Chaminé: Não tem.

Paredes: Parede O assenta sobre uma afloração granítica. Parede $\mathrm{S}$ apresenta graves sinais de degradação.

Entrada: Orientada a N, de recorte retangular.

Porta: Sem porta.

Estruturas Cobertura: Em telha, suportado por vigas e traves de madeira. interiores Apoios: Um em frente à fornalha, composto por lajes de granito irregulares.

Paredes: Sem elementos relevantes de análise.

Saídas de Fumo: Não tem.

Janelas: Não tem.

Chaminé: Acima do forno de cozer, suportada por dois cachorros, em granito.

Fornalha: Orientado a S, de recorte quadrangular. Interior em cúpula.

Porta da fornalha: Não tem.

\section{Notas de campo e informações adicionais:}

Informações prestadas no dia 12/11/2014, por Domingos Pires e esposa, residentes em Adofreire: Era utilizado pelos habitantes do lugar de cima, no Barreiro, embora se considere objeto de herança. 


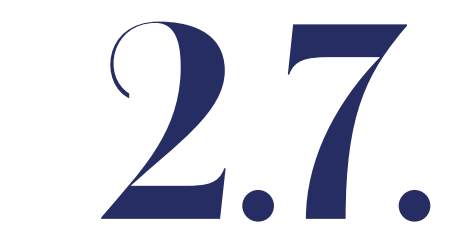

Ficha $n^{0} 30$ - Barreiro - forno 2

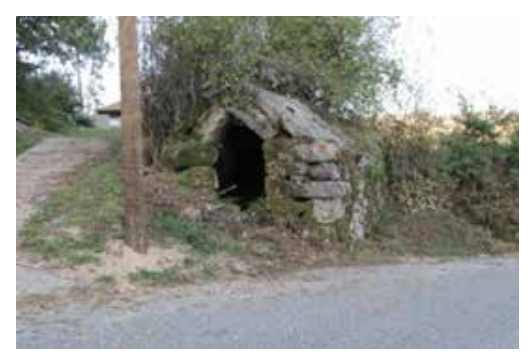

\section{Enquadramento administrativo e localização}

\begin{tabular}{ll}
\hline C.M.P. 1/25000 & $\mathrm{N}^{\circ} 009$ \\
\hline Coordenadas GPS & $42^{\circ} 0^{\prime}$ 34.5” N 8 10' 11.7” W \\
\hline Coordenadas decimais & $42.009583,-8.169917$ \\
\hline Acessos & $\begin{array}{l}\text { Estrada nacional. } \\
\text { Estrada secundária. }\end{array}$ \\
\hline Implantação & Terreno desnivelado \\
\hline Confrontações & Caminho público a O, N e S. \\
\hline Elevação & Terreno particular a E. \\
\hline Orientação da entrada & O08mts. \\
\hline Proteção existente & Não tem \\
\hline
\end{tabular}

\section{Histórico}

Referências documentais e bibliográficas: Não tem.

Registo predial ou urbano: Não tem.

Data de construção: Não há memória.

Período de atividade: Memória da última cozedura data de 1984.

Restauros: Não há memória.

Proprietários: Não tem.

Gestores: A comunidade daquele lugar.

Construtores: Não há memória.

Situação atual: Inativo.

Caracteristicas Técnica construtiva: Pedra aparelhada Gerais com revestimentos e preenchimentos em cimento.

Materiais presentes: Granito e cimento. Capacidade da fornalha: 8 pães. Produtos confecionados: Pão.

\section{Dimensões}

\begin{tabular}{lllll}
\hline Secções do forno & & Altura & Largura & Prof. \\
\hline & Exterior & Arestas niveladas a $180 \mathrm{~cm}$ & $330 \mathrm{~cm}$ & - \\
\hline Parede lateral (S) & Interior & Arestas niveladas a $130 \mathrm{~cm}$ & $320 \mathrm{~cm}$ & - \\
& Exterior & Arestas niveladas: $180 \mathrm{~cm}$ & $340 \mathrm{~cm}$ & - \\
& & Cumieira: $250 \mathrm{~cm}$ & & \\
\hline Parede frontal (0) & Interior & Arestas niveladas: $1,47 \mathrm{~m}$ & $230 \mathrm{~cm}$ & - \\
& & Cumieira: $2,29 \mathrm{~m}$ & & \\
\hline
\end{tabular}




\begin{tabular}{llll} 
Entrada $(\mathbf{O})$ & Arestas niveladas: $185 \mathrm{~cm}$ & $100 \mathrm{~cm}$ & - \\
\hline Boca da fornalha $(\mathbf{E})$ & Arestas niveladas: $50 \mathrm{~cm}$ & $48 \mathrm{~cm}$ & $140 \mathrm{~cm}$ \\
\hline
\end{tabular}

Análise da Planta: Retangular com cabeceira.

estrutura

Estruturas Cobertura: Telhado de duas águas, composto por lajes de granito, exteriores com "remendos" de cimento.

Chaminé: Não tem ou está oculta

Paredes: Parede N encostada a uma elevação de terreno.

Entrada: Entrada orientada a O, retangular com topo triangular composto por dois esteios.

Porta: Não tem.

Estruturas Cobertura: Teto suportado por duas estruturas triangulares interiores compostas por esteios que se distribuem na diagonal e assentam em blocos de pedra. A estrutura mais próxima da entrada repousa, no topo, numa pedra de fecho.

Apoios: Bancos corridos nas paredes N e S, balcão corrido em frente à fornalha.

Paredes: Existe uma reentrância na estrutura, um nicho, na parede S.

Saídas de Fumo: Não tem.

Janelas: Não tem.

Chaminé: Acima da entrada do forno de cozer, suportada por dois cachorros. Toda esta estrutura é em pedra.

Fornalha: Forno de cozer orientado a E, entrada de recorte quadrangular. Interior em cúpula revestida a tijolo.

Porta da fornalha: Não tem.

\section{Notas de campo e informações adicionais:}

Informações prestadas no dia 12/11/2014, por Maria de Fátima Rodrigues e Albertino Domingues (cerca de 60 anos), residentes no Rodeiro:

Este forno carecia de muita lenha para aquecer (cerca de um carro de bois), uma vez que as suas pedras concentravam muita humidade. Afirmam que os seus antepassados já tinham o mesmo problema, um forno difícil de aquecer e o pão nunca ficava bem cozido. 


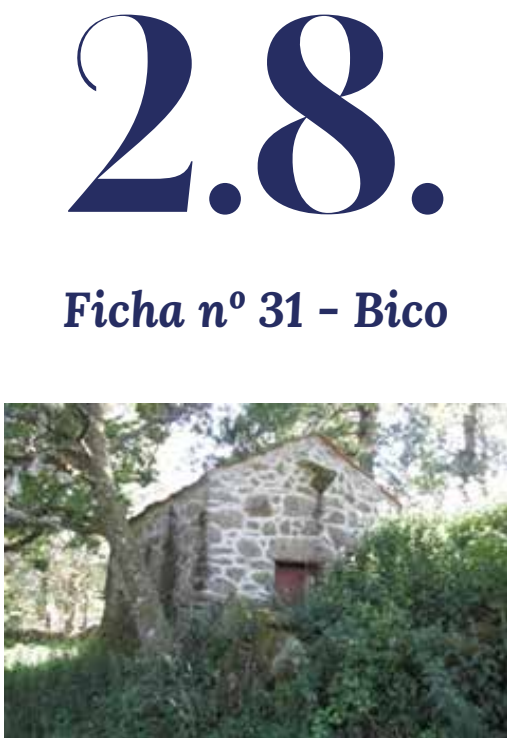

\section{Enquadramento administrativo e localização}

\begin{tabular}{ll}
\hline C.M.P. 1/25000 & $\mathrm{N}^{\circ} 004$ \\
\hline Coordenadas GPS & $42^{\circ} 1^{\prime} 14.1$ I N $^{\circ}$ 8 $^{\prime}$ 43.6” W \\
\hline Coordenadas decimais & $42.020583,-8.145444$ \\
\hline Acessos & $\begin{array}{l}\text { Estrada nacional. Estrada } \\
\text { secundária. Caminho pedonal. }\end{array}$ \\
\hline Implantação & Terreno desnivelado \\
\hline Confrontações & $\begin{array}{l}\text { Caminho público a N. Terrenos } \\
\text { particulares a S, E e O. }\end{array}$ \\
\hline Elevação & $952 \mathrm{mts}$ \\
\hline Orientação da entrada & $\mathrm{N}$ \\
\hline Proteção existente & Não tem \\
\hline
\end{tabular}

Histórico

Referências documentais e bibliográficas:

Livro de Atas de 2003-2011 - ata de $6 / 5 / 2006$.

Registo predial ou urbano: Não tem.

Data de construção: Não há memória.

Período de atividade: Regular.

Restauros: Restauro em 2006.

Proprietários: Não tem.

Gestores: A comunidade deste lugar.

Construtores: Não há memória.

Situação atual: Ativo.

Características Técnica construtiva: Pedra aparelhada Gerais com revestimentos e preenchimentos em cimento.

Materiais presentes: Granito, cimento, telha e madeira.

Capacidade da fornalha: 15 pães.

Produtos confecionados: Pão.

\section{Dimensões}

\begin{tabular}{lllll}
\hline Secções do forno & & Altura & Largura & Prof. \\
\hline & Exterior & Aresta à esquerda $-330 \mathrm{~cm}$ & $516 \mathrm{~cm}$ & - \\
& & Aresta à direita $-346 \mathrm{~cm}$ & & \\
\hline Parede lateral (E) & Interior & Aresta à direita $-248 \mathrm{~cm}$ & $389 \mathrm{~cm}$ & - \\
& & Aresta à esquerda $-297 \mathrm{~cm}$ & & \\
& & & $339 \mathrm{~cm}$ & -
\end{tabular}


Aresta à esquerda $-346 \mathrm{~cm}$

Cumieira - 354cm

\begin{tabular}{lllll}
\hline Parede frontal (N) & Interior & Aresta à direita $-297 \mathrm{~cm}$ & $291 \mathrm{~cm}$ & - \\
& Aresta à esquerda $-309 \mathrm{~cm}$ & & \\
& Cumieira $-397 \mathrm{~cm}$ & & \\
\hline Entrada $(\mathbf{N})$ & Arestas niveladas a $144 \mathrm{~cm}$ & $91 \mathrm{~cm}$ & - \\
\hline Boca da fornalha $(\mathbf{S E})$ & Arestas niveladas a $51 \mathrm{~cm}$ & $45 \mathrm{~cm}$ & $160 \mathrm{~cm}$ \\
\hline
\end{tabular}

Análise da Planta: Retangular com cabeceira.

estrutura

Estruturas Cobertura: Telhado de duas águas, em telha.

exteriores Chaminé: Não tem.

Paredes: Parede E tem uma janela profunda. Restantes paredes sem elementos relevantes de análise.

Entrada: Entrada orientada a N de recorte retangular. Detalhe de uma estrutura arquitetónica retangular, encimada à porta (possivelmente de uma estrutura anterior à do atual forno). Porta: De metal.

Estruturas interiores
Cobertura: Telha, suportada por vigas e traves de madeira, com chapas de metal a remendar partes da cobertura.

Apoios: Existem em redor do forno, restaurados em cimento, exceto na parede $\mathrm{N}$. A bancada entre a parede $\mathrm{S}$ e $\mathrm{O}$ faz um ângulo. Compartimento/reentrância por baixo da bancada da parede E.

Paredes: Todas as paredes são de estrutura irregular, exceto a parede $\mathrm{N}$ que é reta. Lisas sem elementos relevantes.

Saidas de Fumo: Não tem.

Janelas: Uma na parede E.

Chaminé: Dois cachorros suportam uma placa em tijolos, ligeiramente arqueada, pousada na horizontal.

Fornalha: Orientada a SE, entrada de recorte quadrangular. Interior em cúpula, revestida a tijolo refratário.

Porta da fornalha: Em metal.

\section{Notas de campo e informações adicionais:}

Informações prestadas por Leonor Rodrigues, residente em Padresouro:

Cobertura original em pedra. 


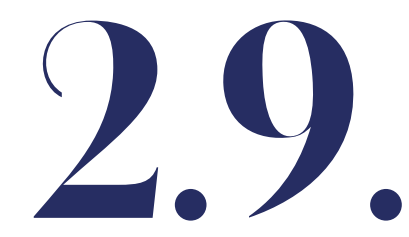

Ficha $n^{0} 32$ Cainheiras

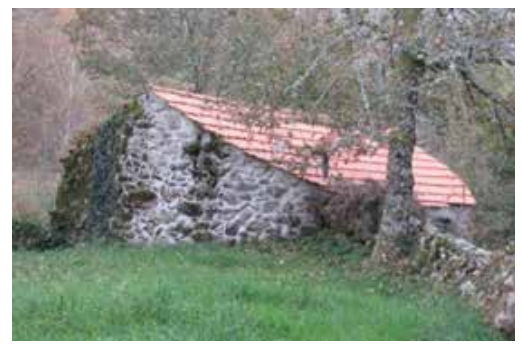

\section{Enquadramento administrativo e localização}

\begin{tabular}{|c|c|}
\hline C.M.P. 1/25000 & $\mathrm{N}^{\circ} 004$ \\
\hline Coordenadas GPS & $42^{\circ} 1^{\prime} 28.6^{\prime \prime} \mathrm{N} 8^{\circ} 8^{\prime} 25.3^{\prime \prime} \mathrm{W}$ \\
\hline Coordenadas decimais & 42.024611, -8.140361 \\
\hline Acessos & $\begin{array}{l}\text { Estrada nacional. Estrada } \\
\text { secundária. Caminho pedonal. }\end{array}$ \\
\hline Implantação & Terreno desnivelado \\
\hline Confrontações & $\begin{array}{l}\text { Caminho público a O e S. Terrenos } \\
\text { particulares a E e N. }\end{array}$ \\
\hline Elevação & $992 \mathrm{mts}$ \\
\hline Orientação da entrada & $\mathrm{O}$ \\
\hline Proteção existente & Não tem \\
\hline
\end{tabular}

Referências documentais e bibliográficas: Livro de Atas de 2003-2011 - ata de $4 / 4 / 2004$.

Livro de Atas da extinta Câmara de Castro Laboreiro de 1842 a 1849 - ata de 31/5/1844. Registo predial ou urbano: Não tem. Data de construção: Não há memória. Período de atividade: Regular. Restauros: Restauro em 2004.

Proprietários: Não tem.

Gestores: A comunidade daquele lugar. Construtores: Não há memória. Situação atual: Ativo.

Características Técnica construtiva: Pedra aparelhada Gerais com revestimentos e preenchimentos em cimento.

Materiais presentes: Granito, cimento, telha e madeira.

Capacidade da fornalha: 20 pães.

Produtos confecionados: Pão.

\section{Dimensões}

\begin{tabular}{lllll}
\hline Secções do forno & Altura & Largura & Prof. \\
\hline & Exterior & Aresta à esquerda $-195 \mathrm{~cm}$ & $650 \mathrm{~cm}$ & - \\
& & & \\
& Aresta à direita $-283 \mathrm{~cm}$ & & \\
& Cumieira $-410 \mathrm{~cm}$ & & \\
\hline
\end{tabular}




\begin{tabular}{|c|c|c|c|c|}
\hline Parede lateral (S) & Interior & $\begin{array}{l}\text { Aresta à esquerda }-253 \mathrm{~cm} \\
\text { Aresta à direita }-255 \mathrm{~cm} \\
\text { Cumieira }-315 \mathrm{~cm}\end{array}$ & $463 \mathrm{~cm}$ & - \\
\hline & Exterior & Arestas niveladas a $194 \mathrm{~cm}$ & $440 \mathrm{~cm}$ & - \\
\hline Parede frontal (O) & Interior & Arestas niveladas a $2,30 \mathrm{~m}$ & $220 \mathrm{~cm}$ & - \\
\hline Entrada (O) & & Arestas niveladas a $155 \mathrm{~cm}$ & $107 \mathrm{~cm}$ & - \\
\hline Boca da fornalha $(\mathrm{N})$ & & Arestas niveladas a $60 \mathrm{~cm}$ & $49 \mathrm{~cm}$ & $196 \mathrm{~cm}$ \\
\hline
\end{tabular}

Análise da Planta: Retangular com duas cabeceiras. estrutura

Estruturas Cobertura: Duas águas, em telha. exteriores Chaminé: Não tem.

Paredes: Parede N está parcialmente encostada a uma elevação de terreno. Sem elementos relevantes de análise.

Entrada: Orientada a O, de recorte retangular.

Porta: De metal.

Estruturas Cobertura: Em telha, suportado por vigas de madeira. interiores Apoios: Existem na parede E e N.

Paredes: Existe um canal de escoamento de água no canto inferior direito do banco da parede $\mathrm{E}$.

Saídas de Fumo: Não tem.

Janelas: Uma janela na parede S.

Chaminé: Acima da boca da fornalha, composta por três lajes de granito, e sustentada por dois cachorros.

Fornalha: Orientada a N, entrada de recorte quadrangular. Interior em cúpula revestida a tijolo refratário.

Porta da fornalha: Em metal.

\section{Notas de campo e informações adicionais:}

Não foi autorizada a divulgação do nome, idade e localização.

Informações relativas aos períodos de cozedura e aspetos culturais são iguais aos restantes fornos. 


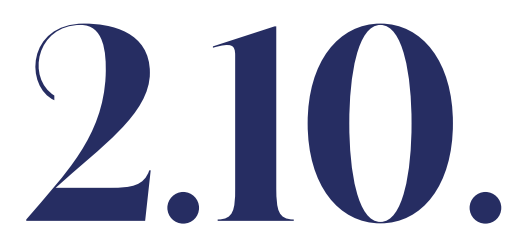

Ficha $n^{0} 33$ - Curveira

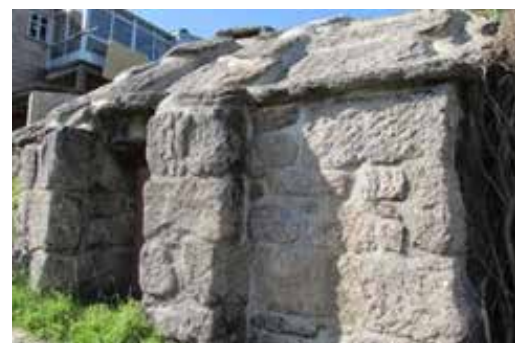

\section{Enquadramento administrativo e localização}

\begin{tabular}{ll}
\hline C.M.P. 1/25000 & $\mathrm{N}^{\circ} 004$ \\
\hline Coordenadas GPS & $42^{\circ} 0^{\prime}$ 44.8” N 8 9’ 2.2” W \\
\hline Coordenadas decimais & $42.012444,-8.150611$ \\
\hline Acessos & $\begin{array}{l}\text { Estrada nacional. Estrada secundária. } \\
\text { Estrada preferencialmente pedonal. }\end{array}$ \\
\hline Implantação & Terreno desnivelado \\
\hline Confrontações & Caminho público a S e E. Terreno \\
\hline Elevação & particular a N. Fontanário público a O. \\
\hline Orientação da entrada & 835mts \\
\hline Proteção existente & Não tem \\
\hline
\end{tabular}

Histórico

Referências documentais e bibliográficas: Livro de Atas de 2003-2011 - ata de 4/9/2004.

Registo predial ou urbano: Não tem.

Data de construção: Não há memória Período de atividade: Memória da última cozedura data de 2008.

Restauros: Último restauro em 2004. Proprietários: Não tem.

Gestores: A comunidade daquele lugar. Construtores: Não há memória. Situação atual: Inativo.

Características

Técnica construtiva: Pedra aparelhada Gerais com revestimentos e preenchimentos em cimento.

Materiais presentes: Granito, cimento, telha e madeira.

Capacidade da fornalha: 20 pães.

Produtos confecionados: Pão.

\section{Dimensões}

\begin{tabular}{lllll}
\hline Secções do forno & & Altura & Largura & Prof. \\
\hline & Exterior & Aresta à esquerda $-252 \mathrm{~cm}$ & $360 \mathrm{~cm}$ & - \\
& & & \\
& & Aresta à direita $-182 \mathrm{~cm}$ & & \\
& Cumieira - má visibilidade & & \\
\hline Parede lateral (E) & Interior & Aresta à esquerda $-237 \mathrm{~cm}$ & $342 \mathrm{~cm}$ & - \\
& & Aresta à direita $-233 \mathrm{~cm}$ & &
\end{tabular}




\begin{tabular}{lllll} 
& & Cumieira $-356 \mathrm{~cm}$ & & \\
& Exterior & Aresta à direita $-2,56 \mathrm{~m}$ & $754 \mathrm{~cm}$ & - \\
& & Aresta à esquerda $-115 \mathrm{~cm}$ & & \\
\hline Parede frontal $\mathbf{( S )}$ & Interior & Aresta à direita $-200 \mathrm{~cm}$ & $465 \mathrm{~cm}$ & - \\
& & Aresta à esquerda $-233 \mathrm{~cm}$ & & \\
\hline Entrada $(\mathbf{S})$ & Arestas niveladas a $178 \mathrm{~cm}$ & $113 \mathrm{~cm}$ & - \\
\hline Boca da fornalha $(\mathbf{O})$ & Arestas niveladas $55 \mathrm{~cm}$ & $47 \mathrm{~cm}$ & $185 \mathrm{~cm}$ \\
\hline
\end{tabular}

Análise da Planta: Retangular com cabeceira. estrutura

Estruturas Cobertura: Telhado de duas águas, em lajes de granito.

exteriores Chaminé: Chaminé em granito, ao centro da cobertura, encimada por uma laje de granito.

Paredes: Parede S com contrafortes. Parede N com contraforte (do arco interno ao centro), parcialmente encostada a uma elevação de terreno.

Entrada: Orientada a S, de recorte retangular, embutida nos contrafortes que sustentam os arcos.

Porta: Em metal.

Estruturas Cobertura: Cobertura sustentada por dois arcos de volta perfeita, interiores assentes em contrafortes visíveis no exterior, e duas estruturas triangulares compostas por esteios, diretamente acima da câmara da fornalha.

Apoios: Existem em redor do forno.

Paredes: Duas colunas, uma na parede N e outra na parede S.

Saidas de Fumo: Não tem.

Janelas: Uma na parede E.

Chaminé: Não tem.

Fornalha: Orientado a O, entrada de recorte quadrangular. Interior em cúpula revestida a tijolo refratário. Originalmente em pedra.

Porta da fornalha: Em metal.

\section{Notas de campo e informações adicionais:}

Informações prestadas no dia 8/7/2014, por Maria (68 anos), residente no lugar de Curveira: Após revestimento da fornalha a "briques" (tijolo refratário), deixou-se de cozer uma vez que a intenção de melhorar a cozedura não aconteceu. 


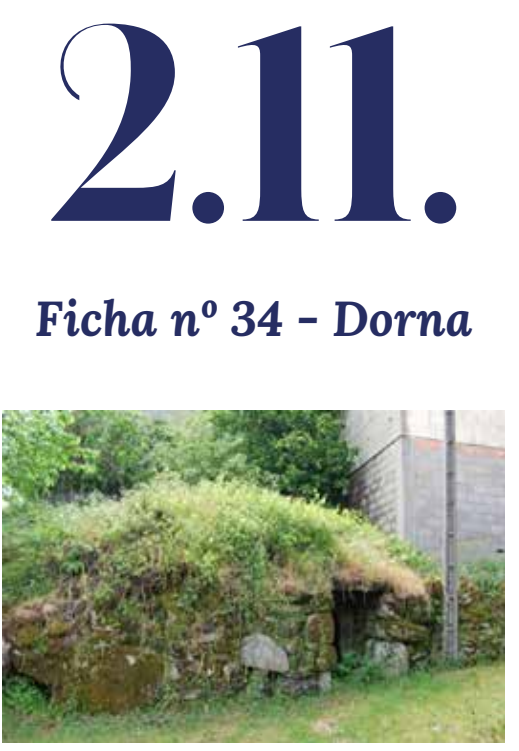

\section{Enquadramento administrativo e localização}

\begin{tabular}{ll}
\hline C.M.P. 1/25000 & $\mathrm{N}^{\circ} 009$ \\
\hline Coordenadas GPS & $41^{\circ} 59^{`}$ 32.3” N 8 10`9.8” W \\
\hline Coordenadas decimais & 41.992306, -8.169389 \\
\hline Acessos & $\begin{array}{l}\text { Estrada municipal. Estrada } \\
\text { secundária. Caminho pedonal. }\end{array}$ \\
\hline Implantação & Terreno nivelado \\
\hline Confrontações & $\begin{array}{l}\text { Caminho público a E. Terrenos e } \\
\text { imóveis particulares a N, S e O. }\end{array}$ \\
\hline Elevação & 822mts \\
\hline Orientação da entrada & E \\
\hline Proteção existente & Não tem \\
\hline
\end{tabular}

Histórico

Referências documentais e bibliográficas:

Não tem.

Registo predial ou urbano: Não tem.

Data de construção: Não há memória.

Período de atividade: A memória da última cozedura data de 1959.

Restauros: Não há memória de restauros.

Proprietários: Não tem.

Gestores: A comunidade daquele lugar.

Construtores: Não há memória.

Situação atual: Inativo.

Caracteristicas Técnica construtiva: Pedra aparelhada.

Gerais

Materiais presentes: Granito.

Capacidade da fornalha: 15 pães

Produtos confecionados: Pão.

\section{Dimensões}

\begin{tabular}{lllll}
\hline Secções do forno & & Altura & Largura & Prof. \\
\hline & Exterior & Obstruída & Obstruída & - \\
\hline Parede lateral $(\mathbf{N})$ & Interior & Aresta à direita $-105 \mathrm{~cm}$ & $2,88 \mathrm{~m}$ & - \\
& & $\begin{array}{l}\text { Aresta à esquerda }-81 \mathrm{~cm} \\
\text { Cumieira }-190 \mathrm{~cm}\end{array}$ & & \\
& & Arestas niveladas a $142 \mathrm{~cm}$ & $5,30 \mathrm{~m}$ & - \\
\hline Parede frontal $\mathbf{( E )}$ & Interior & Arestas niveladas a $128 \mathrm{~cm}$ & $2,72 \mathrm{~m}$ & - \\
\hline Entrada $(\mathbf{E})$ & & $138 \mathrm{~cm}$ & $91 \mathrm{~cm}$ & - \\
\hline Boca da fornalha $\mathbf{( S )}$ & & $51 \mathrm{~cm}$ & $57 \mathrm{~cm}$ & $170 \mathrm{~cm}$ \\
\hline
\end{tabular}


Análise da estrutura

Estruturas exteriores

Estruturas interiores
Planta: Retangular com cabeceira.

Cobertura: Duas águas, em granito.

Chaminé: Não tem ou está oculta na vegetação.

Paredes: Paredes S e O encostadas a uma elevação de terreno.

Entrada: Orientada a E, de recorte retangular. Ao lado direito, no chão, está um elemento arquitetónico em granito, escavado, retangular, de pequenas dimensões, talvez um contentor para água.

Porta: Sem porta.

Cobertura: Cobertura suportada por 2 arcos de volta perfeita assentes no chão.

Apoios: Um em à frente da fornalha.

Paredes: Parede O entra pela elevação de terreno. Restantes paredes sem elementos relevantes de análise.

Saídas de Fumo: Uma saída de fumo na parede N.

Janelas: Não tem.

Chaminé: Não tem.

Fornalha: Orientado a S, de recorte quadrangular. Interior em cúpula de granito.

Porta da fornalha: Não tem.

\section{Notas de campo e informações adicionais:}

Não se encontrou ninguém para obter informações adicionais sobre, por exemplo, o que justifica ter um pé tão baixo. 


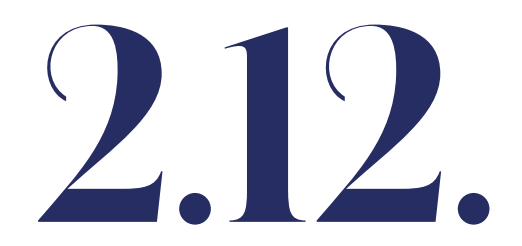

Ficha $n^{0} 35$ - Entalada

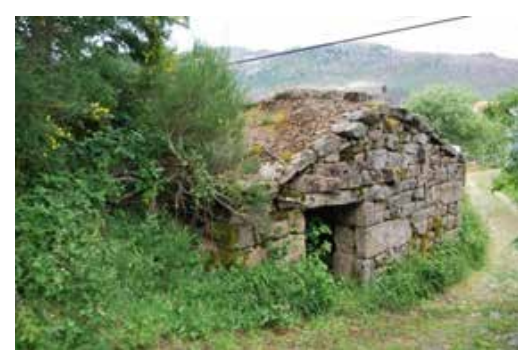

Histórico

Caracteristicas Gerais

\section{Enquadramento administrativo e localização}

\begin{tabular}{|c|c|}
\hline C.M.P. 1/25000 & $\mathrm{N}^{\circ} 009$ \\
\hline Coordenadas GPS & $41^{\circ} 59^{\prime} 19.5^{\prime \prime} \mathrm{N} 8^{\circ} 10^{\prime} 16.8^{\prime \prime}$ \\
\hline Coordenadas decimais & $41.988750,-8.171333$ \\
\hline \multirow{2}{*}{ Acessos } & Estrada municipal. \\
\hline & Estrada secundária. \\
\hline Implantação & Terreno nivelado \\
\hline Confrontações & $\begin{array}{l}\text { Caminho público a S. Imóveis e } \\
\text { terrenos particulares a N, O e E. }\end{array}$ \\
\hline Elevação & $837 \mathrm{mts}$ \\
\hline Orientação da entrada & $\mathrm{S}$ \\
\hline Proteção existente & Não tem \\
\hline
\end{tabular}

Referências documentais e bibliográficas: Não tem.

Registo predial ou urbano: Não tem.

Data de construção: Não há memória.

Periodo de atividade: Última cozedura data de há cerca de 1974.

Restauros: Restauro data de 1954.

Proprietários: Não tem.

Gestores: A comunidade daquele lugar.

Construtores: Não há memória.

Situação atual: Inativo.

Técnica construtiva: Pedra aparelhada com revestimentos e preenchimentos em cimento.

Materiais presentes: Granito e cimento. Capacidade da fornalha: 15 pães.

Produtos confecionados: Pão.

\section{Dimensões}

\begin{tabular}{lllll}
\hline Seções do forno & & Altura & Largura & Prof. \\
\hline & Exterior & Aresta à direita $-250 \mathrm{~cm}$ & $514 \mathrm{~cm}$ & - \\
& & Aresta à esquerda $-225 \mathrm{~cm}$ & & \\
\hline Parede lateral (E) & Interior & Aresta à direita $-210 \mathrm{~cm}$ & $315 \mathrm{~cm}$ & - \\
& & Aresta à esquerda $-200 \mathrm{~cm}$ & & \\
& Exterior & Aresta à esquerda $-149 \mathrm{~cm}$ & $670 \mathrm{~cm}$ &
\end{tabular}


Cumieira $-295 \mathrm{~cm}$

\begin{tabular}{lllll}
\hline Parede frontal (S) & Interior & $\begin{array}{l}\text { Arestas niveladas a } 208 \mathrm{~cm} \\
\text { Cumieira }-295 \mathrm{~cm}\end{array}$ & $527 \mathrm{~cm}$ & - \\
\hline Entrada $(\mathbf{S})$ & $150 \mathrm{~cm}$ & $106 \mathrm{~cm}$ & - \\
\hline Boca da fornalha $(\mathbf{N})$ & $52 \mathrm{~cm}$ & $45 \mathrm{~cm}$ & $170 \mathrm{~cm}$ \\
\hline
\end{tabular}

Análise da Planta: Retangular com cabeceira.

estrutura

Estruturas Cobertura: Telhado de duas águas revestido com cimento e exteriores pequenos seixos.

Chaminé: Não tem.

Paredes: Parede O encostada a uma elevação de terreno. Canal de escoamento de água por baixo do apoio na parede E.

Entrada: Orientada a S, de recorte retangular.

Porta: Sem porta. A porta anterior, de madeira, encontra-se dentro do forno, no chão, em estado de apodrecimento.

Estruturas Cobertura: Estrutura de suporte, triangular, composta por interiores esteios, apoiados em cachorros.

Apoios: Um à entrada da fornalha. Um na parede O e um na parede S.

Paredes: Meia coluna que sustenta a estrutura de sustentação na parede E. Na parede S existe um bloco de granito saliente, também visível do exterior.

Saídas de Fumo: Duas saídas de fumo na junção das duas águas. Uma saída de fumo na parede $\mathrm{O}$.

Janelas: Uma janela do lado E. Pequeno bloco em granito na parte inferior da janela.

Chaminé: Não tem.

Fornalha: Orientada a N, entrada de recorte quadrangular. Interior em cúpula de granito. Dois cachorros por cima da entrada do forno de cozer (serviriam de suporte a uma chaminé).

Porta da fornalha: Não tem.

\section{Notas de campo e informações adicionais:}

Informações prestadas no dia 2/10/2014, Duartina Fernandes (mais de 65 anos), residente no Teso e por Alzira Rodrigues, residente em Campelo:

Deixou-se de cozer neste forno por levar muito tempo a aquecer. 


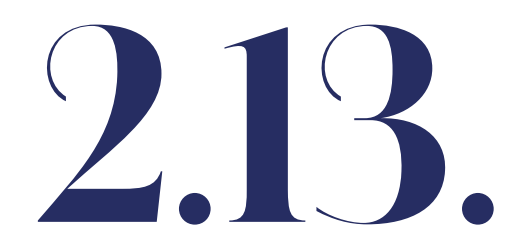

Ficha $n^{0} 36$ - Laceiras

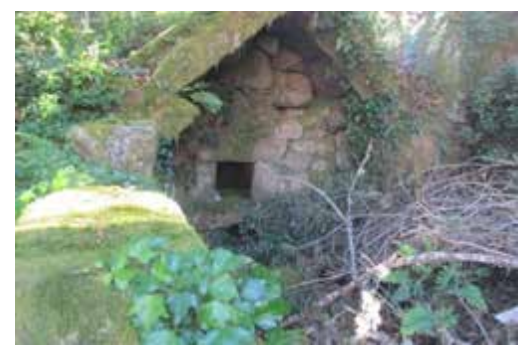

\section{Enquadramento administrativo e localização}

\begin{tabular}{ll}
\hline C.M.P. 1/25000 & $\mathrm{N}^{\circ} 004$ \\
\hline Coordenadas GPS & $42^{\circ} 1^{\prime} 1.9^{\prime \prime} \mathrm{N} 8^{\circ}$ 9 $^{\prime} 56.4^{\prime \prime} \mathrm{W}$ \\
\hline Coordenadas decimais & $42.017194,-8.165667$ \\
\hline Acessos & $\begin{array}{l}\text { Estrada municipal. Estrada } \\
\text { secundária. Caminho pedonal. }\end{array}$ \\
\hline Implantação & Terreno desnivelado. \\
\hline Confrontações & Caminho público a NE e SE. \\
\hline Elevação & Terrenos baldios a NO e SO. \\
\hline Orientação da entrada & N78mts \\
\hline Proteção existente & \\
\hline
\end{tabular}

Histórico

Referências documentais e bibliográficas:

Não tem.

Registo predial ou urbano: Não tem.

Data de construção: Não há memória.

Periodo de atividade: Memória da última cozedura data de 1954.

Restauros: Não há memória.

Proprietários: Não tem.

Gestores: A comunidade daquele lugar.

Construtores: Não há memória.

Situação atual: Inativo.

Características Técnica construtiva: Pedra aparelhada.

Gerais

Materiais presentes: Granito.

Capacidade da fornalha: 13 pães.

Produtos confecionados: Pão.

\section{Dimensões}

\begin{tabular}{|c|c|c|c|c|}
\hline \multirow[t]{4}{*}{ Secções do forno } & & Altura & Largura & Prof. \\
\hline & Exterior & $\begin{array}{l}\text { Aresta à direita (na parede } \\
\text { da fornalha) }-250 \mathrm{~cm}\end{array}$ & $\begin{array}{l}740 \mathrm{~cm} \text { (parede } \\
\text { completa) }\end{array}$ & - \\
\hline & & $\begin{array}{l}\text { Aresta à esquerda (onde } \\
\text { termina, na cabeceira) }-180 \mathrm{~cm}\end{array}$ & & \\
\hline & & (restante parede em ruína) & & \\
\hline \multirow[t]{2}{*}{ Parede lateral (SE) } & Interior & $\begin{array}{l}\text { Arestas niveladas a } 170 \mathrm{~cm} \text { (na } \\
\text { parede da fornalha) }\end{array}$ & $490 \mathrm{~cm}$ & - \\
\hline & Exterior & Ruína & $295 \mathrm{~cm}$ & - \\
\hline
\end{tabular}




\begin{tabular}{lllll} 
Parede frontal (NE) & Interior & $\begin{array}{l}\text { (na parede da fornalha) } \\
\text { Arestas niveladas a } 160 \mathrm{~cm} \\
\text { Cumieira }-250 \mathrm{~cm}\end{array}$ & $275 \mathrm{~cm}$ & - \\
& Arruinada & $116 \mathrm{~cm}$ & - \\
\hline Entrada (NE) & Arestas nivelas a $55 \mathrm{~cm}$ & $47 \mathrm{~cm}$ & $172 \mathrm{~cm}$ \\
\hline Boca da fornalha (SO) & &
\end{tabular}

Análise da Planta: Retangular com cabeceira.

estrutura

Estruturas Cobertura: Duas Águas, em granito.

exteriores Chaminé: Não tem ou não está visível.

Paredes: Parede SO encostada a uma elevação de terreno.

Restantes sem elementos relevantes de análise.

Entrada: Orientada a NE.

Porta: Não tem.

Estruturas Cobertura: (Apenas se pode fazer uma avaliação de uma parte, interiores a que corresponde à parcela da fornalha) - Em lajes de granito suportadas por uma estrutura triangular, composta por dois esteios de granito, que assenta do lado esquerdo numa outra laje da parede SE, e do lado direito num bloco de granito embutido na elevação de terreno.

Apoios: Parede SE sem apoios. Parede NO encontra-se obstruída com matéria orgânica, mas tudo indica que exista uma bancada corrida a todo o comprimento. Balcão corrido em frente ao forno de cozer e na parede NO, ao lado da fornalha, existe um bloco retangular granítico de pequenas dimensões, que serviria possivelmente de apoio.

Paredes: Na parede SE, ao lado do forno de cozer, existe uma reentrância que poderá ter sido uma janela.

Saídas de Fumo: Não existem.

Janelas: Não existem.

Chaminé: Diretamente acima do forno estão dois cachorros que serviram para suportar um dispositivo de saída de fumo.

Fornalha: Orientada a SO, entrada de recorte quadrangular. Interior em cúpula, de granito.

Porta da fornalha: Não tem.

\section{Notas de campo e informações adicionais:}

Informações prestadas no dia 2/10/2014, por Palmira Fernandes (88 anos), residente no Lugar da Vila:

Afirma que a sua família dispunha de um forno privado onde coziam os habitantes das Laceiras pelo motivo de o comunitário deixar o pão cru. 


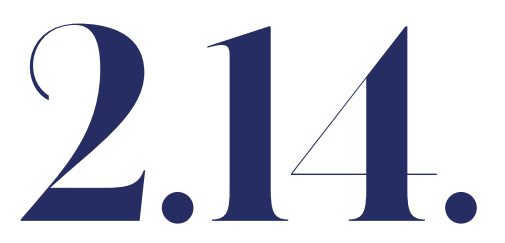

Ficha $n^{0} 37$ - Mareco

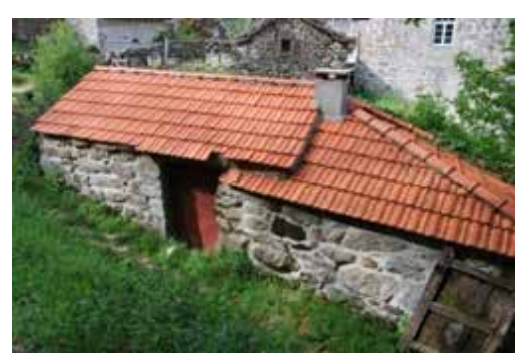

Histórico

\section{Enquadramento administrativo e localização}

\begin{tabular}{|c|c|}
\hline C.M.P. $1 / 25000$ & $\mathrm{~N}^{\circ} 009$ \\
\hline Coordenadas GPS & $41^{\circ} 58^{`} 59.4^{\prime \prime} \mathrm{N} 8^{\circ} 9^{`} 56.9^{\prime \prime} \mathrm{W}$ \\
\hline Coordenadas decimais & 41.983167, -8.165806 \\
\hline Acessos & $\begin{array}{l}\text { Estrada municipal. Estrada } \\
\text { secundária. Caminho pedonal. }\end{array}$ \\
\hline Implantação & Terreno desnivelado \\
\hline Confrontações & $\begin{array}{l}\text { Caminho público a SO, SE e NO. } \\
\text { Corga de água a NE. }\end{array}$ \\
\hline Elevação & $741 \mathrm{mts}$ \\
\hline Orientação da entrada & SO \\
\hline Proteção existente & \\
\hline
\end{tabular}

Referências documentais e bibliográficas:

Livro de Atas de 2003-2011 - ata de 1/4/2006.

Registo predial ou urbano: Não tem.

Data de construção: Não há memória.

Período de atividade: Memória da última cozedura data de 2011.

Restauros: Último restauro em 2006.

Proprietários: Não tem.

Gestores: A comunidade daquele lugar.

Construtores: Não há memória.

Situação atual: Ativo.

Características Técnica construtiva: Pedra aparelhada

Gerais cimento.

Materiais presentes: Granito, cimento, telha e madeira.

Capacidade da fornalha: 14 pães.

Produtos confecionados: Pão.

\section{Dimensões}

\begin{tabular}{lllll}
\hline Secções do forno & Altura & Largura & Prof. \\
\hline & Exterior & Aresta à direita $-111 \mathrm{~cm}$ & $285 \mathrm{~cm}$ & - \\
& & Aresta à esquerda - obstruída & & \\
& & Cumieira $-200 \mathrm{~cm}$ & \\
\hline Parede lateral (NO) & Interior & Aresta à direita $-228 \mathrm{~cm}$ & $246 \mathrm{~cm}$ & - \\
& & Aresta à esquerda $-235 \mathrm{~cm}$ & &
\end{tabular}




\begin{tabular}{lllll} 
& & Cumieira $-330 \mathrm{~cm}$ & & \\
& Exterior & $\begin{array}{l}\text { Aresta à direita }-185 \mathrm{~cm} \\
\text { Aresta à esquerda- } 110 \mathrm{~cm}\end{array}$ & $850 \mathrm{~cm}$ & - \\
& & & \\
\hline Parede frontal $\mathbf{( S O )}$ & Interior & Aresta à direita $-235 \mathrm{~cm}$ & $580 \mathrm{~cm}$ & - \\
& & Aresta à esquerda $-198 \mathrm{~cm}$ & & \\
\hline Entrada $\mathbf{( S O )}$ & & Arestas niveladas a $160 \mathrm{~cm}$ & $102 \mathrm{~cm}$ & - \\
\hline Boca da fornalha $\mathbf{( S )}$ & Arestas niveladas a $53 \mathrm{~cm}$ & $55 \mathrm{~cm}$ & $170 \mathrm{~cm}$ \\
\hline
\end{tabular}

Análise da estrutura

Estruturas exteriores

Estruturas interiores
Planta: Retangular com cabeceira.

Cobertura: Duas águas. A parte virada a nascente seja de três águas. Cobertura restaurada recentemente em cimento e telha. Chaminé: Chaminé em tijolo e cimento.

Paredes: Sem elementos relevantes de análise.

Entrada: Orientada a SO, de recorte retangular.

Porta: Porta em metal, (a porta de madeira, antiga, encontra-se encostada na parede frontal do forno, no exterior).

Cobertura: Em telha, suportado por vigas e traves de madeira. Existe uma arquitrave correspondente a uma cobertura anterior. Esta estrutura é composta por uma laje de granito ligeiramente arqueada, apoiada em dois "capitéis" largos, que coroam as colunas de granito compostas por blocos de granitos sobrepostos. Uma coluna encontra-se adossada à parede SO e outra à parede NE. Esta estrutura está atualmente a suportar as traves de madeira do telhado, e conserva no topo algumas lajes da estrutura de sustentação anterior.

Apoios: Um na parede NE um em frente à fornalha, unida ao banco da parede NE, terminando em canto e prolongando-se ligeiramente pela parede SO.

Paredes: Tapadas com lenha.

Saídas de Fumo: Não tem.

Janelas: Uma na parede NO.

Chaminé: Em cimento, de três faces, terminando com um rebordo geométrico.

Fornalha: Orientada a S, entrada de recorte quadrangular. Interior em cúpula revestida a tijolorefratário. Uma das pedras da parede da fornalha, ao lado direito desta, contém a seguinte inscrição: "1932".

Porta da fornalha: Em metal. Entrada de recorte retangular. 
Notas de campo e informações adicionais:

Informações prestadas no dia 12/11/2014, por Leonor da Conceição Domingues, residente no Lugar da Vila:

Está encarregue de cuidar do forno. 


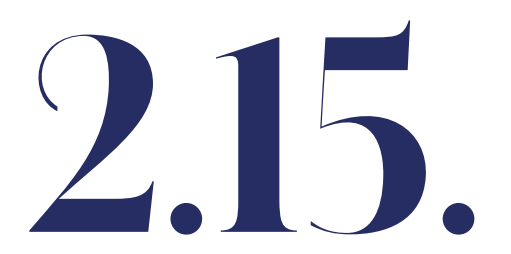

Ficha $n^{0} 38$ - Podre

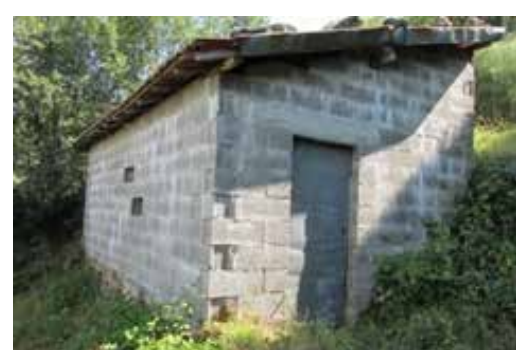

\section{Enquadramento administrativo e localização}

\begin{tabular}{ll}
\hline C.M.P. 1/25000 & $\mathrm{N}^{\circ} 009$ \\
\hline Coordenadas GPS & $42^{\circ} 0^{\prime} 10^{\prime \prime} \mathrm{N} \mathrm{8}$ 8 10` 8.9” W \\
\hline Coordenadas decimais & $42.002778,-8.169139$ \\
\hline Acessos & $\begin{array}{l}\text { Estrada municipal. Estrada } \\
\text { secundária. Caminho pedonal. }\end{array}$ \\
\hline Implantação & Terreno desnivelado \\
\hline Confrontações & $\begin{array}{l}\text { Caminho público e corga de } \\
\text { água a N. Fontanário público a E. } \\
\text { Terrenos particulares a S e O. }\end{array}$ \\
\hline Elevação & 780 mts. \\
\hline Orientação da entrada & $\mathrm{N}$ \\
\hline Proteção existente & Não tem \\
\hline
\end{tabular}

Histórico

Referências documentais e bibliográficas:

Não tem.

Registo predial ou urbano: Não tem.

Data de construção: Não há memória.

Periodo de atividade: Regularmente.

Restauros: Restauro em 1987.

Proprietários: Não tem.

Gestores: A comunidade daquele lugar.

Construtores: Não há memória.

Situação atual: Ativo.

Caracteristicas Técnica construtiva: Blocos de cimento Gerais aparelhados assentes em blocos de granito. Materiais presentes: Granito, cimento, telha e madeira.

Capacidade da fornalha: 9 pães.

Produtos confecionados: Pão.

\section{Dimensões}

\begin{tabular}{lllll}
\hline Secções do forno & & Altura & Largura & Prof. \\
\hline & Exterior & Arestas niveladas a $210 \mathrm{~cm}$ & $558 \mathrm{~cm}$ & - \\
\hline Parede lateral (E) & Interior & Aresta à direita $-232 \mathrm{~cm}$ & $357 \mathrm{~cm}$ & - \\
& & Aresta à esquerda $-240 \mathrm{~cm}$ & & \\
& \multirow{2}{*}{ Exterior } & Aresta à direita $-300 \mathrm{~cm}$ & $361 \mathrm{~cm}$ & - \\
& & & \\
& & Aresta à esquerda $-210 \mathrm{~cm}$ & & \\
\hline
\end{tabular}




\begin{tabular}{lllll} 
Parede frontal $(\mathbf{N})$ & Interior & $\begin{array}{l}\text { Aresta à direita }-240 \mathrm{~cm} \\
\text { Aresta à esquerda }-345 \mathrm{~cm}\end{array}$ & $300 \mathrm{~cm}$ & - \\
\hline Entrada $(\mathbf{N})$ & Arestas niveladas a $190 \mathrm{~cm}$ & $85 \mathrm{~cm}$ & - \\
\hline Boca da fornalha $(\mathbf{S})$ & Arestas niveladas a $50 \mathrm{~cm}$ & $48 \mathrm{~cm}$ & $160 \mathrm{~cm}$ \\
\hline
\end{tabular}

Análise da Planta: Retangular.
estrutura

Estruturas Cobertura: Uma água, em cimento.

exteriores Chaminé: Em cimento.

Paredes: Sem elementos relevantes de análise.

Entrada: Orientada a N, de recorte retangular.

Porta: Em madeira revestida com chapa de metal.

Estruturas Cobertura: Em telha suportado por vigas e traves.

interiores Apoios: Nas paredes E e O. Um em frente ao forno de cozer.

Paredes: Lisas, sem elementos relevantes, em blocos de cimento.

Saidas de Fumo: Não tem.

Janelas: Duas na parede E.

Chaminé: Acima do forno de cozer, suportada por dois cachorros em granito, 3 lajes na horizontal (3 faces), encimada por blocos de cimento que se prolongam de forma ascendente.

Fornalha: Orientada a S, recorte quadrangular. Interior em cúpula, revestida a tijolo refratário.

Porta da fornalha: Em metal.

\section{Notas de campo e informações adicionais:}

Informações prestadas no dia 12/11/2014, por Filipe Domingues, residente no Rodeiro: Este forno foi demolido e as pedras utilizadas para calcetar os caminhos. Anterior todo em pedra. Albertino Conde, também residente no Rodeiro, confirmou esta informação. 


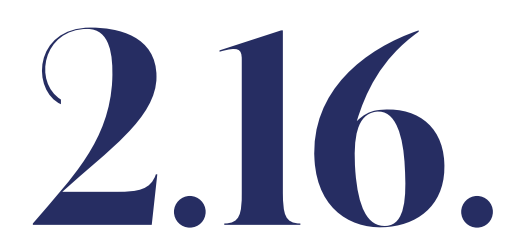

Ficha $n^{0} 39$ - Pontes

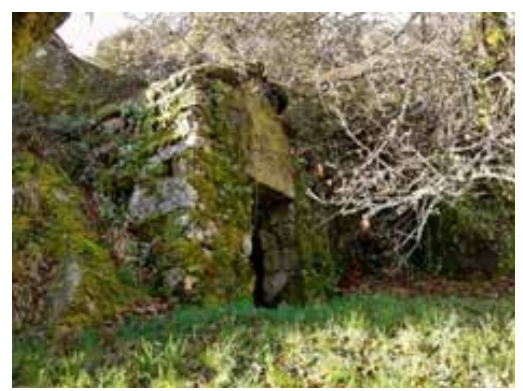

\section{Enquadramento administrativo e localização}

\begin{tabular}{|c|c|}
\hline C.M.P. 1/25000 & $\mathrm{N}^{\circ} 009$ \\
\hline Coordenadas GPS & $41^{\circ} 59^{\prime} 18.2^{\prime \prime} \mathrm{N} 8^{\circ} 9^{`} 48.3^{\prime \prime} \mathrm{W}$ \\
\hline Coordenadas decimais & $41.988389,-8.163417$ \\
\hline Acessos & $\begin{array}{l}\text { Estrada de ligação entre a M1160 } \\
\text { e a EN202-3. }\end{array}$ \\
\hline Implantação & $\begin{array}{l}\text { Em terreno desnivelado, } \\
\text { integrado num afloramento rochoso. }\end{array}$ \\
\hline Confrontações & Terreno particular a O, E, N e S. \\
\hline Elevação & $723 \mathrm{mts}$. \\
\hline Orientação da entrada & $\mathrm{N}$ \\
\hline Proteção existente & Não tem \\
\hline
\end{tabular}

Referências documentais e bibliográficas: Não tem.

Registo predial ou urbano: Não tem.

Data de construção: Não há memória.

Período de atividade: Memória da última cozedura data de 1974.

Restauros: Não há memória de restauros.

Proprietários: Não tem.

Gestores: A comunidade daquele lugar.

Construtores: Não há memória.

Situação atual: Inativo.

Características Técnica construtiva: Pedra aparelhada.

Gerais
Materiais presentes: Granito.

Capacidade da fornalha: 13 pães.

Produtos confecionados: Pão.

\section{Dimensões}

\begin{tabular}{lllll}
\hline Secções do forno & & Altura & Largura & Prof. \\
\hline & Exterior & Impossível medir & $\begin{array}{l}\text { Impossível } \\
\text { medir }\end{array}$ & - \\
\hline Parede lateral (O) & Interior & Aresta à esquerda $-154 \mathrm{~cm}$ & $261 \mathrm{~cm}$ & - \\
& & Aresta à direita $-292 \mathrm{~cm}$ & & \\
& Exterior & Aresta à direita $-174 \mathrm{~cm}$ & $480 \mathrm{~cm}$ & - \\
& & Aresta à esquerda $-268 \mathrm{~cm}$ & & \\
& & Cumieira - 348cm & \\
\hline
\end{tabular}




\begin{tabular}{lllll} 
Parede frontal $\mathbf{( N )}$ & Interior & Aresta à direita $-189 \mathrm{~cm}$ & $340 \mathrm{~cm}$ & - \\
& $\begin{array}{l}\text { Aresta à esquerda }-280 \mathrm{~cm} \\
\text { Cumieira }-345 \mathrm{~cm}\end{array}$ & & \\
& Arestas niveladas a $189 \mathrm{~cm}$ & $165 \mathrm{~cm}$ & - \\
\hline Entrada $(\mathbf{N})$ & Arestas niveladas a $56 \mathrm{~cm}$ & $45 \mathrm{~cm}$ & $186 \mathrm{~cm}$ \\
\hline Boca da fornalha $\mathbf{( S )}$ & &
\end{tabular}

Análise da Planta: (visível no interior) Retangular com cabeceira. estrutura

Estruturas Cobertura: Duas águas, composto por lajes de pedra, e dois exteriores penedos.

Chaminé: Não tem.

Paredes: Parede E e O são aproveitamentos de dois penedos, com remates de pequenos blocos de granito.

Entrada: Entrada orientada a N, retangular.

Porta: Não tem porta.

Estruturas Cobertura: A cobertura é o aproveitamento do vão de dois interiores grandes penedos (que servem de cobertura e de paredes laterais).

Apoios: Um na parede O. Um em frente ao forno de cozer. Paredes: Penedos visíveis no interior, sem elementos de destaque.

Saídas de Fumo: Uma no lado O, outro lado E.

Janelas: Não tem.

Chaminé: Não tem.

Fornalha: Orientado a S, entrada de recorte quadrangular. Interior em cúpula de granito. Cruz em baixo relevo numa pedra que integra a estrutura do forno de cozer.

Porta da fornalha: Porta em granito.

\section{Notas de campo e informações adicionais:}

Informações prestadas no dia 17 de novembro de 2014, por Angelina, sacristã da Igreja paroquial, residente no Lugar da Vila:

Nunca teve porta. 


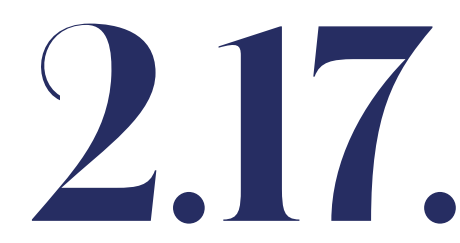

Ficha $n^{0} 40$ -

Ramisqueira

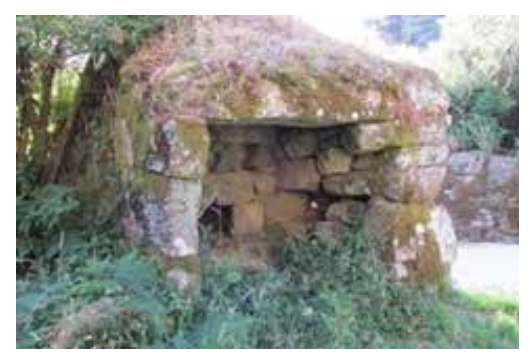

Histórico

Caracteristicas Gerais

\section{Enquadramento administrativo e localização}

\begin{tabular}{ll}
\hline C.M.P. 1/25000 & $\mathrm{N}^{\circ} 004$ \\
\hline Coordenadas GPS & $42^{\circ} 0^{\prime} 46.7^{\prime \prime} \mathrm{N} \mathrm{8}$ 8 $^{\prime} 10^{\prime}$ 1” W \\
\hline Coordenadas decimais & $42.012972,-8.166944$ \\
\hline Acessos & Estrada municipal. \\
& Estrada secundária. \\
\hline Implantação & Terreno nivelado \\
\hline Confrontações & Terreno privado a NE, NO, SE e SO. \\
\hline Elevação & 789mts. \\
\hline Orientação da entrada & NE \\
\hline Proteção existente & Não tem \\
\hline
\end{tabular}

Referências documentais e bibliográficas:

Possível referência no Cartório Notarial de Castro Laboreiro (1777-1855), livro de 18231837, $2^{\circ}$ ofício, folha 114 (verso).

Registo predial ou urbano: Não tem.

Data de construção: Não há memória.

Periodo de atividade: Memória da última cozedura data de 1993.

Restauros: Não há memória. Está inscrito num projeto para reabilitação.

Proprietários: Esperança Afonso, Eduardo Afonso e Laurinda Afonso.

Gestores: Esperança Afonso, Eduardo Afonso e Laurinda Afonso - na sua herança desde 1921.

Construtores: Não há memória. Pertencia a uma família anterior.

Situação atual: Inativo.

Técnica construtiva: Pedra aparelhada.

Materiais presentes: Granito.

Capacidade da fornalha: 10 pães.

Produtos confecionados: Pão.

\section{Dimensões}

\begin{tabular}{lllll}
\hline Secções do forno & & Altura & Largura & Prof. \\
\hline & Exterior & Arestas niveladas a $210 \mathrm{~cm}$ & $320 \mathrm{~cm}$ & - \\
\hline
\end{tabular}




\begin{tabular}{lllll} 
Parede lateral (NO) & $\begin{array}{l}\text { Interior } \\
\text { Exterior }\end{array}$ & Arestas niveladas a $168 \mathrm{~cm}$ & $150 \mathrm{~cm}$ & - \\
& Não existe & $265 \mathrm{~cm}$ & - \\
\hline Parede frontal (NE) & Interior & Não existe & - & - \\
\hline Entrada (NE) & & Arestas niveladas a $210 \mathrm{~cm}$ & $265 \mathrm{~cm}$ & - \\
\hline Boca da fornalha (SO) & Arestas niveladas a $45 \mathrm{~cm}$ & $44 \mathrm{~cm}$ & $150 \mathrm{~cm}$ \\
\hline
\end{tabular}

Análise da Planta: Quadrangular com cabeceira.

estrutura

Estruturas Cobertura: Duas águas, em lajes de granito.

exteriores Chaminé: Oculta ou inexistente.

Paredes: Sem elementos relevantes de análise.

Entrada: Orientada a NE, aberta, sem parede frontal.

Porta: Sem porta.

Estruturas Cobertura: Rasa. Composta por lajes de granito na horizontal.

interiores Apoios: Uma em frente à fornalha.

Paredes: Parede NO tem um nicho quadrangular que poderá ter sido uma janela.

Saídas de Fumo: Uma na parede NO, no canto superior esquerdo. Janelas: Não tem.

Chaminé: Não tem.

Fornalha: Orientada a SO, de entrada quadrangular.

Porta da fornalha: Não tem.

\section{Notas de campo e informações adicionais:}

Informações prestadas no dia 13/11/2014, por Eduardo Afonso, ex-residente da Ramisqueira, herdeiro deste forno:

Para aquecer carecia de 6 feixes de lenha, e de 3 feixes de lenha de uma cozedura para a outra. Nunca teve porta. Esta é a estrutura original. 


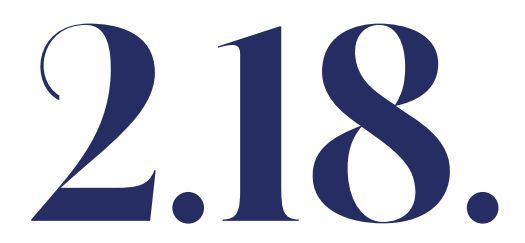

Ficha $n^{0} 41$ - Varziela

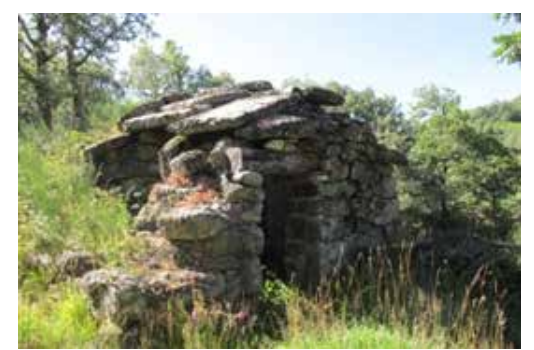

Histórico

\section{Características Gerais}

\section{Enquadramento administrativo e localização}

\begin{tabular}{ll}
\hline C.M.P. 1/25000 & $\mathrm{N}^{\circ} 004$ \\
\hline Coordenadas GPS & $42^{\circ} 1^{\prime} 33.4^{\prime \prime}$ N 8 8' 44.9" W \\
\hline Coordenadas decimais & $42.025944,-8.145806$ \\
\hline Acessos & $\begin{array}{l}\text { Estrada nacional. Estrada } \\
\text { secundária. Caminho pedonal. }\end{array}$ \\
\hline Implantação & Terreno desnivelado \\
\hline Confrontações & $\begin{array}{l}\text { Caminho público a E e S. } \\
\text { Terreno particular a N e O. }\end{array}$ \\
\hline Elevação & 954 mts. \\
\hline Orientação da entrada & E \\
\hline Proteção existente & Não tem \\
\hline
\end{tabular}

Referências documentais e bibliográficas:

Não tem.

Registo predial ou urbano: Não tem.

Data de construção: Não há memória.

Período de atividade: Última cozedura data de 1958.

Restauros: Não há memória.

Proprietários: Não tem.

Gestores: A comunidade daquele lugar.

Construtores: Não há memória.

Situação atual: Inativo.

Técnica construtiva: Pedra aparelhada com revestimentos e preenchimentos em argamassa.

Materiais presentes: Granito, madeira, um tipo de argamassa não identificado.

Capacidade da fornalha: 15 pães.

Produtos confecionados: Pão.

\section{Dimensões}

\begin{tabular}{lllll}
\hline Secções do forno & & Altura & Largura & Prof. \\
\hline & Exterior & Arestas niveladas a $190 \mathrm{~cm}$ & $600 \mathrm{~cm}$ & - \\
\hline Parede lateral (S) & Interior & Arestas niveladas a $210 \mathrm{~cm}$ & $395 \mathrm{~cm}$ & - \\
& Exterior & Arestas niveladas a $210 \mathrm{~cm}$ & $470 \mathrm{~cm}$ & - \\
& & Cumieira $-294 \mathrm{~cm}$ & \\
\hline Parede frontal (E) & \multirow{2}{*}{ Interior } & Aresta à direita $-180 \mathrm{~cm}$ & $233 \mathrm{~cm}$ & - \\
& & Aresta à esquerda $-172 \mathrm{~cm}$ & &
\end{tabular}


Cumieira $-287 \mathrm{~cm}$

\begin{tabular}{llll}
\hline Entrada $(\mathbf{E})$ & Arestas niveladas a $190 \mathrm{~cm}$ & $94 \mathrm{~cm}$ & - \\
\hline Boca da fornalha $(\mathbf{O})$ & Arestas niveladas $53 \mathrm{~cm}$ & $48 \mathrm{~cm}$ & $190 \mathrm{~cm}$ \\
\hline
\end{tabular}

Análise da Planta: Retangular com cabeceira.

estrutura

Estruturas Cobertura: Duas águas. Em lajes de granito.

exteriores Chaminé: Não tem - a saída de fumo processa-se por um orifício na cobertura.

Paredes: Parede S está parcialmente em ruína. Base larga em granito ao lado da parede S. Parede O assenta numa elevação de terreno.

Entrada: Orientada a E, de recorte retangular, encimada por uma trave de madeira.

Porta: Sem porta.

Estruturas

Cobertura: Suportado por um monólito arqueado, assente numa interiores coluna rudimentar do lado direito, e do lado esquerdo na parede. Apoios: Em frente ao forno de cozer, existem dois apoios que possivelmente sustentariam um balcão. Existe um pequeno banco (bloco granítico) na parede N, que faz parte da base da coluna.

Paredes: Parede $\mathrm{N}$ apresenta uma reentrância que poderá ter sido uma janela e tem também uma saída de fumo tosca. $\mathrm{Na}$ parede S (ao lado da entrada) existe uma outra reentrância quadrangular de maior dimensão que a da parede Norte que não indica uma função explícita. Na parede E está uma outra reentrância quadrangular de pequenas dimensões, que poderá ter sido parte de um sistema de fecho do forno, ou uma pedra aproveitada de outra construção.

Saídas de Fumo: Uma na parede N.

Janelas: Não tem.

Chaminé: Chaminé rudimentar composta por um canal largo que termina numa saída de fumo, de pequena dimensão.

Fornalha: Orientada a $\mathrm{O}$, de recorte quadrangular. Interior em cúpula de granito.

Porta da fornalha: Não tem.

\section{Notas de campo:}

Informações prestadas no dia 2/10/2014, por Virgínia (92 anos), residente na Vila:

Não há recordação de alguma vez ter sido restaurado. 


\section{Os dois fornos demolidos} nas "invernciras", durante o sćculo XX
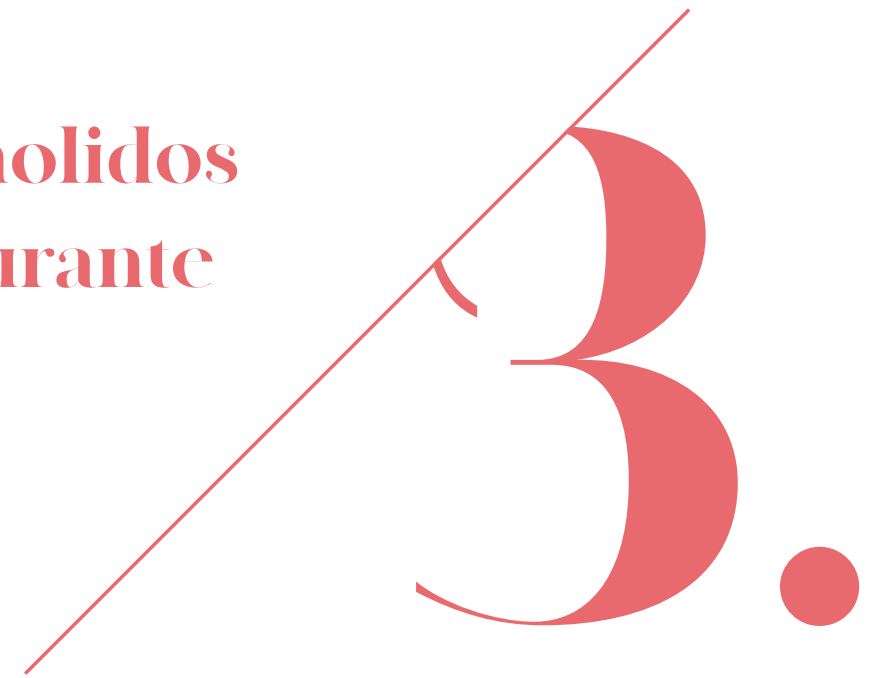

Sobre estes dois fornos, que incluímos na contagem total dos 53 anunciados no título do artigo, e para os quais foi aberta uma ficha de inventário, apenas foi possível recolher informações através de conversas informais com a população. Os conteúdos ficaram integrados na secção "notas de campo".

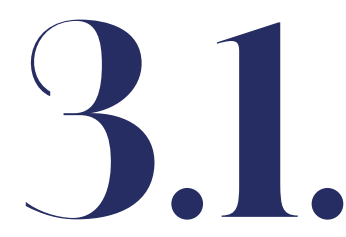

\section{Ficha $n^{0} 42$ - Assureira}

\section{Notas de campo e informações adicionais:}

Referência no livro de Atas de 1977-1987 - Ata de 6/11/1983 - p.62 - “(...) onde foram gastos grande quantidade de tubaria em cimento e bastantes metros de cimento armado que em muito foi beneficiar este dito lugar (...)" - terá sido nesta altura que o forno comunitário foi demolido. Informações prestadas no dia 11/9/2014, por Manuel Rodrigues, residente na Vila, e Armandino Esteves, residente em Adofreire:

Os participantes neste desmantelamento foram o Sr. Armandino Esteves, o Sr. Manuel Esteves e o Sr. Manuel Domingues. Além de alargar a estrada o objetivo era reutilizar as pedras para se fazer um tanque de água comunitário para que os habitantes de Assureira não tivessem de lavar a roupa ao rio. Plano que não se concretizou. As pedras do forno compõem hoje em dia os muros que se fizeram no prolongamento da estrada. Relativamente à localização características do forno: estava localizado à entrada do Lugar. Cobertura de duas águas. Estrutura em granito. Não há memória da sua origem. Capacidade para 12 ou 13 broas. Era costume de em dias de casamento ou festa se fazer "o assado" que consistia em cabrito ou anho. 


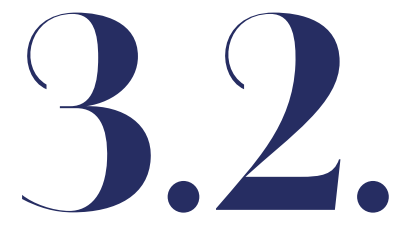

\section{Ficha $n^{0} 43$ - Ramisqueira}

Notas de campo e informações adicionais:

Informações prestadas no dia 14/10/2014, por Marcelo Afonso:

O Forno Comunitário original foi demolido para se fazer um alargamento da estrada, para que "os carros pudessem fazer manobras". Usaram-se as suas pedras para construir um muro. A configuração deste forno era muito semelhante ao "privado" que se encontra na parte de cima. Era difícil de aquecer e, por isso, permitiam que se cozesse no privado. Era todo em pedra, incluindo a cobertura. Tinha capacidade para 10 pães. A Memória da última cozedura data da década de 60 ou da década de 70. Nunca foi restaurado. Não tinha apoios. Não tinha chaminés, nem janelas nem orifícios de qualquer tipo - nem faria muito sentido que as tivesse visto ser uma câmara aberta. Estava orientado a Norte. A fornalha tinha a porta em pedra. Estava em terreno desnivelado. 


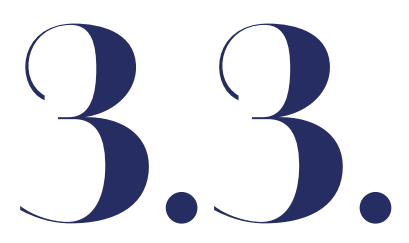

\section{Ficha $n^{0} 44$ - Bago de Baixo}

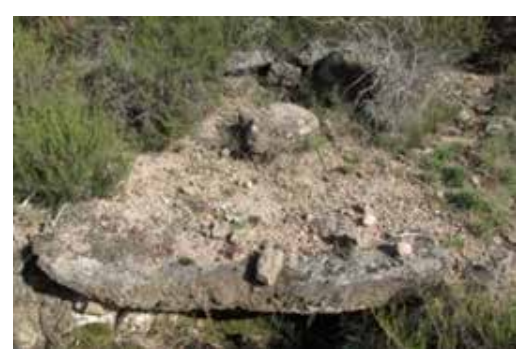

Notas de campo e informações adicionais:

Referido por Maria Rúbia e o Arlindo Pires, habitantes da Seara e do Bago de Baixo. Foi também sugerido por Leonor Esteves, habitante do Lugar da Ameijoeira e do Bago de Baixo. Foi na companhia de Leonor Esteves que se procurou e encontrou o que resta deste forno. Indicou que os seus familiares mais velhos se recordam deste ser um antigo forno comunitário, caído em desuso ao longo dos anos, não havendo qualquer memória da sua forma ou atividade. Talvez tenha sido desmantelado. Após análise creio tratar-se de uma ruína de um forno. Em redor da laje existe uma planta retangular com cabeceira ovalada, onde ainda são visíveis algumas pedras no chão. Existe um vão largo por baixo desta laje, indicando talvez o lugar de uma "borralheira". A parte superior da laje apresenta ter extensão suficiente para sustentar uma "fornalha", em cúpula. Existe ainda um extenso aglomerado de ruínas na margem do rio, a alguns metros deste forno. Este aglomerado de ruínas poderá ter sido um lugar, ao qual corresponderia este forno.

No campo da especulação, partindo do princípio que existe ligação com as ruínas na margem do rio, este forno estaria bem situado, encontrando-se num local arejado, pouco húmido e sombrio (situações que noutros casos dificultam o processo de aquecimento), tem fácil serventia a água corrente (conforme acontece com a maioria dos fornos) e encontra-se deslocado das tais ruínas, conforme se verifica com os restantes fornos comunitários, que por uma questão de segurança das casas, uma vez que o forno libertavam faúlhas durante o aquecimento e os telhados eram em colmo, eram normalmente construídos à margem do lugar.

Todavia é um caso que fica por apurar. 
Fontes manuscritas e impressas

AHDVC $-1^{\circ}$ ofício (4 livros e 2 cadernos, 1777-1823), e $2^{\circ}$ ofício (2 livros e 2 cadernos, 1823-1855). Cartório Notarial do Concelho de Castro Laboreiro (1777-1855).

AHMM - CÂMARA MUNICIPAL DE CASTRO LABOREIRO (18421849) - Livro de Atas da Câmara Municipal de Castro Laboreiro (31.08.1842 a 21.04.1849). Cota. MMLG.1.1.5.74

SJFCLLM - JUNTA DE FREGUESIA DE CASTRO LABOREIRO (1959-2013) - Livros de Atas da Junta de Freguesia de Castro Laboreiro (06.02.1977 a 26.09.2013). S/cota.

SJFCLLM - JUNTA DE FREGUESIA DE LAMAS DE MOURO (19752001) - Livros das Sessões da Junta da Freguesia de Lamas de Mouro (15.01.1975 a 14.05.2001). S/cota. 


\section{PATRINIONIO MIUSICAL DE ÉVORA NO INÍCIO DE OITOCENTOS: UN MISERERE DE FRANCISCO IGN ICIO MOREIRA E POSSÍVEIS CONTEXTOS INTERPRETATIVOS}

Musical heritage of Évora at the beginning of the 19th century: a Miserere by Francisco Ignacio Moreira and possible interpretative contexts.

Rita Faleiro

E-mail: ritapfaleiro@gmail.com CESEM - Universidade de Évora 


\section{Resumo}

No Arquivo Musical da Sé de Évora, existe um nome que se assume como um dos principais reformuladores de obras musicais aí presentes: fala-se de Francisco Ignácio Moreira, entre outros mestre de capela, mestre de solfa e de instrumentos. Neste arquivo, surge-nos pelas suas mãos, um Miserere composto no ano de 1805, e constantemente reformulado: em 1811 é-lhe acrescentado um clarinete e em 1814 um tercetto sobre o $16^{\circ}$ verso.

A presença de datas nestes manuscritos pode tornar-se indicadora de momentos chave na vida da cidade. De facto, 1814 é um ano particularmente activo na cidade no que diz respeito a performances musicais, pelo que o exercício de enquadrar esta obra em possíveis espaços interpretativos se torna relevante para uma melhor compreensão da relação entre património material, imaterial e agentes envolvidos.

Pretende-se assim inserir esta obra no seu contexto geral, articulando-a com espaços e eventos decorridos em Évora ao longo dos nove anos em que esta peça foi sendo modificada.

Palavras-chave: Évora; Século XIX; Miserere; Música Sacra; Francisco Ignácio Moreira.

\section{Abstract}

In the musical fund of the Archive of the Cathedral of Évora, we can find one name that assumes the role of one of the main reformulators of musical pieces from the referred fund: Francisco Ignácio Moreira, chapel master, music master and instrument teacher. It is in this archive that we find, from Moreira, one Miserere composed in 1805 and that was constantly remodeled: in 1811 a clarinet is added, and in 1814 appears one tercetto in the 16th verse.

The fact that we can find dates in these manuscripts can be indicator of key moments in the city's life. In fact, 1814 is one particularly active year regarding musical performances in Évora, reason why this exercise of framing this musical work in some possible interpretative spaces and contexts is particularly important and relevant in order to obtain a better understanding of the relation between material/immaterial patrimony and involved agents.

It is intended to insert this particular musical piece in its general context, coordinating it with spaces and events occurred in Évora throughout the nine years that it was modified.

Keywords: Évora; 19th century; Miserere; Sacred Music; Cathedral of Évora; Francisco Ignácio Moreira. 


\section{Breves apontamcntos} biográficos sobre Francisco Ignácio Morcira

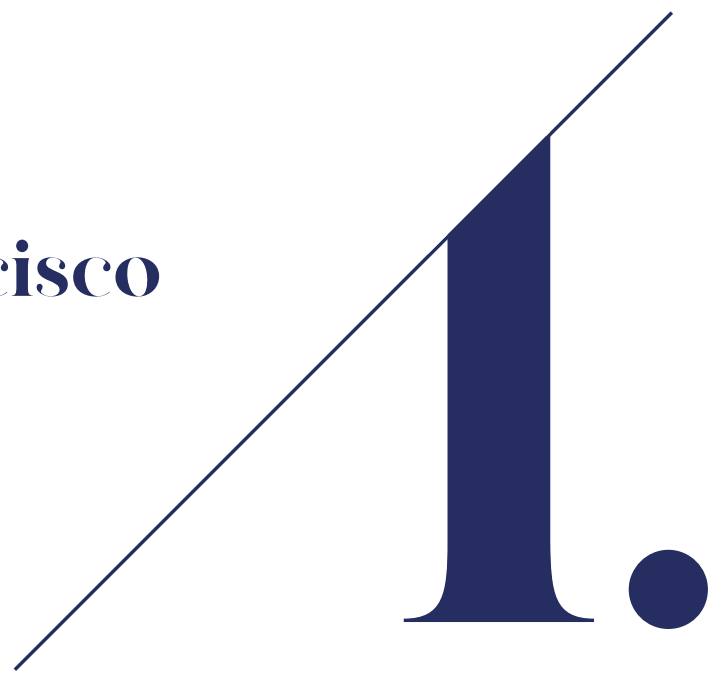

Um dos primeiros passos para quem se quer debruçar sobre a realidade da capela musical da Sé de Évora ao longo dos séculos XVIII e XIX é a leitura e análise das obras base de José Augusto Alegria, que têm vindo, ao longo dos últimos tempos, a ser actualizadas e corrigidas em termos dos dados apresentados.

Esta situação ocorre devido ao facto de as mesmas apresentarem em si erros, lacunas e omissões que têm, por si só, vindo a constituir-se como um campo de estudo específico. ${ }^{1}$

No âmbito destas obras, das quais se destaca como base inicial o Catálogo das Músicas do Arquivo da Sé de Évora (Alegria, 1973), encontra-se recorrentemente o nome de Francisco Ignácio Moreira, que fazia parte da Irmandade de Santa Cecília a par de outros nomes conhecidos da instituição em causa (como Julião Rosado Tavares, Miguel Anjo do Amaral, André Roiz Lopo, Barnabé Vidal, entre tantos outros).

Os dados sobre esta personalidade estão dispersos por variadíssima documentação, não sendo possível obter dados finais sobre a mesma apenas através da consulta de uma obra ou fonte.

Assim, efectivamente, encontramos algumas informações dispersas pelas obras de Alegria e outras fontes como registos de documentação produzidos pela burocracia da Sé de Évora nos finais do século XVIII e inícios do século XIX. Sabe-se então que Moreira foi Mestre de Capela, Mestre de Solfa e Mestre de Instrumentos no ano de 1812: "O mestre de capela é, nesta altura, o P. Francisco

1

A este respeito, e como exemplo, veja-se o trabalho [no prelo] "Os salmos concertados do Arquivo da Sé de Évora entre a segunda metade do século XVIII e início do século XIX ». 
Inácio Moreira, nome já conhecido como rabequista e organista" (Alegria, 1973, 113). Não obstante, já desde 1779 que o seu nome aparece como primeiro rabeca, e, a partir de 1785, acumula a função de organista. Isto mantém-se até 1791/92, aquando da sua posição segundo organista da Sé, com obrigação de ensinar os Meninos do Coro, recebendo para isso noventa mil réis. Um pouco mais tarde, nas folhas de ponto (registos nos quais se apontavam as faltas cometidas pelos músicos, e penalidades associadas às mesmas) do quartel de Setembro de 1800 o seu nome aparece no lote de organistas, não especificando se era primeiro ou segundo - indica, no entanto, que foi penalizado em 50 réis. Em 1812, encontramos o seu nome como Mestre de Capela, aparecendo uma vez mais a efectiva obrigação de ensinar solfa e instrumentos aos Moços de Coro; pelo exercício destas funções, Moreira receberia 200.000 réis. Esta situação repetir-se-ia sem mudanças no ano de 1815, ano de sede vacante (Alegria 1997, 192-194).

Há mais documentação que nos trazem dados mais específicos sobre Moreira. É pelas referências que aparecem em testamentos ou processos de genere que ficamos mais conscientes das relações familiares de Francisco Ignácio Moreira: filho de Luís Moreira e de Maria de Jesus, os seus avós paternos eram Manuel Folgado e Catarina Maia, ao passo que os seus avós maternos eram Matias de Almeida e Mariana de Jesus.

Toda a família dos Moreira parece ter tido uma relação muito especial com o serviço musical prestado a esta instituição e com os seus quadros profissionais. É através, uma vez mais, da consulta aos índices dos processos de genere disponibilizados e a referências dispersas por outras obras, que ficamos a saber que Ignácio Moreira era irmão de José António Moreira, tenor e compositor na catedral (estando-lhe associados, pelo menos, dois Credos entre outras obras), e tio de Carlos Francisco Assis Moreira, também ele associado como compositor nesta mesma instituição. Este último nome, ainda que esteja omisso o apelido Moreira, é sem dúvida o mesmo que aparece referido nas obras base de José Augusto Alegria como sendo o responsável pela composição de um Dixit Dominus em 1805, e a sua produção engloba ainda várias obras como uma Missa Concertada a 4 vozes, um Credo (1806), um Magnificat, um hino, um Te Deum e um Miserere - sendo que esta última obra vem inclusivamente a ser alvo do punho de Francisco Ignácio Moreira.

No entanto, na questão da pesquisa biográfica destes nomes associados à história local de Évora e, por inerência, à da sua Catedral, não é possível esquecer um conjunto de outras fontes bibliográficas que se podem revelar de particular importância. É o que acontece com obras como os diversos dicionários biográficos da época; neste âmbito, destaca-se a obra ímpar de Ernesto Vieira, Dicionário biográfico dos Músicos Portugueses. É nesta obra que se encontra uma referência a Moreira, mestre de capela da Catedral de Évora no final do século XVIIII. Porém, se este dado está correcto, visto que Moreira ocupou efectivamente esta posição como já se viu, a referência ao nome que nos aparece em Ernesto Vieira está 
errada, já que este autor nos fala não de um Francisco Ignácio Moreira mas sim de um Francisco Manuel Moreira, dizendo que foi o autor de um Ecce Sacerdos (antífona por tradição executada, entre outras ocasiões, aquando da recepção de um novo bispo) datado de 1803 e dedicado ao arcebispo Frei Manuel do Cenáculo. O papel de Frei Manuel do Cenáculo é um papel de especial importância, já que foi uma das mais importantes referências da cultura portuguesa dentro do Iluminismo, tendo sido responsável pela criação de bibliotecas, recolha de livros, construção de uma ideia de património e identidade. Não surpreende, portanto, que seja considerado como uma referência nos círculos políticos e intelectuais portugueses, de acordo com as palavras de Maria Luísa Cabral. No que diz respeito à sua carreira dentro da Igreja, adiante-se que foi nomeado, em 1768, Provincial da Ordem Terceira de São Francisco, em 1770 bispo de Beja e, em 1802, Arcebispo de Évora - situação esta que terá estado, por suposto, na base da composição por parte dos músicos da casa de obras comemorativas para serem executadas na Sé aquando dos festejos e recepções. O papel de Frei Manuel do Cenáculo no contexto da cultura eborense é ainda importante no sentido em que é da sua lavra a fundação da actual Biblioteca Pública de Évora no edifício erguido no século XVII, sobre os restos do antigo Castelo situado nas dependências da Catedral e que primeiramente albergou, a partir de 1666, uma das mais importantes instituições de ensino musical em Évora: o Colégio dos Moços de Coro (Alegria, 1977, 193; Barata 1874, 62), instituição com um sistema de ensino muito organizado e específico, instituído pelo Cardeal D. Henrique em 1552, que receberia os jovens a partir dos 9 ou 10 anos de idade até à altura da mudança de voz (Henriques, 2018, 79); pelos 17 ou 18 anos, ser-lhes-ia dada a possibilidade ingressarem no estudo da Teologia (que, na Universidade de Évora, levaria cerca de 4 anos) ou de seguir outra carreira.

No entanto, e regressando ainda à questão desta composição do Ecce Sacerdos indicado na obra de Vieira, não se encontra qualquer referência à composição, por parte de Moreira (nem de nenhum dos vários Moreira presentes no catálogo, para ser mais específica), desta obra em particular. Não sendo certa a razão pela qual isto possa ter acontecido, uma das prováveis leituras que se podem colocar prende-se à já conhecida tendência de haver um conjunto de erros e omissões relativamente à realidade dos manuscritos, indicando obras a mais, a menos, ou diferentes em relação às cotas fornecidas. Assim, no contexto do estado de organização e catalogação efectuadas por José Augusto Alegria ao Arquivo da Sé de Évora, não é de excluir a possibilidade de que este Ecce Sacerdos tenha efectivamente existido e sido da lavra de Francisco Ignácio Moreira mas que, até à data, esteja debaixo de uma cota distinta que não a mostre de forma inequívoca - ou mesmo que esteja enquadrada dentro de outra cota, junto a outras obra sem que tal dado seja, até ao momento, conhecido. Por outro lado, podemos também perceber que Vieira se enganou na correcta indicação de Moreira, já que da consulta da restante documentação não se consegue encontrar a existência de qualquer Manuel Moreira. 


\section{O Miscrerc de Morcira c a sua ligação a Évora}

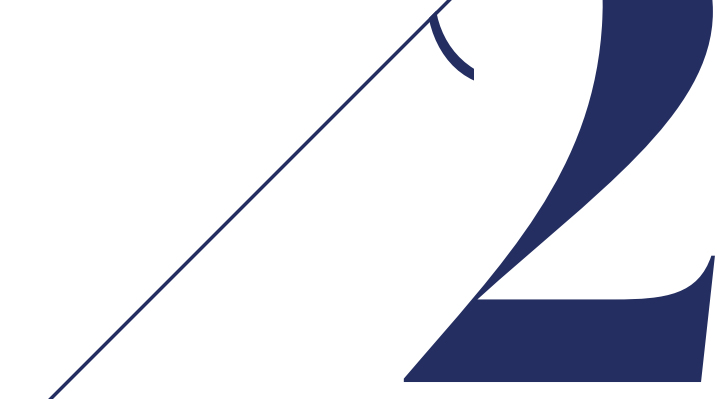

No período cronológico que compreende a segunda metade do século XVIII e primeiras décadas do século XIX, no fundo musical da Sé de Évora encontramse (de acordo com a listagem de José Augusto Alegria) mais de duas dezenas de referências a este salmo em particular - o Miserere Mei Deus, salmo 50 (ou 51, de acordo com a numeração utilizada.

Não obstante, é sempre necessário recordar-se que este número nunca poderá ser considerado final uma vez que existem diversas situações em que Alegria não identifica correctamente quer a tipologia quer o número de obras existentes em cada cota. É a situação que ocorre, meramente a título de exemplo, com a cota atribuída a um Miserere de Julião Rosado Tavares; sendo certo que Alegria (1973, 37) na cota que nos apresenta nos fala em três obras dentro desta cota (citando, "Miserere a 3 coros, 12 e 8 vozes (1767)"), na realidade as três obras constantes desta cota são distintas: efectivamente, não encontramos três versões da mesma obra mas sim duas obras a três coros de Julião Rosado Tavares e um arranjo para apenas dois coros de Francisco José Perdigão, mestre de capela e da claustra a partir de 1785. Outros exemplos de incorrectas identificações encontram-se nas cotas121 de Ferreira de Lima ou 255 de D. António Sá Tedeschi. ${ }^{2}$

É precisamente dentro do âmbito desta incorrecção de cotas que nos deparamos com o caso do Miserere de Moreira que aqui se aborda. Se no catálogo de Alegria nos deparamos com a existência de cinco cotas referentes a cinco Misereres, na realidade duas destas cotas, por razões que não são claras, referem-se à mesma obra - a aqui apresentada, e composta em 1805, altura em que era arcebispo de Évora Frei Manuel do Cenáculo, como anteriormente foi referido.

\footnotetext{
2 A este respeito, consulte-se Faleiro, Rita, "Uma apresentação dos miserere do Arquivo da Sé de Évora”, disponível em http://www.incomunidade.com/v75/art_bl.php?art=437
} 
Liturgicamente, este é um dos salmos mais conhecidos que encontra a sua finalidade predilecta em todas as ocasiões ligadas a contextos fúnebres e a celebrações da semana santa, com especial incidência no chamado Serviço de Trevas, ofício este enquadrado no tríduo pascal - ponto alto de todo o ano litúrgico, e constituído pelas matinas e laudes de Quinta, Sexta e Sábado Santos (Faleiro, 2019, no prelo).

No entanto, da consulta a mais fontes litúrgicas e fontes de época, constatamos que este salmo era utilizado em mais situações distintas.

É o que nos descreve Frei Veríssimo dos Mártires, Religioso da Terceira Ordem Franciscana em Lisboa. Na sua obra Director Funebre Reformado (Mártires, 1799), obra particularmente destinada às situações ligadas à morte e ao cerimonial a seguir na questão dos moribundos e defuntos, o autor lista-nos as variadíssimas situações em que este texto poderia ser proferido, situações estas que poderiam passar pela distribuição do Sagrado Viático:

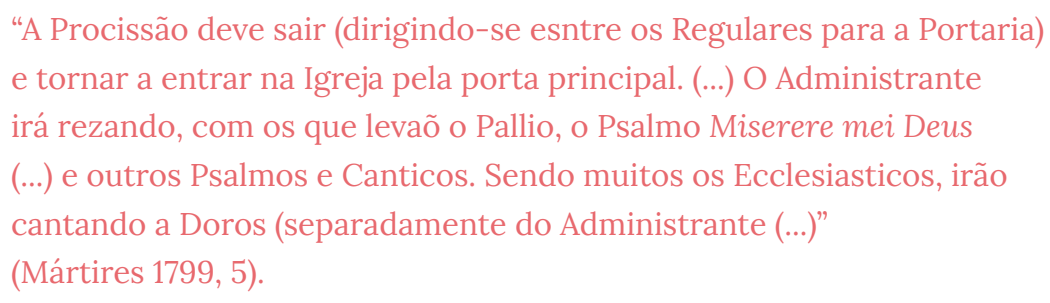

Estas procissões que transportam o sagrado Viático ao leito do moribundo, que (pelo menos no contexto lisbonense) eram espontaneamente geradas, eram por norma anunciadas por uma sineta ou campainha, o que não aconteceria se a mesma tivesse lugar na Quinta-Feira Santa, altura em que este aviso seria dado por uma matraca (Nery 2008, 28; Mártires, 1799, 10).

Pode ainda ser executado aquando do sacramento da Extrema-Unção, enquadrado na sequência dos sete salmos penitenciais: salmos 6 (Domine ne in furore), 31 (Beati quorum remissae), 37 (Domine ne in furore - ainda que o início do salmo seja idêntico, o resto do texto é distinto), 50 (Miserere mei Deus), 101 (Domine exaudi orationem), 129 (De profundis) e 142 (Domine, exaudi orationem meam - mesma situação que acontece com os salmos 6 e 37). Miserere mei Deus pode ainda, de acordo com Veríssimo, ser utilizado no contexto processional do transporte do corpo do defunto à Igreja onde decorreriam as cerimónias fúnebres, no contexto processional do enterro dos Irmãos Terceiros Seculares e nas Laudes dos Ofícios de Defuntos, sendo que nesta ocasião seria precedido e seguido da antífona Exsultabunt Domino ossa humiliatam. As próprias referências ao modo de cantar e executar este texto litúrgico nas Laudes estão bastante regulamentadas e descritas por Veríssimo (1755), que o enquadra após a oração do Pai Nosso e referindo algo bastante importante, já que define sem margem de dúvida a questão de haver a necessidade de se trabalhar com o coro em "alternatim com 
devoção, e com voz triste, e branda (...)" (Veríssimo, 1755, 64).

Veríssimo enquadra ainda o Miserere nas horas menores (prima, terça, sexta, nona), e noutras ocasiões enquadrado por diferentes antífonas - é o caso, por exemplo do Terceiro Nocturno das Matinas de Quinta-Feira Santa (Veríssimo 1755, 152) ou das Laudes de Sexta-Feira Santa (precedido da antífona Proprio Filio e seguido da antífona Anxiátus est super me; Veríssimo 1755, 268)

De acordo com os trabalhos que têm vindo a ser desenvolvidos sobre a questão da produção/composição e existência desta obra no fundo musical de Évora, podemos falar na existência de três tendências gerais no que concerne à estrutura básica destas obras.

A questão da execução em alternatim, descrita por Veríssimo, encontra eco nas obras presentes em Évora; efectivamente, de uma forma geral, e ainda que com algumas especificidades relativamente à utilização do número de coros necessários, todos estes Miserere do período em questão são caracterizados por uma estrutura alternada (baseada na alternância de secções de determinados itens litúrgicos, nos quais se encontram solistas vs. coro, de acordo com Higginbottom), tão típica do estilo concertado, definido por Shrock como "a style of composition during the Baroque era that employed contrasts of smaller and larger performing forces, usually soloist and a few instruments for the smaller forces (generally called concertino), and chorus and full orchestration for the larger forces (called concerto grosso)" (Shrock, 2009, 764). Assim, não é de estranhar que seja esta a prática existente em Évora, sejam estes contrastes baseados em várias tipologias, como compassos, tonalidades ou sejam eles estabelecidos tendo como base as densidades texturais - aliás, esta é a realidade encontrada noutras obras de época compostas pelos nomes mais conhecidos do panorama musical português ou europeu, como José Joaquim dos Santos, ou David Perez.

É dentro desta análise geral estrutural aos Miserere existentes em Évora no período cronológico referido que nos deparamos com a existência dos chamados misereres abreviados - esta situação é originada pelo facto de, ao contrário da maior parte das mais de duas dezenas de obras que constituem esta amostra de estudo, algumas destas peças musicais apresentarem apenas alguns versos colocados em música ao invés de apresentarem o típico verso sim verso não. É o caso de obras como a de Inácio António Ferreira de Lima, antigo monge jerónimo em Lisboa que foi Mestre de Capela em Évora entre 1816 e 1818, e o caso precisamente do Miserere de Moreira apresentado neste trabalho: ${ }^{3}$

3 Torna-se imperioso referir que, nesta obra, o primeiro e último versos não são trabalhados por completo. No primeiro verso, trabalha-se apenas o primeiro hemistíquio e no último trabalha-se apenas o segundo hemistíquio, sendo esses os textos que constam desta tabela. 


\begin{tabular}{lll}
\hline Verso & Texto & Tradução \\
\hline \multirow{2}{*}{$\mathbf{1}$} & Miserere mei, deus: secundum & Tem misericórdia de mim, \\
& magnam misericordiam tuam & $\begin{array}{l}\text { Deus, segundo a tua } \\
\text { misericórdia infinita }\end{array}$ \\
\hline
\end{tabular}

\begin{tabular}{lll} 
Tibi soli peccavi, et malum & $\begin{array}{l}\text { Pequei somente contra ti, } \\
\text { pratiquei o que é mau aos teus } \\
\text { sermonibus tuis, et vincas cum } \\
\text { judicaris. }\end{array}$ & $\begin{array}{l}\text { olhos: tens razão, portanto, ao } \\
\text { falar, e tua vitória se manifesta } \\
\text { ao julgar. }\end{array}$ \\
\hline $\mathbf{8}$ & $\begin{array}{l}\text { Auditui meo dabis gaudium et } \\
\text { laetitiam: et exsultabunt ossa } \\
\text { humiliata. }\end{array}$ & $\begin{array}{l}\text { Faz-me ouvir o júbilo e a } \\
\text { alegria: e dancem os ossos que } \\
\text { esmagaste. }\end{array}$ \\
\hline & $\begin{array}{l}\text { Redde mihi laetitiam salutaris } \\
\text { tui, et spiritu principali } \\
\text { confirma me. }\end{array}$ & $\begin{array}{l}\text { Devolve-me o júbilo da tua } \\
\text { salvação: e que o Espírito } \\
\text { generoso me sustente. }\end{array}$ \\
\hline & $\begin{array}{l}\text { Quoniam si voluisses } \\
\text { sacrificium, dedissem utique; } \\
\text { holocaustis non delectaberis. }\end{array}$ & $\begin{array}{l}\text { Pois tu não queres um } \\
\text { sacrifício: um holocausto não } \\
\text { te agrada. }\end{array}$ \\
\hline 19 & $\begin{array}{l}\text { Tunc imponent super altare } \\
\text { tuum vitulos. }\end{array}$ & $\begin{array}{l}\text { E em teu altar se oferecerão } \\
\text { novilhos. }\end{array}$ \\
\hline
\end{tabular}

No que concerne às opções instrumentais, Alegria fala-nos de fagotes e violoncelos obrigados (conclusão a que se chega através da comparação entre as duas cotas que contêm esta obra, já que numa apenas se fala em fagotes e noutra apenas em violoncelos); é então através do contacto directo com o manuscrito que nos apercebemos que a estes, acresce um acompanhamento e um clarinete. Não é irrelevante a questão de nos surgir a indicação obbligato. Intui-se que este acompanhamento, se a ele juntarmos a indicação obbligato, seja um órgão, já é que é habitual no século XVIII esta conjugação, designando uma parte completamente escrita ao invés de um baixo figurado. A própria opção de se escrever os violoncelos de acordo com esta técnica não parece ser irreflectida, já que a utilização, no século XIX, de violoncelos obrigados pode indicar um contexto de melancolia. Certo é que Fuller nos apresenta esta teoria, ou proposta, num contexto mais ligado à questão da ópera romântica; porém, devemos ter em mente que muita da música sacra composta e realizada nesta época acabava por ter elementos muito ligados à questão operática: linhas melódicas elaboradas, passagens tecnicamente muito virtuosas, secções constituídas claramente por melodia e acompanhamento - elementos que faziam sem dúvida lembrar passagens de música não religiosa mas que impregnavam as composições sacras da época. Assim, não é irrelevante estabelecer-se uma ponte entre estes 
contextos mais melancólicos e o sentido geral deste texto litúrgico em particular - que, recordemos, está indubitavelmente associado a contextos pesarosos como os da Semana Santa e os contextos funerários, e que conteriam em si toda a produção de um contexto sonoro.

Uma das principais características desta obra é precisamente o facto de nos oferecer uma cronologia da sua vida. Tendo sido então composta no início do século XIX, 1805, aparecem duas datas mais que se tornam indicativas de momentos chave para os quais esta obra pode ter sido rearranjada.

Cabe aqui recordar que, à semelhança do que acontece num panorama nacional, em Évora encontramos claramente a tendência de se escrever música que detenha um carácter funcional, isto é, que possa ser reaproveitada de acordo com a ocasião ou funcionalidade para a qual seja requerida.

Num contexto mais amplo, esta questão do reaproveitamento de obras musicais era geral. Compunha-se de forma funcional, sendo habitual reaproveitar-se músicas pré-existentes que fossem reformuladas de acordo com os momentos que assim o exigissem; veja-se o que acontece, meramente a título de exemplo, com obras de Miguel Anjo do Amaral, obras de Julião Rosado Tavares, ou obras de Carlos Francisco de Assis Moreira, todas elas compostas e posteriormente rearranjadas quer pelo mesmo compositor quer por um compositor diferente. Está-se portanto na presença de um património musical em constante mutação, em constante evolução, que se vai adaptando aos quadros necessários sem que por essa razão perca o seu valor intrínseco - diversas celebrações litúrgicas.

Esta é uma obra paradigmática já que pelo facto de nos apresentar três datas no manuscrito nos permite articulá-la com eventuais vivências da cidade:

\begin{tabular}{rll}
\cline { 2 - 3 } & Ano & Evento \\
\cline { 2 - 3 } & $\mathbf{1 8 0 5}$ & $\begin{array}{l}\text { Composição da obra, sob arcebispado de Frei Manuel do } \\
\text { Cenáculo. Fundação da Biblioteca Pública de Évora }\end{array}$ \\
\cline { 2 - 3 } $\begin{aligned} \text { Esboço } \\
\text { cronológico- } \\
\text { biográfico do } \\
\text { Miserere de }\end{aligned}$ & $\mathbf{1 8 1 1}$ & $\begin{array}{l}\text { Adição de um clarinete; publicação dos estatutos da Biblioteca } \\
\text { Pública de Évora }\end{array}$ \\
\cline { 2 - 3 } $\begin{aligned} \text { Francisco Ignácio } \\
\text { Moreira }\end{aligned}$ & & $\begin{array}{l}\text { Adição de um tercetto sobre Quoniam si voluisses, } \\
\text { reformulando a versão original; morte de Frei Manuel do } \\
\text { Cenáculo (entre outros eventos). }\end{array}$ \\
\cline { 2 - 3 } & &
\end{tabular}

Atentando-nos nas datas presentes na vida desta obra, conseguimos perceber que todas elas se inserem num início conturbado do século XIX. Efectivamente, os anos iniciais do Oitocentos Português foram marcados por sucessivas guerras, tensões e invasões ao território, para além de dificuldades originadas por questões climatéricas, questões de maus anos agrícolas, carências a nível 
alimentar e fomes. Juntando-se todo este quadro ao contexto da Guerra das Laranjas e da Guerra Peninsular, pode-se perceber que o início do século XIX era apenas apropriado aos pedidos e súplicas por clemência divina, devido às consequências graves em termos populacionais, sociais e mesmo demográficas. De acordo com Fernando de Sousa, citado por Faustino, poder-se-ia mesmo questionar "o que era Portugal por essa altura, senão um país de pobres, onde a miséria é geral!" (Faustino, 2008,13).

Em 1801, vive-se um conflito - a chamada Guerra das Laranjas, de curta duração - que opõe Portugal a Espanha e França; Portugal vê-se invadido por forças castelhanas em maio desse ano, precisamente na zona adjacente a Évora: bloqueia-se a praça de Elvas atacam-se as forças portuguesas em Arronches, e em maio avança-se para Olivença. Como consequência, este conflito que termina com a derrota de Portugal na Europa leva igualmente à perda definitiva de parte de território nacional, já que Olivença é cedida por Portugal a Espanha através do Tratado de Badajoz, aprovado a 6 de Junho de 1801 (Neves, 2010, 71).

Em 1805, se a nível local se destaca a fundação da Biblioteca Pública de Évora, através de Frei Manuel do Cenáculo, a nível internacional (nunca esquecendo que os acontecimentos políticos e estratégicos internacionais acabam por ter, inevitavelmente, repercussões a nível nacional), destaca-se a vitória de Napoleão Bonaparte e das forças militares francesas na Batalha de Austerlitz. Não parece irrelevante a composição de um Miserere, uma obra a implorar pela misericórdia divina, precisamente no ano em que as tropas francesas conseguem uma tão importante vitória - efectivamente, o sentimento nacional para com a nação francesa era de animosidade, já que se vivia debaixo do domínio napoleónico um clima de fingida amenidade (Neves, 2010, 71), e, como o futuro o viria a demonstrar, as tropas francesas dariam efectivamente razões para instaurar o medo na população.

De 1806 em diante, Évora vê-se no centro dos acontecimentos ligados à questão das guerras e invasões napoleónicas, sendo que logo em 1807, no seguimento da assinatura do tratado de Fontainebleau e do ultimato de Bonaparte e de concentração de tropas francesas junto à fronteira entre Espanha e Portugal, assiste-se à retirada da Corte para o Brasil, originando um trono português ocupado por um Conselho de Regência. É neste contexto que se pode enquadrar a resistência portuguesa ao domínio francês, facto exacerbado ainda por determinações levadas a cabo por Junot, como o decreto de proibição de ajuntamentos e o desarmamento das tropas portuguesas (Neves, 2010, 70-71).

É, no entanto, em 1808 que Évora se vê assolada por um ataque, no decorrer da segunda invasão francesa, que esteve no epicentro de uma das maiores crises de mortandade pelas quais a cidade passou, para além de todos os saques e pilhagens que vieram com esta invasão associados. A título de exemplo, refira-se a destruição e saque de uma grande parte da colecção da biblioteca pública (Vaz, 
2012, 1) Se é certo que neste ano celebrações musicais aconteceram na Sé de Évora (como a execução de um Te Deum, ou missas cantadas) em agradecimento por eventos como o restabelecimento da monarquia portuguesa (Espanca, 1957, 55-56), o que também é certo é que 1808 foi um ano particularmente violento para a cidade. De 29 a 31 de Julho, Évora esteve no epicentro de um dos maiores ataques e cercos de que há memória, sendo variadíssimas as referências à violência perpetrada contra a população - civis ou religiosos. Há que referir que no contexto desta invasão, a população uniu-se para defender a cidade, tomando como armas o que fosse possível, já que a pena para posse de arma de fogo era a morte, já que as armas de fogo se destinavam ao exército (Espanca 1957, 67).

João Limpo Pimentel (entre outros, Cavaleiro da Ordem de Cristo, secretário de D. Joaquim Xavier Botelho de Lima e prior da paróquia de S. Pedro em Évora, tendo falecido em Junho de 1823) foi testemunha ocular da tragédia. Citando-o, Espanca $(1957,71)$ mostra um quadro vivo de palavras que nos fazem ter uma breve noção do horror vivido pela população eborense:
"O sanhudo Loison tinha ordenado ao seu exército, que logo que ganhassem a cidade a pusessem no mais vivo rigoroso e cruel saque: assim mesmo se cumpriu, pois que as tropas sem esperarem sinal, nem disposição hiam entrando e fazendo um incessante e vivíssimo fogo sobre tudo quanto aparecia, sobre portas e janelas, que ao mesmo tempo arrombavam a golpes de ferro e de fogo, sem escapar nem o mais reforçado fecho nem a mais pobre casinha. (...) nada escapou, e todo o espírito vivente que apareceu tudo perdeu a vida (...). Tal era a raiva e a crueldade do inimigo, que a muitos depois de lhes entregarem os seus dinheiros, as suas preciosidades e tudo quanto tinhão ultimamente os matavão por não terem mais que dar. A outros lhes tiravam as vidas depois de os haverem obrigado a presenciarem os excessos de luxúria, e as indiziveis abominações que cometiam com suas mulheres, irmãs e filhas. Tão inaudita desumanidade era a destes raivosos leões, que aos olhos das próprias mãis abusavam de suas filhas, com particular tendência para as menores que brutalmente matavam aos golpes da lascívia. Nos berços e nos colos das desgraçadas mãis trespassavam a ferro os tenros meninos e os levavam espetados nas pontas das baionetas. (...)"

Estas invasões são ainda descritas por José Augusto Alegria $(1973,113)$, que nos diz que a cidade foi saqueada e que se viveram horas dramáticas ou ainda por António Pereira $(1808,16)$, na sua obra de referência Evora no seu abatimento, gloriosamente exaltada:

"Contra os Ecclesisasicos, e Sacerdotes, mostrarão desde a sua entrada hum refinado odio. E tanto, que entre clérigos, e frades matarão trinta e oito, matando igualmente o Excellentissimo Bispo do Maranhão, que por suas letras, e virtudes era geralmente respeitado de todos. E daquelles clérigos, alguns forão públicamente espingardeados, como 
aconteceo a quatro ao chafariz dos Leões, pelo unico delicto de serem Ecclesiasticos.."

Moreira é responsável em pela reformulação de um Miserere a quatro vozes em estilo concertado, precisamente na altura em que, decorrente da primeira invasão francesa, a súplica veiculada por este salmo se coadunava perfeitamente com o drama quotidiano vivido pela cidade, no decurso dos roubos, saques e assassinatos descritos na passagem acima transcrita da autoria de Pereira.

Sendo certo que a obra aqui proposta, composta em 1805, não apresenta qualquer alteração (pelo menos conhecida até ao momento) nos anos críticos de 18081809, a próxima data que nos é dada é 1811, altura em que Moreira acrescenta um clarinete. Contextualmente, há que recordar que a memória dos recentes ataques de 1808 estava ainda tremendamente presente na mente das pessoas; assim, quando em 1810 Massena invade Portugal iniciando a Terceira Invasão Francesa, pode-se intuir-se o medo que grassava de que os anteriores eventos voltassem a acontecer. É no contexto da Guerra Peninsular que o ano de 1811 se revela particularmente interessante no exercício de leitura que possa explicar o porquê de este Miserere ter sofrido uma adição/alteração. Efectivamente, em três períodos diferentes de 1811 (e um período de 1812) a cidade (ou, mais especificamente, a praça) de Badajoz esteve cercada como operação estratégica para que as tropas pudessem então entrar em território nacional; de facto, esta é uma das cidades que está em linha directa para qualquer invasão que se pretendesse efectuar ao território português, a par de Elvas - ambas geograficamente perto o suficiente de Évora para gerar o pânico e assim, uma vez mais, implorar a misericórdia divina.

É neste contexto então que Moreira volta a pegar no seu manuscrito e lhe acrescenta uma inovação - um clarinete. É de se notar que esta não é a única vez que Moreira faz isto; efectivamente, já no ano de 1810, Moreira vai acrescentar este instrumento ao Te Deum composto por Carlos Francisco Assis Moreira - é possível adiantar a hipótese de que esta possa ter sido a obra cantada em Agosto em acção de graças pelo casamento da Sereníssima Princesa com o Infante de Espanha) (Espanca, 1955, 284). O facto de em duas obras tão próximas Moreira ter optado por inserir este instrumento faz considerar, sem sombra de dúvida, que no que concerne ao quadro de músicos profissionais que estavam afectos a Évora, tenha algum clarinetista sido colocado na cidade. Porém, após consulta a documentação criada pela burocracia da Sé de Évora, nos registos de pagamentos a músicos, não nos aparece qualquer indicação de pagamentos ou contratações feitas a clarinetistas; isto está também ligado, sem sombra de dúvida, ao facto de que entre o início do século e os anos de 1812-1813 todos estes registos desapareceram, tendo provavelmente sido destruídos no contexto dos saques e pilhagens levadas a cabo pelas forças francesas no decorrer do ano de 1808. Porém, o facto de quando reaparecem os registos também não surgir qualquer nome de clarinetista associado aos quadros instrumentais faz recordar a posição 
de José Augusto Alegria, que refere já no ano de 1795 a existência de algumas "notícias estranhas por desconformes com os usos e costumes da Sé" (Alegria 1997, 182), entre as quais estaria a referência à necessidade de recorrer a músicos de fora da capela para a execução de determinadas obras (no caso apresentado por Alegria, esta situação terá ocorrido precisamente para reforço do quadro instrumental necessário para um Te Deum de 1795). Alegria fala ainda da questão deste reforço ser possivelmente feito através do recurso a antigos colegiais; não é de descartar esta hipótese, tendo em conta que o ensino ministrado nesta instituição dotava os aprendizes de capacidades musicais e técnicas variadas, que os habilitavam para a correcta execução de instrumentos de diferentes estilos de execução - quando consultamos a documentação da burocracia da Sé, não é raro encontrarem-se referências como "Paulo Jozé músico instrumentista com obrigação de cantar contrabaixo, cantar tenor, ensinar meninos do coro, e na falta do Baixo (instrumento) tocar rabecão" (situação ocorrida entre os anos de 1768 e 1779); o próprio Mestre de Capela da época, Francisco Ignácio Moreira, era versado em dois instrumentos diferentes como foi anteriormente referido - e instrumentos que tecnicamente são bastante distintos, utilizando mecanismos digitais e padrões de dedilhação radicalmente diferentes. Assim, fica a questão em aberto sobre a possível identidade deste clarinetista que a partir de 1810 aparece associado às obras sacras compostas e utilizadas em Évora.

Não existe uma indicação clara de qual o clarinete utilizado em específico nesta obra. Porém, de acordo com o que nos diz Luciano Pereira (2010), o clarinete de cinco chaves foi construído por volta de 1770/1780 e utilizado até ao final de 1830, abarcando assim o período de vida desta obra. No final do século XVIII, aparece então o clarinete em si bemol, e a versão de cinco chaves torna-se o habitual para o período do classicismo, tendo uma sonoridade homogénea e com um timbre brilhante - porém, o contacto com o manuscrito do Miserere de Moreira mostra-nos um instrumento com uma armação de clave semelhante a todo o restante efectivo instrumental; quer isto dizer que a sua afinação estava em Dó, ou seja, natural, o que de acordo com Pereira representa mais brilho sonoro. Até que ponto a adição e utilização de um instrumento com um carácter e timbre sonoro brilhante, inserido numa obra de carácter pesado e fúnebre (o que à partida configuraria uma antítese), terá sido propositada devido à detenção da terceira invasão francesa é uma possibilidade a considerar - se por um lado se invoca misericórdia divina para que os eventos anteriores não voltem a cair sobre a população eborense com uma gravidade tamanha, por outro lado cria-se um ambiente sonoro mais brilhante e timbricamente mais preenchido devido ao sucesso em travar esta nova tentativa de invasão do território nacional.

A utilização de clarinetes no contexto da música portuguesa da época é recorrente; recorde-se o exemplo de Marcos Portugal, aluno do Seminário da Patriarcal desde os seus nove anos, que no seu hino para a aclamação de D. João VI, composto em 1817, utiliza quatro clarinetes. De acordo com António Marques, citado por Alberto José Pereira Pacheco, desde 1813 que a Orquestra da Capela 
Real do Rio de Janeiro tinha a seu uso precisamente este número de clarinetes - ou seja, esta é uma opção estilística perfeitamente enquadrada nas correntes estilísticas do período não apenas em Portugal mas num contexto luso-brasileiro.

A última data apresentada nesta obra é 1814. Este é um ano particularmente activo no que diz respeito a possíveis eventos contextuais para a prática e performance desta obra. É neste ano que Moreira acrescenta (ou melhor, reformula), um tercetto sobre o verso Quoniam si voluisses - sendo certo que este verso já existia colocado em música na versão original, há algumas diferenças interessantes entre as duas versões no que concerne à densidade textural utilizada. Na versão original, encontramos uma utilização marcadamente policoral, que divide a responsabilidade de execução do texto entre si, sendo acompanhado com violoncelo, clarinete, fagote e acompanhamento (órgão). Já na reformulação, Moreira opta por reduzir a densidade textural e utilizar apenas duas vozes soprano e alto - com um carácter solista, e quatro vozes com um carácter de eco, especificamente indicado pelo próprio compositor; estas vozes de eco surgem apenas como reafirmação de certos vocábulos, chamando para eles a atenção mas não retirando qualquer protagonismo ao soprano e alto solistas, que nos apresentam - como é típico para a época - uma linguagem musical repleta de ornamentação, apogiaturas e grupetos.

O que Moreira opta por retirar neste tercetto de 1814 é a utilização do clarinete (presente na versão original de 1811), reduzindo assim quer a questão tímbrica mais sonora que eventualmente possa estar associada à vitória da detenção da terceira invasão, como previamente referido, quer a própria densidade orquestral, que aqui passa a ser baseada em dois fagotes, violoncelo e acompanhamento. Tudo isto concorre para que a atenção se baseie sobretudo nas vozes solistas, embora haja a referir que a dificuldade de que a escrita violoncelista tem nesta versão do terceto é incomparavelmente maior que na versão original. Uma vez mais, isto levanta a questão da identidade do violoncelista responsável pela sua execução. Porém, e se ao contrário dos anos de 1811, para 1814 temos acesso aos nomes constituintes do quadro musical da capela, a verdade é que estes nomes não se referem a nenhum violoncelista, pelo que é de se supor que, à semelhança do que aconteceu em 1811 com o clarinetista, em 1814 tenha sido necessário recorrer a algum músico externo à capela. Assim, os dados que temos para o ano de 1814 (infelizmente, para o segundo semestre de 1814 não existem registos) em termos da constituição da capela musical eborense são os seguintes:

\begin{tabular}{ll}
\hline Função/Ano & 1813-1814 \\
\hline $1^{\circ}$ capelão & Pe. Jozé Agostinho da Silveira \\
\hline $2^{\circ}$ capelão & Pe. Francisco Moreira \\
\hline Mestre da capela & Pe. Francisco Ignácio Moreira \\
\hline $\begin{array}{l}\text { Mestre da capela } \\
\text { aposentado }\end{array}$ & $\begin{array}{l}\text { Pe. Francisco Jozé Perdigão (procurador Miguel } \\
\text { Anjo do Amaral) }\end{array}$ \\
\hline
\end{tabular}




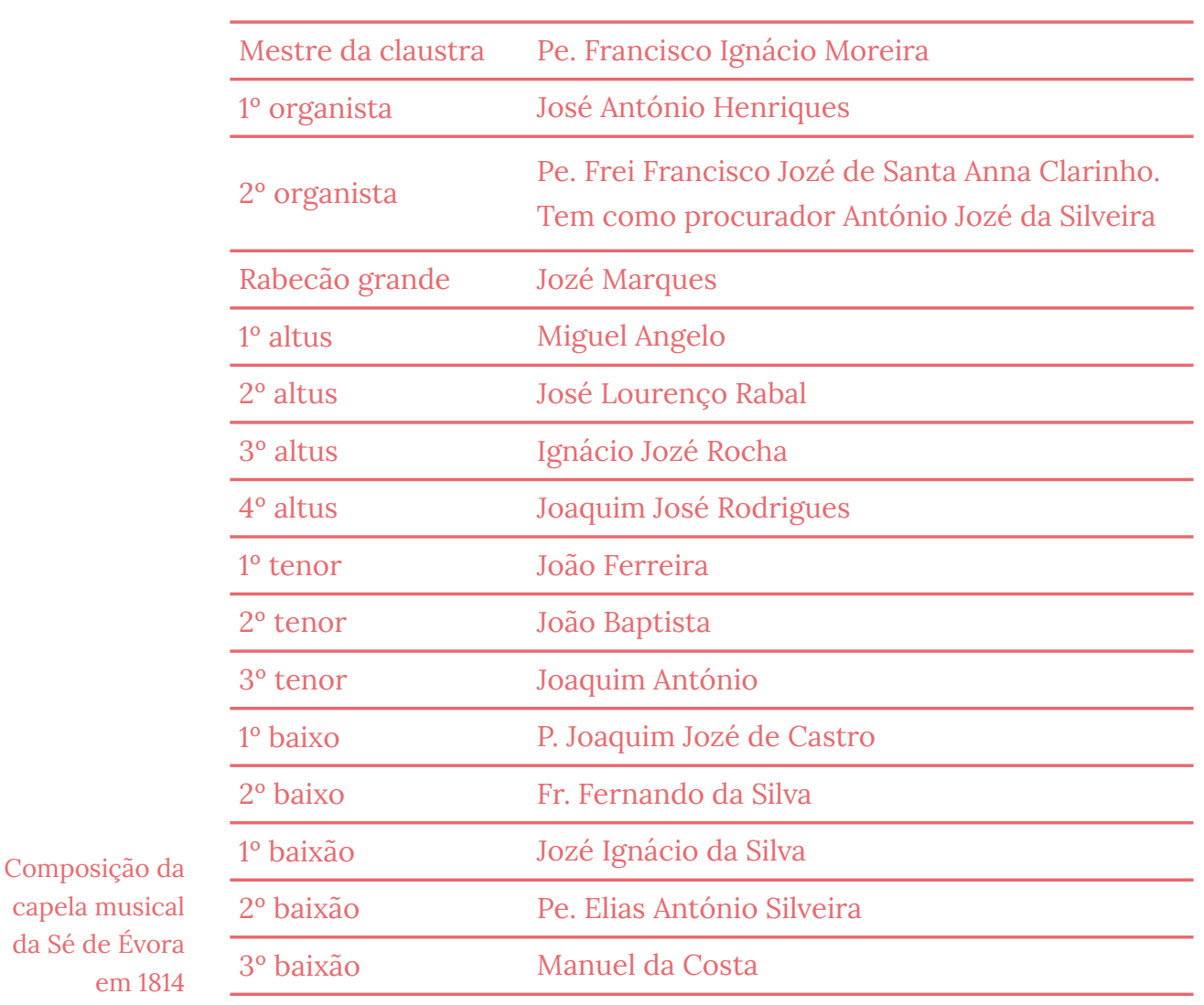

Uma das leituras propostas para este reduzir de densidade orquestral está ligada aos diversos acontecimentos de cariz pesaroso que aconteceram em 1814, última data em que esta obra é reformulada.

Falando apenas do contexto de Évora, relembre-se que 1814 é não apenas o ano em que morre Frei Manuel do Cenáculo, cujo papel fundamental em Évora é já sobejamente conhecido, como também é o ano em que se procede à cerimónia de transladação das ossadas dos eclesiásticos mortos e fuzilados aquando do fatídico ano de 1808. Assim, não é de admirar que seja este o ano em que Moreira não apenas reformula o Miserere do seu sobrinho, Carlos Francisco de Assis Moreira (composto em 1809, tão pouco tempo depois da calamidade que se abateu sobre a cidade), como também seja o ano em que reformula a sua própria obra.

O facto de ao longo da sua obra - por tradição associada a momentos de pesar, de luto, momentos fúnebres - Moreira ter optado por colocar em música versos com um carácter menos pesaroso (recorde-se a tradução dos versos colocada no ponto anterior) não deixa de ser curioso; efectivamente, o compositor opta por neste exemplar de património imaterial trabalhar os conceitos mais ligados a aspectos positivos como a alegria ou a salvação.

Torna-se inevitável não fazer corresponder todas estas opções estilísticas e musicais às cerimónias de transladação há pouco referidas, já que estes versos, ainda que incluídos numa obra pertencente a uma categoria já de si tão pesada 
quanto o é a categoria dos salmos penitenciais, acabam por dar alguma esperança ao se falar da vida eterna.

Esta questão faz particularmente sentido quando recordamos os dados fornecidos por Pereira $(1808,18)$ : na sequência à invasão à cidade de Évora, a mortandade ascendeu a mais de mil pessoas: 232 na cidade e mais de oitocentas nos campos circundantes, pelo que a súplica a Deus era o caminho plausível.

É então no ano de 1814 que estes homens, mortos às mãos dos franceses poucos anos, são transladados para várias igrejas a 3 de julho. No Arquivo Municipal de Évora, encontram-se os nomes das ossadas que estivera no centro destas cerimónias: José Francisco Xavier da Costa, prior da Igreja de Salvador de Odemira; João António de Sá, beneficiado curado da Colegiada de Santo Antão; João Alberto, pároco da freguesia de Santa Susana, Redondo; e ainda Sebastião José da Rocha, associado à paróquia de Santiago.

Todos estes nomes se referem a párocos fuzilados e transladados, nesta data para a Igreja de São Bartolomeu. Geograficamente, esta igreja localiza-se a pouca distância da Porta de Avis e foi fundada nos inícios do século XVII (1612) em terrenos que o sacerdote quarternário da Sé, Laureano Martins, doou para o efeito, tendo para isso sido ajudado pelas esmolas oferecidas pelos fiéis (Fialho, 1729, 225); encontramos ainda os nomes de José do Nascimento Pereira e José Perdigão, bem como referências às diversas cerimónias oficiais nas quais se cantaram Matinas e Laudes, para além da realização de uma Missa Cantada (cada uma destas ocasiões devidamente regulamentada e com ordens bem estabelecidas e coerentes), sabendo-se que estes ossos foram depositados na Capela de Santa Ana, com um retábulo composto maioritariamente em estilo barroco e que posteriormente passou a apelidar-se de Capela de Santa Teresinha. ${ }^{4}$ Esta informação não é irrelevante sobretudo se pensarmos que esta capela está enquadrada na Igreja de Santo Antão, uma das igrejas mais importantes no contexto religioso-musical da cidade de Évora imediatamente a seguir à Sé de Évora (Henriques, 2017, 356). Efectivamente, Santo Antão, colegiada beneficiados, funcionava como um anexo à própria Sé. Pelo facto de, de acordo com o que Fonseca $(1728,218)$ nos diz, os seus beneficiados e vigários terem como obrigação o coro e o cântico de variados ofícios quer do Dia Litúrgico quer das Missas quando necessário, não é irrelevante pensar-se que Santo Antão pode ser sido um dos espaços possíveis para a execução do Miserere de Moreira, criando assim uma tríade bastante forte entre obra-espaço-compositor num momento específico da vida da cidade: as cerimónias fúnebres do dia 3 de Julho de 1814. Sendo o Miserere um tópico tradicionalmente relacionado com o contexto fúnebre, parece inegável encontrar-se nestas transladações o contexto exacto da envolvente musical desta 
performance, em contexto processional ou cerimonial, já que 1814 foi, pelo que já se percebeu, um ano particularmente activo no cerimonial fúnebre eborense: tanto Cenáculo, figura de importância extrema na cidade, como os homens da Igreja que perderam a vida anos antes, vítimas de guerras e políticas bélicas entre países, estiveram no epicentro de cerimónias fúnebres variadas, contexto preferencial para a execução deste salmo penitencial.

A percepção da realidade musical de uma época não se encontra apenas através do trabalho de contacto com os manuscritos musicais. Deste tipo de trabalho, retiram-se, sem dúvida dados importantes relativos a questões formais, estilísticas, comparativas ou mesmo analíticas. Porém, uma obra musical é um produto cultural, um exemplo de património (i)material (consoante se tenha em conta meramente a questão física a partitura ou o próprio momento de execução, tão localizado no tempo, tão único e irrepetível que se torna inevitavelmente imaterial) que não está desenquadrado - antes bem pelo contrário - do contexto para o qual foi criado e destinado. Por essa mesma razão, estes exercícios exploratórios de leituras iniciais relativas aos hipotéticos contextos históricos e contextos locais onde - e para onde - foram realizadas e conceptualizadas estas obras musicais eborense sejam tão importantes, já que contribuem para uma melhor e mais completa compreensão e visão da geografia sonora e musical própria do contexto da cidade e dos seus momentos e cerimónias específicas. 


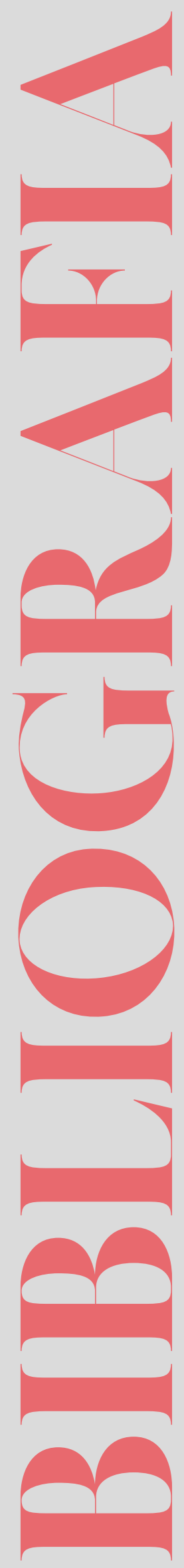

Alegria, J. A. (1973a). Arquivo das músicas da Sé de Évora: catálogo. Lisboa, Fundação Calouste Gulbenkian.

Alegria, J. A. (1973b). História da Escola de Música da Sé de Évora. Lisboa, Fundação Calouste Gulbenkian.

Alegria, J. A. (1997). O colégio dos moços do coro da Sé de Évora. Lisboa: Fundação Calouste Gulbenkian.

Barata, A. F. (1874). Esboços chronologico-biographicos dos Arcebispos da Egreja de Évora. Imprensa Litteraria.

Espanca, T. (1955). Efemérides Eborenses - 1791 - 1831. A Cidade de Évora: Boletim de Cultura da Câmara Municipal (1 ${ }^{a}$ Série), 37, 269 309.

Espanca, T. (1957), Évora na invasão francesa de 1808; A Rainha D. Leonor e a Misericórdia de Évora; José de Escobar, pintor quinhentista - O retábulo da Misericórdia de Mora. A Cidade de Évora: Boletim de Cultura da Câmara Municipal (1 ${ }^{a}$ Série), 39, 41 - 138.

Fonseca, F. D. (1728). Évora gloriosa. Epilogo dos quatro tomos da Evora Illustrada que compoz o R PM Manuel Fialho da Companhia de JesuEscrita, acrescendata e amplificada pello P Francisco da Fonseca da mesma Companhia, Rome. Na Officina komarekiana.

Henriques, L. (2017). A paisagem sonora de Évora no século XVII: Perspectivas a partir da actividade musical das instituições religiosas da cidade. In Book of Proceedings II International Congress on Interdisciplinarity in Social and Human Sciences (pp. 355-359). Research Centre for Spatial and Organizational Dynamics.

Henriques, L. (2018). A nova capela-mor setecentista da Catedral de Évora: Uma abordagem ao seu impacto na atividade musical de Pedro Vaz Rego e Ignácio António Celestino. Arte y Patrimonio: Revista de la Asociación para la Investigación de la $\mathrm{H}^{a}$ del Arte y del Patrimonio Cultural" Hurtado Izquierdo", (3), 77-92.

Higginbottom, E. Alternatim'. Grove Music Online. Oxford Music Online. Oxford University Press http://www. oxfordmusiconline. com/subscriber/article/grove/music/00683 (accessed Augst 12, 2018). 
http://revista.brasil-europa.eu/142/Cabo-Verde-Miserere.html accedido a 23 de julio de 2018

https://digitarq.adevr.arquivos.pt/details?id=1001130, accedido a 14 de septiembre de 2018

Maria Luísa Cabral, CENÁCULO, Frei Manuel do (Lisboa 1724-Évora 1814). [Em linha]. Consultado a 25 de marzo de 2019, acessível em http://eve.fcsh.unl.pt/content.php?printconceito=1043

Mártires, V. D. (1755). Director ecclesiastico das ceremonias da Cinza, Ramos, e de toda a Semana Santa, conforme as rubricas do Missal Romano, e Decretos da S. Congregaçaõ de Ritos, com todo o Cantochaõ, que nos sobreditos dias se deve cantar. Lisboa: Na officina de Joseph da Costa Coimbra.

Mártires, V. D. (1780). Director funebre reformado para se officiar, e administrar com perfeição o sacrosanto viatico, extrema-unção aos enfermos, officio de defuntos, procissão das almas, e outras funções pertencentes aos mortos com o proprio canto, que nellas se deve observar, segundo o Ritual Romano de Paulo V, Decretos Apostolicos, etc... Lisboa : Na Officina Patriarcal de Joäo Procópio Correa da Silva.

Nery, R. V. (2008) Vozes da Cidade: Música no Espaço Público de Lisboa no Final do Antigo Regime, in Miguel Figueira de Faria, ed., Praças Reais: Passado, Presente e Futuro, 23-44

Neves, L. M. B. P. (2010). Guerra aos franceses: a política externa de Dom João VI e a ocupação de Caiena. Revista Navigator, 6(11), 70-82.

Pacheco, A. J. V. (2012). Hino para a Aclamação de D. João VI: edição e contextualização (com partitura inédita). OPUS, 18(1), 41-72.

Pereira, A. M. (1808). Evora, no seu abatimento, gloriosamente exaltada: Typ. Lacerdina.

Pereira, L. S. (2010). Aspectos da performance historicamente orientada do repertório setecentista para clarinete.

PT-ADEVR-PRQEVR-EVR12-003-0006_m0051.TIF

PT-ADEVR-PRQEVR-EVR12-003-0006_m0052.TIF

PT-ADEVR-PRQEVR-EVR12-003-0006_m0053.TIF

Shrock, D. (2009). Choral repertoire. Oxford University Press.

Vaz, F. A. L. (2012, October). A casa da sabedoria-uma leitura dos estatutos da Biblioteca Pública de Évora de 1811. In Anales de Documentación (Vol. 15, No. 2). Facultad de Comunicación y Documentación y Servicio de Publicaciones de la Universidad de Murcia. ISSN: 1697-7904. http:// dx.doi.org/10.6018/analesdoc.15.2.154091

Vieira, E. (1900). Diccionario biographico de musicos portuguezes: historia e bibliographia da musica em Portugal (Vol. 1 e 2). Typ. M. Moreira \& Pinheiro. 


\section{PATRINIÓNIO NISICAL NA CATEDRAL DE ANGRA NO SÉCULO XVII: TRÊS LIVROS DE POLIFONIA VOCAL SACRA E O SEU POSSÍVEL CONTEXTO}

Musical heritage in Angra Cathedral in the seventeenth century: three books of sacred vocal polyphony and their possible context

\section{Luís Henriques}

E-mail: luiscfhenriques@gmail.com

CESEM/Universidade de Évora 


\title{
Resumo
}

A Catedral de Angra foi, desde a sua fundação em 1534, um importante centro musical na ilha Terceira e no arquipélago dos Açores. Embora a sua atividade musical não seja conhecida em detalhe, várias referências documentais sugerem que esta seria pelo menos próxima das catedrais do continente português. Um dos testemunhos documentais é a existência na Catedral de três livros de coro impressos de polifonia vocal sacra de dois dos mais conhecidos compositores portugueses da primeira metade do século XVII: Duarte Lobo e Fr. Manuel Cardoso. O período em que estes livros foram impressos $(1605,1613$ e 1621) foi marcado por agitação na cidade de Angra durante a ocupação espanhola. Simultaneamente, a construção da nova Catedral durou quase um século, perturbando a sua atividade litúrgico-musical regular. Partindo dos três livros de polifonia existentes, o presente estudo analisa o património musical da Catedral durante a primeira metade do século XVII e a sua ralação com o seu contexto circundante.

Palavras-chave: Catedral de Angra; Património musical; Livros de polifonia; Paisagem sonora.

\begin{abstract}
The Cathedral of Angra was, since its foundation in 1534, an important musical centre in the island of Terceira and in the Azores archipelago. Although its musical activity is not known in detail, several documental references suggest that it was at least very close to the mainland Portuguese cathedrals. One of these documental testimonies is the existence in the Cathedral of three printed sacred vocal polyphony choirbooks by two of the most known Portuguese composers of the first half of the seventeenth century: Duarte Lobo and Fr. Manuel Cardoso. The period in which these books were printed $(1605,1613$ and 1621) was marked by unrest in the city of Angra during the Spanish occupation. Simultaneously, the construction of the new Cathedral lasted for almost a century, disrupting its regular liturgical-musical activity. Departing from the three existing polyphonic books, the present study analyses the Cathedral's musical heritage during the first half of the seventeenth century and the relation with its surrounding context.
\end{abstract}

Keywords: Angra Cathedral; Musical heritage; Polyphony books; Soundscape. 
A cidade de Angra foi um importante centro estratégico nas navegações dos portugueses entre os séculos XVI e XVIII, constituindo um ponto de paragem e abastecimento nas rotas atlânticas. Este estatuto, aliado à sua elevação a cidade e sede de diocese em 1534, consolidou a sua centralidade atlântica ao longo de quinhentos e seiscentos (Costa, 2008,132). Em termos históricos, Angra foi ainda entre o final do século XVI e meados de seiscentos, um dos palcos principais das disputas entre Portugal e Castela pela soberania portuguesa, sendo também um período rico em eventos que, direta ou indiretamente, tiveram consequências na sua paisagem sonora. Este período de crise, até à consolidação da Restauração nas ilhas, correspondeu ainda à construção da nova Catedral de Angra, obra que causou certamente um profundo impacto na dinâmica da cidade.

A segunda metade do século XVI e centúria seguinte foi marcada pelas iniciativas litúrgico-musicais emanadas do Concílio de Trento, constituindo a música um importante elemento da Contra-Reforma. No que concerne às reformas emanadas de Trento, estas refletiram-se na aceitação pelas igrejas portuguesas das normas litúrgicas unificadas, no âmbito litúrgico-musical pela imposição do Missal e Breviário romanos, editados durante pontificado de Pio V, constituindo a versão oficial dos textos destinados à celebração da Missa e do Ofício Divino respetivamente. Não tiveram, todavia, um impacto imediato, uma vez que nem o Concílio nem as várias comissões criadas posteriormente conseguiram produzir uma versão unificada do cantochão correspondente aos textos oficiais suficientemente forte para ser imposta ao mundo católico (Nery e Castro, 1992, p. 50). Por exemplo, na Capela Real de Lisboa, o Passionário em vigor nessa instituição da autoria de Jacob Fernandes Fermoso (impresso em 1543) foi substituído por um novo, da autoria do padre Manuel Cardoso (impresso em 1575), "conforme o missa da impressam de Plantino, \& ao breuiario que nouamente foram ordenados \& impressos, por decreto do sagrado Concilio Tridentino" e, em 1595, este foi, por sua vez, substituído por um outro da autoria de Fr. Estêvão de Cristo (Nery e Castro, 1992, p. 50-51). No entanto, a partir do final do século XVI parece existir uma dicotomia entre o repertório musical realizado na Capela Real e nas capelas palacianas e aquele realizado nas catedrais portuguesas. Por um lado, as capelas palacianas possuíam um repertório exclusivo, visando uma elite de ouvintes dotados de uma cultura e conhecimento musical sofisticado, demonstrando desse modo uma maior abertura a ideias estéticas mais diversificadas e complexas, assim tecnicamente mais exigentes. Por outro lado, o repertório das capelas catedralícias destinava-se a atrair um grande público e, por isso mesmo, era quase sempre de uma natureza mais austera e simples, assentando quase sempre num estilo de escrita imitativa a quatro vozes (Nery e Castro, 1992, p. 51). Este parece ser o caso da Catedral de Angra, reportando-se à presença nesta Catedral dos livros objeto de estudo do presente trabalho.

A distinção entre estes dois contextos musicais (palaciano e catedralício) torna-se importante referir, uma vez que uma grande percentagem da polifonia portuguesa impressa e escrita em manuscrito ao longo da primeira metade do século XVII 
corresponde ao corpus de repertório marcadamente mais conservador e, deste modo, destinado a um contexto catedralício transmitindo, por vezes, uma imagem parcial e redutora, da diversidade e riqueza da prática polifónica em Portugal (Nery e Castro, 1992, p. 51-52).

Em termos musicais, a criação da Diocese de Angra em 1534 iniciou uma fase de estabelecimento de certas estruturas e cargos de natureza musical na igreja de São Salvador que, de um momento para o outro, se viu como o principal estabelecimento eclesiástico da cidade. Começou com o aumento do salário do organista que aí servia, ordenado a 18 de outubro de 1540. A 27 de abril de 1553 foi ordenada a criação e adição de quatro moços do coro ao efetivo musical da igreja que nessa altura servia de Catedral e, a 3 de julho de 1561, mais dois moços, provenientes do colégio dos órfão, que servissem no coro, mas também no altar e onde a sua presença fosse requerida. Em 1567 é criado oficialmente o cargo de mestre de capela da Catedral que, para além das funções de direção musical da capela, tinha também a obrigação de ensinar cantochão e canto de órgão a quem quisesse aprender, assim como ensinar vinte moços pobres indicados pelo bispo (Henriques, 2012, p. 64). Resumidamente, esta foi a cronologia do estabelecimento progressivo dos cargos musicais na Catedral de Angra, pelo que, já nas últimas décadas do século XVI estava esta instituição guarnecida das estruturas-base que asseguravam o serviço litúrgico-musical. A partir de meados do século XVI, possuía um mestre de capela, responsável por um grupo de seis capelães-cantores e quatro moços do coro, assim como um organista, tendo também a incumbência de ensinar os dois estilos musicais vigentes à época: o cantochão, compreendendo a grande percentagem do repertório musical que era cantado na celebração dos ofícios diários no coro da Catedral, e o canto de órgão ou polifonia, o repertório que era utilizado como meio de solenizar determinadas festas do calendário litúrgico.

Paralelamente ao desenvolvimento da sua estrutura musical, também se desenvolveu a própria estrutura física do templo que servia de Catedral. Por se achar exígua a primitiva igreja de São Salvador, foi decidido construir um novo templo que servisse de Catedral, digno da diocese que então se havia criado. $\mathrm{O}$ lançamento da primeira pedra foi realizado a 18 de novembro de 1570, seguindo o cerimonial próprio. A comunidade saiu em procissão da igreja de São Salvador, que ficava no local onde se iria erigir o novo edifício, em direção ao local onde seria colocada a pedra fundacional. Neste cortejo tomou parte o Cabido da Catedral, a colegiada de Nossa Senhora da Conceição, o desembargador, o provedor da fazenda, armada e fortificações, o juiz, o senado, o procurador da cidade, outras figuras da administração da cidade e muito povo. Presidiu à cerimónia o deão Baltazar Gonçalves, tendo o mesmo colocado a pedra, estando presentes também os cónegos da Catedral (Mota, 2007, p. 28). A obra da Catedral teve como seu primeiro mestre Luís Gonçalves Cotta, a que é também atribuída a autoria da respetiva traça, constituindo um dos primeiros casos nas ilhas açorianas de um templo que contraria a tradicional orientação Nascente-Poente, condicionada por 
imposições urbanísticas (Laranjeira, 2008, p. 14). O longo período que demorou a construção da nova Catedral acompanhou os desenvolvimentos políticos do reino que se refletiram profundamente na dinâmica da ilha Terceira. Ainda em 1572 o rei D. Sebastião enviava a Angra um novo traçado para a nova Catedral. No entanto, as obras pararam no ano de 1583 por via das lutas da Sucessão, que se vinham agravando desde 1580, sendo os fundos encaminhados para a defesa e fortificação da ilha (Laranjeira, 2008, p. 15). As obras retomaram em 1590 por determinação de D. Filipe II, porém, a um ritmo certamente mais lento que anteriormente uma vez que em 1592 uma parte substancial dos fundos foi desviada para a grande fortaleza que se começou a erguer no Monte Brasil (Laranjeira, 2008, p. 16). Em 1608, Luís Mendes foi nomeado mestre das obras da Catedral. Em 1609 prepararam-se planos para a construção de um claustro anexo à Catedral o que veio a efetivar-se, sendo Baltazar Álvares o autor da respetiva traça (Leite, 2015, p. 44). Este espaço, como nas outras catedrais portuguesas (veja-se, por exemplo o caso da Catedral de Évora), transformava-se em local de ensino e do cultivo das artes e humanidades, sugerindo as iniciativas para a sua construção em Angra de um claustro haver necessidade da sua existência, nomeadamente também para a realização de certas procissões.

De acordo com o padre Manuel Luís Maldonado, obras de pedraria e alvenaria da Catedral terão terminado por volta do ano de 1618, porém afirma que "de seus inspetores não houve boa fama, pelo desperdício que se lhes notou na distribuição dos muitos fundos a ella applicados", uma vez que na obra até então haviam sido aplicados cento e dezasseis mil cento e trinta e oito cruzados. Já a 20 de dezembro de 1615, o Santíssimo Sacramento tinha sido colocado no novo templo (Lopes, 1965-66, p. 145). Esta referência sugere que por essa data já se realizava a celebração de serviços litúrgicos no altar ou outro espaço que servisse de tal no edifício que iria servir de nova Catedral o que, implicitamente, também incluiria a prática musical, pelo menos, do cantochão. A partir de 1618 continuou a Catedral recebendo os três mil cruzados do pastel até à Restauração, tendo sido gastos mais sessenta e seis mil cruzados nas obras até 1640 (Maldonado, 1990, p. 441). Após a Restauração, os três mil cruzados foram desviados para financiar a fortificação da costa da ilha, argumentando D. João IV que esta quantia era dada havia mais de sessenta anos e que nesse espaço tinha sido o dinheiro gasto em despesas supérfluas. No entanto, a 11 de março de 1644, o mesmo monarca revogava essa decisão, determinando que, tendo em consideração a Catedral tinha de se acabar e aperfeiçoar, fossem novamente dados os três mil cruzados anuais para a conclusão das obras (Laranjeira, 2008, p. 18).

Relativamente às obras no interior do novo templo, a capela-mor foi mandada dourar no tempo de D. João IV, assim como aprimorar a sacristia, com um custo de mais de sessenta e seis contos. O seu sucessor, D. Afonso VI acompanhou as obras e ofereceu vários paramentos para a Catedral, sendo estes benefícios continuados por D. Pedro II. Só a 16 de março de 1683 foi extinto o cargo de mestre de obras da Catedral (Laranjeira, 2008, p. 18). 
É importante referir a utilização continuada da primitiva igreja de São Salvador ao mesmo tempo que era envolvida pela obra da nova Catedral, o que não implicou o desmantelamento imediato da igreja paroquial. Uma das referências que corroboram esta afirmação foi a já mencionada cerimónia de lançamento da primeira pedra. Aí é referido que a procissão saiu da igreja de São Salvador, o que sugere que a dita igreja estaria ainda em plena atividade (Laranjeira, 2008, p. 15). Neste caso a existência do templo seria imprescindível ao desempenho regular das respetivas atividades litúrgico-musicais. Não será de todo irrelevante mencionar os transtornos causados por essa fase transitória entre os dois templos, que se arrastou por quase um século. A título de exemplo veja-se o caso da construção da capela-mor da Catedral de Évora nas primeiras décadas do século XVIII. Durante o período em durou a construção, muito próximo daquele da Catedral angrense, o coro-baixo da Catedral eborense foi transferido provisoriamente para o meio da nave central, o que terá alterado a dinâmica da atividade litúrgico-musical desse templo (Henriques, 2018, p. 88). Deste modo, embora com poucos detalhes sobre como se processou essa transição em Angra, é de supor que, com maior ou menor incidência, também a atividade litúrgicomusical do coro da Catedral de Angra também terá sido afetada.

Desconhece-se quaisquer detalhes arquitetónicos do interior da igreja paroquial de São Salvador. No que diz respeito à nova Catedral, o padre António Cordeiro traça uma descrição geral da mesma cerca de um século após a o termo das obras de pedraria e alvenaria. De acordo com este jesuíta, a Catedral estava dividida em três naves, com o "coro capitular em cima da entrada" (Cordeiro, 1717, p. 279). Possuía quatro capelas de cada parte, duas menos fundas e duas tão grandes "que podiao ser Capellas mores, entre as quaes na nave do meyo está o capitular coro de bayxo, \& logo se segue a Capella mor" (Cordeiro, 1717, p. 280). Cordeiro descreve a localização dos dois coros capitulares, onde diariamente os cónegos, beneficiados e capelães tinham a obrigação de celebrar os vários ofícios, que corresponde à respetiva localização dos mesmos ainda no início do século XX.

No coro-baixo da Catedral encontrava-se o cadeiral dos capitulares, como descrito pelo padre Jerónimo Emiliano de Andrade em 1843. Como se vê na iconografia existente do início do século XX, estaria a estante de coro ao centro do coro, ladeada pelo cadeiral. Tinha doze lugares a cada lado, para as dignidades e cónegos, sendo a primeira cadeira da capítula (rematada com as armas reais), e em baixo, os bancos destinados aos beneficiados e párocos, para os capelães e moços do coro (Costa, 1867, p. 94). Este tipo de descrição, embora sendo oitocentista, reflete em parte aquilo que seria a realidade da Catedral após a conclusão das obras do seu interior. Ainda em 1708 era arrematada a feitura do cadeiral para o coro-alto, que deixou de ser utilizado como tal em altura posterior (Costa, 1867, p. 93).

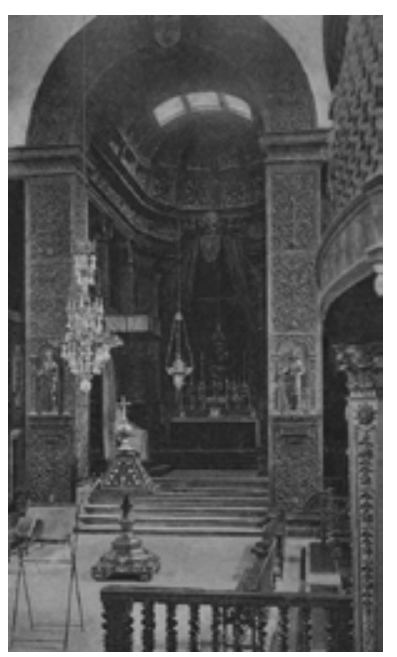

Coro baixo capitular da Catedral de Angra no início do século XX. Postal do início do século XX, de autor desconhecido. 
No respeitante aos cargos musicais da Catedral, que se desenvolveram simultaneamente com as obras da nova Catedral, conhece-se nas últimas décadas do século XVI a presença do padre Francisco Vaz como mestre de capela, acumulando também as funções de organista. Desconhece-se quanto tempo permaneceu nesses cargos, embora o seu falecimento tenha ocorrida em 1622 (Valença, 1990, p. 141-142). Em 1595 foi realizado contrato para a compra de novos órgãos ${ }^{1}$ para a Catedral ao clérigo de missa Nicolau de Resende, a fim de substituir os "de realejo" aí existentes (Lopes, 1965-66, p. 144). Certamente com intenção de guarnecer o novo tempo que ora se construía, a substituição dos órgãos de realejo existentes por outros, mais atualizados aos padrões da época, seria um melhoramento considerável na atividade musical da Catedral. Em termos de organistas da Catedral, desconhecem-se nomes entre Francisco Vaz e o padre João Baptista Camelo, que surge como tangedor dos órgãos no ano de 1688 (Mota, 2007, p. 36).

No que concerne aos mestres de capela que desempenharam atividade ao longo da primeira metade do século XVII, as referências, embora vagas, identificam a presença de três indivíduos a ocupar esse cargo. Deste modo, conhece-se a presença do já referido Francisco Vaz, de Gonçalo Nunes, nomeado mestre de capela no ano de 1622 por morte do antecessor Francisco Vaz, ${ }^{2}$ e Francisco de Almeida, sub-chantre da Catedral, nomeado para o mesmo cargo em 1640, por morte do antecessor, Gonçalo Nunes. ${ }^{3}$ Estes parecem ter sido as três figuras centrais nos destinos musicais da Catedral de Angra. Porém, para além destas notas biográficas, não se conhecem mais detalhes acerca da sua atividade. Também são escassos os detalhes respeitantes ao património musical (composições musicais) polifónico que seria realizado na Catedral ao longo do século XVII à exceção dos exemplos que serão referidos posteriormente.

No fundo musical do Arquivo Capitular da Sé de Angra foram encontrados em 2012 três livros de coro impressos de polifonia vocal sacra, contendo obras de dois destacados compositores portugueses da primeira metade do século XVII: Duarte Lobo e Fr. Manuel Cardoso (Henriques, 2012, p. 64). Trata-se do Cantica Beatae Mariae Virginis, vulgo Magnificat de Duarte Lobo, obra impressa em por João Moreto na Oficina Plantiniana de Antuérpia no ano de 1605. Compreende dezasseis versões polifónicas do cântico Magnificat distribuídas pelos oito tons, uma correspondendo aos versos ímpares e outra para os versos pares (Borges, 1986, p. 120-121). O mesmo ocorre com o segundo volume, também com dezasseis

1 Aqui, o termo "órgãos" é utilizado no plural, embora se desconheça se se tratava apenas de um ou dois instrumentos. O termo é por vezes utilizado no plural para designar apenas um instrumentos.

Arquivo Nacional da Torre do Tombo, Chancelaria Antiga da Ordem de Cristo, Livro 34, f. 262v. 
versões polifónicas do Magnificat, nos oito tons com uma versão para os versos ímpares e outra para os versos pares. O volume foi impresso em Lisboa na oficina de Pedro Craesbeeck no ano de 1613. Em 1621 foi impresso por Baltazar Moreto na Oficina Plantiniana de Antuérpia o terceiro volume de polifonia hoje existente no Arquivo Capitular da Catedral, o primeiro Liber Missarum de Duarte Lobo. O livro compreende as antífonas para a aspersão Asperges me e Vidi aquam, oito missas entre quatro e oito vozes, entre as quais cinco missas-paródia, três delas sobre motetes de Francisco Guerrero e duas sobre motetes Giovanni Pierluigi da Palestrina. O volume encerra com dois motetes fúnebres, Pater peccavi para cinco vozes e Audivi vocem de caelo para seis vozes (Henriques, 2013, p. 34).

Desconhece-se a data em que estes três volumes vieram parar à Catedral de Angra, nem quais os indivíduos envolvidos na sua aquisição, uma vez que nenhum dos livros possui quaisquer marcas de posse ou anotações que o sugiram. Os arquivos da Catedral também não forneceram ainda qualquer informação sobre os ditos volumes (Henriques, 2012, p. 64-65). Em todo o caso, com base nas datas de impressão, assim como alguns casos de aquisição dos mesmos por parte de catedrais do continente português, poder-se-á avançar algumas hipóteses em termos de datas. Ao mesmo tempo, o que se conhece em termos da circulação de música no espaço Ibérico durante o século XVII poderá também contribuir para um possível cenário sobre a sua vinda para a Angra.

O ano de 1605, data da impressão do livro de Magnificat de Lobo, e 1621, data da impressão do Liber Missarum do mesmo compositor, situam-se como balizas temporais do objeto em análise no presente estudo. Para estes dois exemplos, encontra-se também alguma correspondência entre Lobo e a Oficina Plantiniana relativa ao desenvolvimento do respetivo processo de impressão dos desses dois volumes.

De acordo com uma carta, datada de 24 de julho de 1600, sabe-se que do livro de 1605 imprimiram-se trezentos exemplares, que custaram quatrocentos e vinte ducados (Borges, 1986, p. 121). No Grand livre Au Soleil 1600-1608 da Oficina Plantiniana encontra-se uma entrada referente a 18 de janeiro de 1605. Nesse dia, foram os trezentos exemplares metidos em três arcas (cem em cada), sendo as mesmas entregues a António Fallero que sairia de Calais cabendo-lhe a entrega a Lobo (Borges, 1986, p. 126). Partindo desta referência, percebe-se que as arcas terão saído de Calais no início de 1605 e, certamente, terão chegado a Lisboa no mesmo ano. A partir desta cidade terá sido, então, feita a distribuição dos ditos exemplares pelas outras instituições, incluindo aquelas onde se encontram atualmente. A título de exemplo, sabe-se que no inventário da sacristia da Catedral nova de Coimbra, datado de 1635, surge já tanto o livro de Magnificat, como o primeiro livro de missas de Lobo, o último deles impresso dez anos antes. De Fr. Manuel Cardoso surge apenas um livro de missas, certamente o livro que

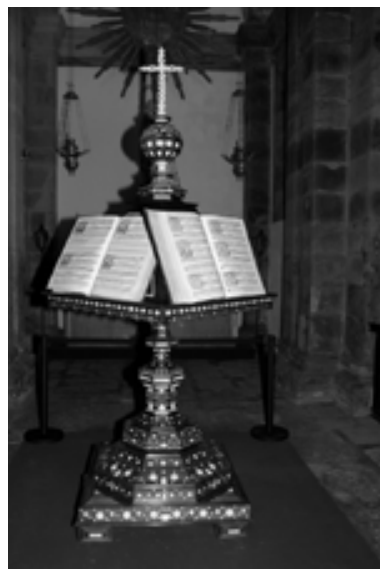

Liber Missarum e Cantica Beatae Mariae Virginis de Duarte Lobo na estante de coro proveniente do antigo Convento de São Francisco de Angra. Foto Mike Maciel. 
imprimiu em 1625, não existindo menção ao livro de Magnificat (Alegria, 1985, p. 52). ${ }^{4}$ Esta referência leva a analisar o tempo que demorava cada instituição a receber os respetivos livros de polifonia. Por um lado, sabe-se, como se viu anteriormente, que Lobo terá recebido o livro de Magnificat no ano em que foi impresso, 1605, e que a Catedral de Coimbra tinha-o no seu inventário em 1635, assim como o livro de missas impresso em 1621. Já mais tardio é o inventário realizado na Catedral de Elvas no ano de $1678 .^{5}$ Neste documento encontram-se listados os dois livros de Duarte Lobo, assim como o de Fr. Manuel Cardoso, junto com outros volumes de Filipe de Magalhães, Cristóbal de Morales, Tomás Luis de Victoria e Philippe Rogier. Curiosamente, a Diocese de Elvas foi criada apenas trinta e seis anos após a de Angra, ainda em pleno século XVI, o que a coloca muito próxima da diocese açoriana em termos da sua organização litúrgicomusical. De facto, a presença dos livros de coro no inventário de 1678 pressupõe que já estivessem em uso na Catedral no período anterior à sua realização. Isto leva a crer que, num espaço de meio século, as obras de Lobo e Cardoso estariam já difundidas pelas catedrais e igrejas portuguesas, tendo também chegado a Angra durante esse espaço de tempo, talvez mais prolongado que Coimbra, por via da viagem marítima que consumiria bastante mais tempo. Por estas contas, supõe-se que os livros tivessem chegado a Angra muito possivelmente na década de 1630 ou no período imediato à Restauração.

Uma outra referência reveste-se de alguma importância porque identifica uma aquisição do livro de missas de 1621. Trata-se de uma nota capitular da sessão do Cabido da Catedral de Coimbra realizada a 4 de dezembro de 1623. Esta nota, registada pelo secretário do Cabido João de Vilas Boas, foi aberta na sessão capitular uma carta de Duarte Lobo, beneficiado na Catedral de Lisboa, tendose entregado também um livro de canto de órgão que este havia enviado junto. Assentou-se que se mandasse averiguar o valor do livro a fim de "se lhe mandar pagar o q' parecesse" (Alegria, 1984, p. 42). José Augusto Alegria aponta esta nota capitular como um exemplo da forma como os compositores da época distribuíam as obras sem indicarem o custo, "sujeitando-se à maior ou menor generosidade das Corporações que as recebiam" (Alegria, 1984, p. 44). Desconhece-se se caso semelhante terá ocorrido na Catedral de Angra, não se estabelecendo qualquer tipo de comparação entre os fundos disponíveis na Catedral conimbricense para a aquisição de repertório musical com os fundos da Catedral angrense, com maiores constrangimentos, como se vê pelos sucessivos aumentos das dignidades e cónegos ao longo do século XVI, visto as quantias que recebiam serem livro de Magnificat de Lobo, perfaziam três obras onde estavam presentes versões polifónicas deste cântico o que, leva a crer, não justificava a aquisição do livro de Cardoso. 
manifestamente insuficientes ao seu mantimento e desempenho das respetivas atividades (Mota, 2007, p. 18).

Ressalta um outro detalhe de alguma importância no que respeita ao exemplo conimbricense acima referido. Trata-se de quem adquiriu estes livros de coro polifónicos. A referência documental aponta para o cenário de decisão sobre o pagamento do livro de missas de Lobo pertencente ao Cabido da Catedral, que o decidiria em sessão capitular. Isto significa que era o Cabido da Catedral, pelo menos nesse caso de Coimbra, quem tomava a última decisão sobre o repertório a adquirir para o serviço musical da Catedral e, por conseguinte, era também esta corporação que custeava a respetiva aquisição. Certamente haveria participação de outras figuras, nomeadamente do plano musical da instituição, que teriam uma palavra avaliadora sobre o repertório a adquirir. Estas figuras seriam possivelmente o chantre, ou sub-chantre, o mestre de capela e ainda o organista ou outro cantor ou mestre de música com mais antiguidade na instituição. Este poderá ter sido o caso no que diz respeito aos livros da Catedral de Angra.

Em todo o caso, o período que circunda a impressão destes três livros de coro correspondeu a um período de pouca estabilidade no governo da Diocese de Angra. A centúria de seiscentos abriu com a nomeação de D. Jerónimo Teixeira Cabral para Bispo de Angra, onde permaneceu até 1612, ano em que passou à Diocese de Miranda. Durante o seu bispado foi construído o claustro da Catedral (Mota, 2007, p. 125-126). Foi também um bispo bastante ativo em termos de proibições de comportamentos, nomeadamente dos foliões bailarem nas capelas-mores das igrejas em dias de coroações do Espírito Santo. Sucedeu-lhe D. Agostinho Ribeiro, confirmado por alvará de 14 de julho de 1614, permaneceu como governador do Bispado até ao seu falecimento a 12 de julho de 1621. Foi conhecido pelo estilo eloquente da sua oratória e elevado poder em mover as massas de fiéis nos templos onde pregava (Mota, 2007, p.126-127). Seguiram-se alguns bispados curta duração, nomeadamente o de D. Pedro da Costa Leal, que tomou posse da diocese a 24 de agosto de 1623, cuja relação com a governança da cidade não foi propriamente muito pacífica. D. João Pimental de Abreu, que permaneceu na diocese de 1626 a 1632, também não granjeou grande popularidade na cidade, sendo criticado pelo seu demasiado apego aos bens materiais. Pelo contrário, D. Fr. António da Ressurreição, Bispo de Angra entre 1635 e 1637, ficou conhecido pelo seu desapego aos bens materiais, sendo-lhe colados adjetivos como modesto, sem vaidades humanas e de "reformados costumes" (Mota, 2007, p. 127-129). A partir deste bispo ocorreu um longo período de trinta e quatro anos de sede vacante até à confirmação de D. Fr. Lourenço de Castro a 18 de maio de 1671. Este longo hiato em termos da governação do bispado terá sido certamente influenciado pelos acontecimentos em torno da Restauração, nomeadamente a guerra com Espanha que apenas teve desfecho em 1668. Após a Restauração, refere o padre Manuel Luís Maldonado, esteve o bispado vago por se haver aclamado D. João IV "e não quererem os Summos pontífices aceitar a nomeação dos Bispos que o dito Senhor Rey lhes aprezentaua" (Maldonado, 1990, p. 135). 
Durante os anos de sede vacante governou o bispado como vigário geral e provisor o licenciado Gaspar Cardoso Cardim. Este chegou a Angra, já rendida a fortaleza de São Filipe, a 23 de março de 1642 na comitiva militar do general António de Saldanha (Maldonado, 1990, p. 243). Deste modo, torna-se difícil perceber a sucessão nos cargos de governação do Bispado de Angra até à década de 1670, uma vez que, não só as crónicas não são pouco claras em termos dos indivíduos que se foram sucedendo, como também o próprio percurso governativo dos mesmos não permite vislumbrar quaisquer tipos de investimentos onde se pudesse incluir a aquisição dos livros de polifonia.

Folheando os três volumes, sobretudo o livro de missas, consegue-se extrair algumas leituras a partir do seu manuseamento. No caso do livro de Magnificat de Lobo, os fólios iniciais revelam sinais de terem sido muito manuseados, neste caso o canto inferior direito encontra-se amarelecido, faltando também o frontispício, dedicatória e licenças. Os sinais de maior uso concentram-se nas duas versões do cântico para o primeiro tom, faltando também os primeiros fólios da versão polifónica para os versos ímpares. O mesmo acontece com o livro de Magnificat de Cardoso, ao qual falta o frontispício e os primeiros fólios do índice e licenças. No entanto, contrariamente ao livro de Lobo, o de Cardoso não aparenta marcas de uso extensivo encontrando-se os fólios em bom estado de conservação. O Liber Missarum de 1621 é o volume onde se conseguem identificar mais extensivamente marcas da sua utilização. Tal como os outros dois volumes, também ao Liber Missarum falta o frontispício, sobrando apenas a dedicatória e licenças de impressão. Estas concentram-se sobretudo em três zonas principais do livro, em torno de três obras. A primeira destas obras é a antífona para a aspersão Asperges me, que seria cantada ao longo do ano litúrgico, exceto durante o período Pascal onde se deveria cantar a antífona Vidi aquam. As marcas de uso desta composição musical inicial são notórias, uma vez que seria a antífona cantada em todas as missas que exigissem a solenização com polifonia. As outras duas obras são a Missa De Beata Virgine, para quatro vozes, e a Missa pro Defunctis, para oito vozes. No caso da primeira obra, aquela com marcas mais profundas de um uso intensivo, há que referir o impulso que o culto da Virgem Maria teve a partir do Concílio de Trento, nomeadamente através da religiosidade popular (Enes, 1991, p. 261). O culto de Nossa Senhora do Rosário, apesar das suas raízes medievais, apresenta-se no período pós-tridentino como um culto novo, que terá uma forte expressão no arquipélago dos Açores, à qual a nova Catedral não será estranha incluindo uma capela dessa devoção da já existente confraria (Mota, 2007, p. 82-83). A missa em questão de Lobo estava destinada às festas comuns marianas ao longo do ano litúrgico podendo, deste modo, ser cantada nas festas marianas celebradas na Catedral.

O caso da Missa pro Defunctis justifica-se como uma das obras musicais destinadas a um momento específico da liturgia e que ser repetiria com grande frequência na atividade litúrgico-musical da Catedral. A versão para oito vozes de Lobo constituía um elemento de solenização de ofícios fúnebres mais importantes 
na cidade. Desde os aniversários, celebrados regularmente na Catedral no seguimento de instituições e legados de figuras importantes da nobreza e do clero local, também os ofícios celebrados após o falecimento de figuras de destaque na sociedade da urbe terceirense seriam solenizados com polifonia, intercalada com o usual ofício de cantochão. Um dos exemplos no respeitante à chegada de notícias a Angra da capital do reino foi aquela respeitante ao falecimento de el-rei D. João IV. Este monarca havia falecido a 6 de novembro de 1646 tendo a notícia chegado à cidade de Angra no início de março do ano seguinte. De acordo com o padre Manuel Luís Maldonado, fizeram-se as "demonstrações possiueis em ordem, aos lutos, e funerais das Exequias" (Maldonado, 1990, p. 358). Na Catedral montou-se uma eça no centro do coro capitular defronte da capelamor. As exéquias foram solenizadas "a todo o maior custo com tal pompa que não faltaram na asistencia" os ministros da Catedral, todos os párocos da cidade, assim como o clero extravagante e comunidades religiosas. Cantou-se "o officio a dous choros com toda a perfeição, porquanto para isso forão chamados todos os sogeitos mais cientes, e dextros na Muzica" (Maldonado, 1990, p. 360). Embora não havendo mais referências acerca de qual o ofício cantado, a presença da Missa pro Defunctis para oito vozes no Liber Missarum de Lobo, aliada à referência policoral na descrição de Maldonado, sugerem a possibilidade de ter sido interpretada a missa de Lobo, tendo a capela sido reforçada em termos de efetivos para essa cerimónia.

Em jeito de conclusão, pode-se adiantar que o desenvolvimento dos cargos musicais na Catedral de Angra, gradualmente estabelecidos após a criação da diocese em 1534, terão incentivado a aquisição de repertório polifónico para uso na Catedral. Os três livros, objeto do presente estudo, constituem até ao momento os exemplares mais antigos de repertório musical conhecido no arquipélago dos Açores. A sua associação à Catedral de Angra sugere que esta instituição estivesse em posição económica de adquirir os respetivos volumes, que à época não seriam baratos, sendo a mesma muito provavelmente realizada por intermédio do Cabido, à partida, a corporação com recursos e poder para realizar essa ação. Estes livros, escritos em polifonia imitativa ao jeito do que se fazia no século XVI, estavam destinados a um publico mais vasto e seriam utilizados pelos seis capelães-cantores e quatro moços de coro que provavelmente estariam sob a direção dos mestres de capela enumerados anteriormente. Deste modo os três livros presentes neste estudo revelam-se como importantes peças do património musical açoriano mas, ao mesmo tempo, importantes elementos no entendimento da atividade musical na Catedral de Angra ao longo do século XVII. 


\section{BIBLIOGRAFIA}

Alegria, J. A. (1985). O Ensino e prática da Música nas Sés de Portugal (Da Reconquista aos fins do século XVI). Lisboa, Instituto de Cultura e Língua Portuguesa.

Alegria, J. A. (1984). Polifonistas Portugueses. Duarte Lobo. Filipe de Magalhães. Francisco Martins. Lisboa: Instituto de Cultura e Língua Portuguesa.

Andrade, J. E.de (1891). Topographia ou Descripção física, politica, civil, ecclesiastica, e histórica da Ilha Terceira dos Açôres. Parte Primeira anotada pelo vigário José Alves da Silva. Angra do Heroísmo: Livraria Religiosa - Editora.

Borges, A. (1986). Duarte Lobo (156?-1646): Studien zum Leben und Schaffen des portugiesischen Komponisten. Regensburg: Gustav Bosse Verlag.

Costa. F. (1867). Angra do Heroismo Ilha Terceira (Açores) (Os seus títulos, edifícios e estabelecimentos públicos). Angra do Heroísmo: Typ. do Governo Civil.

Costa, S. (2008). Açores: Nove Ilhas, Uma História. Berkeley, Institute of Governmental Studies Press/University of California.

Enes, M. F. (1991). Reforma Tridentina e Religião Vivida (Os Açores na Época Moderna). Ponta Delgada: Signo.

Henriques, L. (2018). "A nova capela-mor setecentista da Catedral de Évora: Uma abordagem ao seu impacto na atividade musical de Pedro Vaz Rego e Ignácio António Celestino". Arte y Patrimonio, n. 3, pp. 77-92. 
Henriques, L. (2013). "Polifonia na Sé de Angra: O Liber Missarum de Duarte Lobo". Cadernos de Musicologia - Glosas, n. 9, pp. 32-36.

Henriques, L. (2012). "Polifonia na Sé de Angra? Três Impressos de Sacra Portuguesa Seiscentista”. Glosas, n. 6, pp. 64-65.

Laranjeira, M. (2008). São Salvador de Angra: uma catedral sebástica. Angra do Heroísmo: Instituto Açoriano de Cultura.

Leite, A. R. (2015). "A Sé de Angra, Cabeça do Bispado dos Açores". Norba, Revista de Arte, vol. XXXV, pp. 27-46.

Lopes, F. (1965-66). "Da Praça às Covas: Memórias de uma Velha Rua". Boletim do Instituto Histórico da Ilha Terceira, vol. 23-24, pp. 9-

Maldonado, M. L. (1990). Fenix Angrence. Volume II. Angra do Heroísmo: Instituto Histórico da Ilha Terceira.

Mota, V. (2007). Santa Sé do Salvador: Igreja Catedral dos Açores. Angra do Heroísmo: Sé de Angra.

Nery, R. V. e Castro, P. F. de (1992). História da Música (Sínteses de Cultura Portuguesa). Lisboa: Imprensa Nacional - Casa da Moeda.

Valença, M. (1990). A Arte Organística em Portugal (c. 1326 - 1750). Braga: [Editorial Franciscana]. 
A INOVACIOO

ARQUITETÓNICA NOS

ATELIERS DE LISBOA

E OEIRAS. ENTRE 1867

A 1912

The architectural innovation in Lisbon and Oeiras studios between 1867 and 1912

\section{António Cota Fevereiro}

E-mail: antoniofranciscocotafevereiro@gmail.com

ARTIS - Instituto de História da Arte, Faculdade de Letras da Universidade de Lisboa 


\section{Resumo}

No final do século XIX e início do XX foram construídos em Lisboa e Oeiras ateliers para trabalho, mas também para exposição e convívio. Estes foram construídos de acordo com novos conceitos espaciais apoiados no desenvolvimento das técnicas construtivas, realçados pelo controlo da luz natural. Inicialmente o ecletismo definiu arquitetonicamente estes espaços, contudo à medida que o século chegou ao fim, os projectistas portugueses conciliaram de forma inovadora referências da sua cultura com as novas correntes estéticas internacionais. Estes ateliers enriquecem a arquitetura portuguesa deste período, além de trazerem novas reflexões em torno de quem lá trabalhou.

Palavras-chave: Atelier; Luz; Espaço; Decoração; Volume.

\section{Abstract}

In the late nineteenth and early twentieth centuries, several working studios were built in Lisbon and Oeiras, but also to show and entertain. These were created after new spatial concepts based on the development of building technics, enhanced by natural light. Initially eclecticism architecturally defined these spaces, but as the century drew to its end Portuguese designers innovatively conciliated references of their own culture with new international aesthetic movements. These studios enrich the Portuguese architecture during this period, which also gave way to new reflections around who worked there.

Keywords: Studio; Light; Space; Decoration; Volume. 


\section{Introdução}

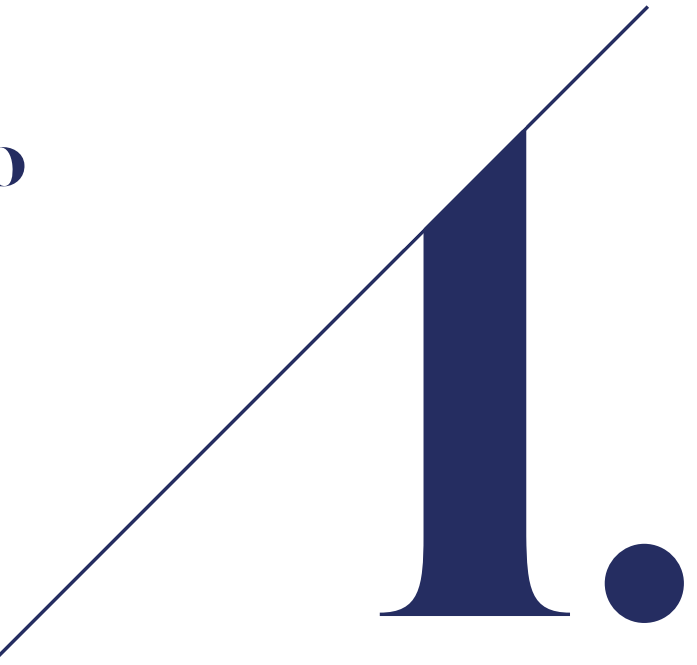

No século XIX o conforto no interior da habitação e a utilização de novos métodos construtivos despoletaram a exploração de espaços especificamente desenhados para um determinado fim. A relação entre diferentes zonas no interior dos edifícios tornaramse mais fluidas e complementares (Ramos, 2010: 51-73). Neste contexto, o atelier surge como um espaço integrado no interior doméstico ou autónomo. A incidência de luz no seu interior foi sabiamente controlada pelo dimensionamento dos vãos e sistemas artificiais, originando diversos tipos de ateliers especificamente desenhados para uma determinada função. Nuns o proprietário dedicava-se a aperfeiçoar uma determinada vertente artística; noutros, constituía o espaço de trabalho imprescindível a uma profissão liberal. O atelier funcionava como local de trabalho e também de estudo, de estar e de exposição. O gosto oitocentista pelas artes, pelas exposições e pela mundanidade gerou espaços complementares como galerias e salas, onde se exibiam as últimas criações. Nestes o desenho arquitetónico e decoração era inspirado no ecletismo (reinterpretação de épocas históricas passadas), o qual foi contestado a partir de 1890 por artistas e que deu origem ao movimento Arte Nova em França. Gradualmente esta corrente estética foi também fonte de inspiração para a criação artística na Bélgica, Alemanha e Áustria, entre outros países europeus (Sembach, 1996: 8-31). A mesma influência chegou pouco tempo depois a Portugal (Fevereiro, 2017a: 228-237) e coincidiu com a questão da casa à portugueza, impulsionada pelo arquiteto Raul Lino (1879-1974) e outros intelectuais em finais do século XIX (Ribeiro, 1994: 75-103). Estas duas tendências foram magistralmente reinterpretadas por projetistas portugueses em determinados projetos arquitetónicos, entre eles os dos ateliers. 


\section{Atclicrs cm Lisboa c Ociras}

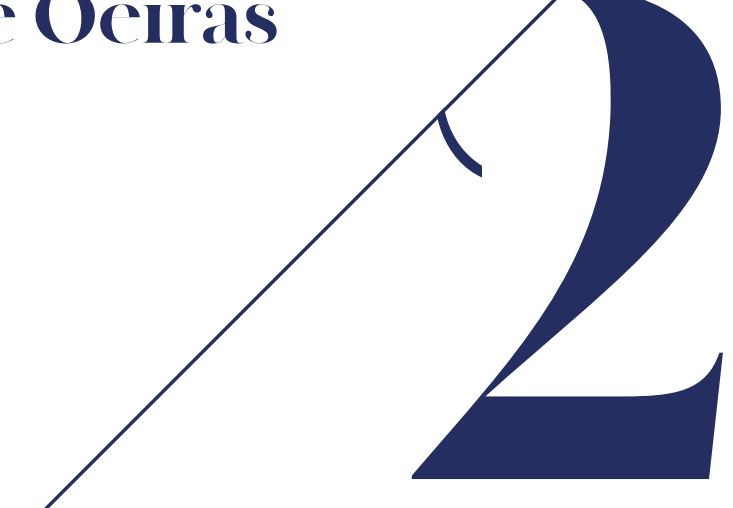

No presente estudo foram localizados ateliers em Lisboa e Oeiras erigidos entre a segunda metade do século XIX e o início da Primeira Grande Guerra, os quais refletem no seu desenho arquitetónico a passagem do electismo oitocentista para a aurora do novo século.

Os ateliers foram ordenados de acordo com o seu uso e cronologicamente, de forma a facilitar um melhor entendimento das diferentes apropriações espaciais.

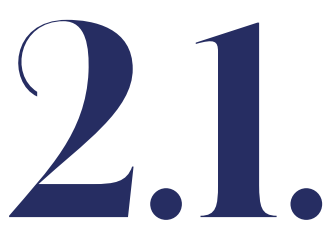

\section{Escultura}

\section{Atelier Duquesa de Palmela}

D. Maria Luísa de Sousa Holstein (1841-1909), $3^{\text {a }}$ duquesa de Palmela, mandou construir um atelier para escultura nos jardins do seu palácio, em 1867, na rua da Escola Politécnica em Lisboa e teve como professor o famoso escultor francês Célestin Anatole Calmels (1822-1906) (Saldanha, 2006: 103). Nos jardins também houve um pequeno estúdio para modelação e pintura em cerâmica, fundando

1 Queremos agradecer à Dr. ${ }^{a}$ Cristina Neiva Correia o repto para escrever este artigo. 
para esse fim a Fábrica de Cerâmica do Ratinho em 1872 com D. Josefa Pimentel de Menezes Brito do Rio (1840-1892), Condessa de Ficalho (Queirós, 1907: 328).

O atelier de escultura é uma construção inspirada em elementos arquitetónicos de madeira rústicos da europa central, embora empregues de forma sofisticada, em voga naquela época. No seu interior, pelo que podemos observar nas fotografias existentes em arquivo $^{2}$ (O'Neill, 1909: 136), no eixo central estava um janelão com parapeito elevado e prolongamento até à sanca do tecto. De um dos lados havia um fogão em pedra ladeado por um par de candeeiros Carcel, assentes em candelabros ao gosto greco-romano (Caron e Van Weyenbergh, 1968) (Fevereiro, 2019: 207), com uma moldura a simular troncos rústicos com espelho e decorado com jarras ao gosto oriental. Também havia um piano, um estrado central para as esculturas com escadote, vários pedestais com esculturas e vasos com tampa em porcelana oriental, cadeiras neo-renascentistas, cadeiras de espaldar setecentistas, uma arca neo-gótica, uma secretária tipo Boule, um órgão (referido pelo Conde de Sabugosa) e armários com livros e papelada. Parte do mobiliário também apresentava um acabamento rusticado característico das décadas de 1860 e 1870 (Griffo, 1998: 548), em consonância com a arquitetura exterior. Nas paredes estavam telas, peanhas, esculturas e outros objetos decorativos que completavam a atmosfera artística deste espaço. Num dos vãos, o pano de porta tinha o brasão da Casa de Palmela.

A atmosfera instrospectiva era assim conseguida pelo desenho arquitetónico do seu interior, funcionando igualmente como espaço de estar para os convidados da Duquesa de Palmela (Sabugosa, 1921: 206-211).

\section{Casa/Atelier Costa Mota}

Na Ribeira de Algés foi construída uma moradia para o escultor António Augusto da Costa Mota (1862-1930), cujo projecto deu entrada no dia 9 de outubro de 1906 (A.M.O., 1906: fl. 1) na Câmara Municipal de Oeiras. O arquiteto foi Álvaro Augusto Machado (1874-1844), mas no dia 10 de outubro do mesmo ano foi publicado um projecto do mesmo autor, na revista A Construcção Moderna, para "[...] atelier e casa de habitação de um distincto esculptor, que, modesto como são em geral os artistas de valor, quis tambem que se guarde o incognito, pelo menos até estar feita a obra." (Collares, 1906, 66). Os dois projectos diferem substancialmente entre si.

2 O interior foi fotografado por Francesco Rocchini nos finais do século XIX, cujos negativos pertencem ao Arquivo Municipal de Lisboa - Arquivo Fotográfico e as cotas são as seguintes: ROC000062, ROC000063, ROC000064 ROC000065 e ROC000066. Também há uma fotografia da Duquesa e da autoria do fotógrafo Paulo Guedes (1886-1947), pertencente à mesma instituição, com a cota PAG000753. 
O lote para a sua construção é em declive e no projecto publicado o arquiteto partiu da conjugação de dois volumes, adaptando-os à topografia do terreno. O volume da moradia seria no topo, ocupando a extremidade norte do lote, com cave. O volume do atelier seria perpendicular ao da moradia, ao mesmo nível que a cave e aproveitando-a para arrecadações, com a fachada sobre o arruamento. De um lado seria o portão principal, com jardim e escadaria exterior para a moradia, e do outro o de serviço.

O volume do atelier teria um vestíbulo principal com o escritório em frente, iluminado por um pequeno vão a sul. O atelier propriamente dito seria à direita, com um janelão que se prolongaria para a cobertura a norte e uma porta exterior a sul. A oficina à esquerda, com outro janelão a norte e outra porta a sul, e as arrecadações na cave da moradia.

Desenhos técnicos do edifício na publicação A Construcção Moderna e que são: alçado principal; corte longitudinal; alçado lateral sul; alçado tardoz; alçado lateral norte e planta do primeiro andar (Collares, 1906a:

65).

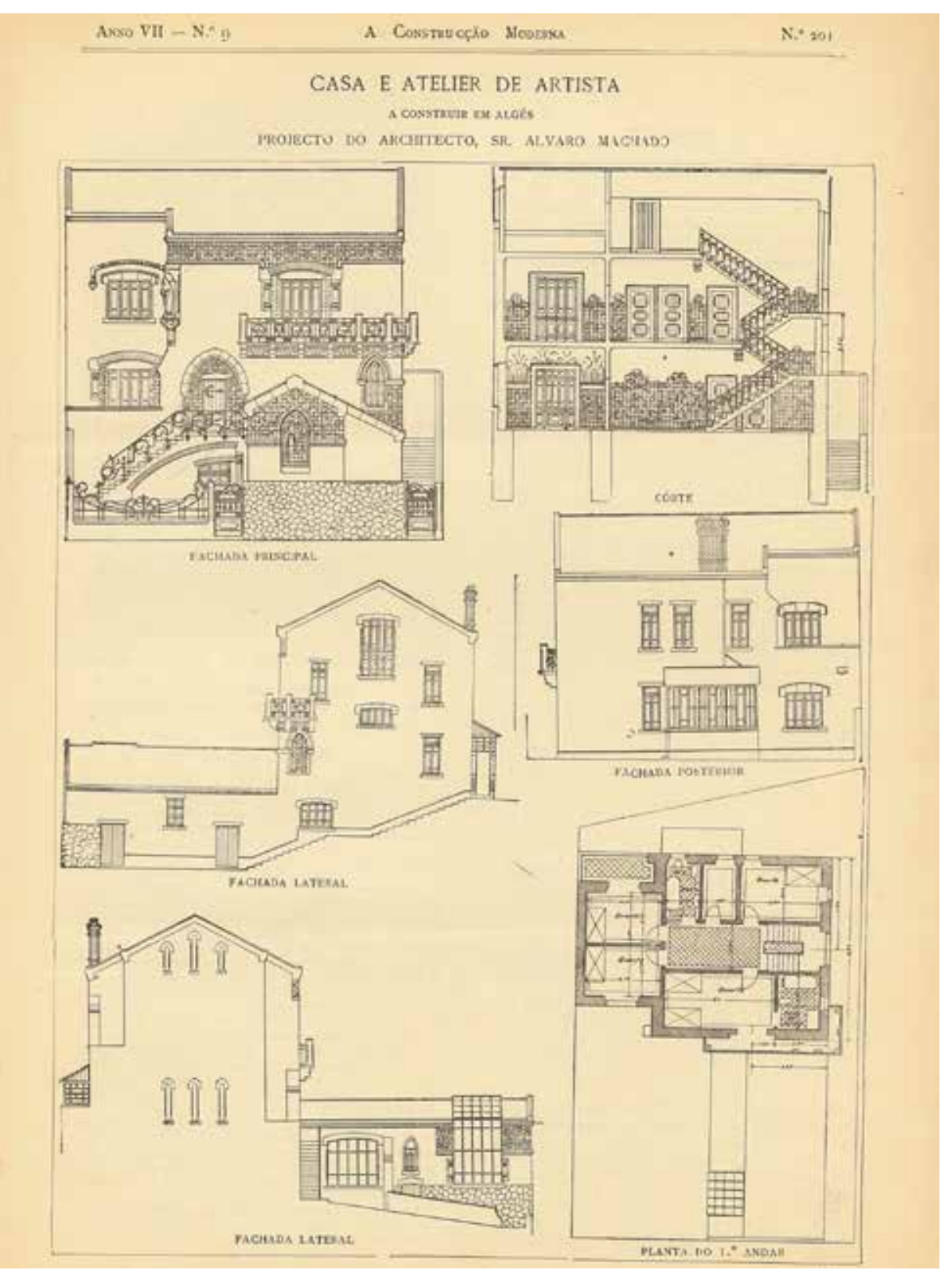


Álvaro Machado conjuga dois volumes, intersectando-os, e separando a habitação do espaço de trabalho. A assimetria das fachadas, o dimensionamento dos vãos de acordo com o espaço interior e o controlo da incidência de luz no seu interior foram ponderados de forma exímia.

Na fachada principal do atelier foi proposta a inclusão de um painel em azulejo, numa moldura com arco ogival ao gosto gótico. As restantes fachadas e vãos seriam realçados com outros painéis em azulejo, com motivos padronizados desenhados pelo arquiteto. As ferragens e outras decorações seriam ao gosto Arte Nova e no cunhal da fachada poente/norte foi desenhado um nicho para uma escultura.

Neste projeto o arquiteto envereda pelo desenvolvimento da volumetria que evidencia um espaço interior, aproximando-se assim da arquitetura contemporânea belga e alemã (Borsi e Wieser, 1996). Para realçar a volumetria adotou as faixas azulejares, prática em voga desde a década de 90 do século XIX (Fevereiro, 2017a: 229-232), valorizando esta arte portuguesa. O seu uso também foi proposto em lambris para o vestíbulo, escadaria e sala de jantar da habitação.

O projecto entregue na Câmara de Oeiras manteve só o volume da moradia, que era decorada na cimalha com azulejaria padronizada Arte Nova.

Este edifício foi demolido na segunda metade do século XX (Fevereiro, 2011: 431-435).

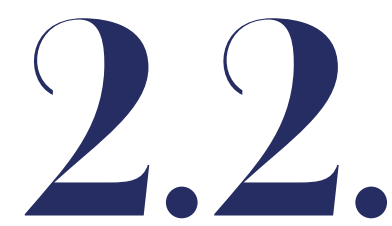

\section{Fotografia}

\section{Atelier Francesco Rocchini}

O atelier do fotógrafo italiano Francesco Rocchini (c.1821-1893) ${ }^{3}$ era na cobertura de um edifício de gaveto, na Rua São Pedro de Alcântara e Travessa da Água Flôr

3 Francesco Rocchini nasceu por volta de 1821 na freguesia de São Miguel da cidade de Monteleone, na altura pertencente ao Reino de Nápoles, e hoje Vibo Valentia. Era filho de Saverio Rocchini e de Francesca Paola. Veio para Lisboa, tornou-se fotógrafo e casou no dia 11 de outubro de 1851 na freguesia da Lapa de Lisboa com a portuguesa Hipólita Carolina Nunes (viúva de Hilário José da Costa), onde eram moradores. O fotógrafo morreu já viúvo na Travessa de Água Flor n. ${ }^{\circ} 1$ no dia 4 de dezembro de 1893, na freguesia da Encarnação da mesma cidade, fez testamento e não deixou filhos. 
em Lisboa, onde se instalou por volta de 1865. O atelier destacava-se no exterior por superfícies em vidro e por um volme, mas nas últimas obras de beneficiação desapareceram quaisquer traços da sua existência. Tanto pior quanto no volume de obra n. ${ }^{\circ}$ 9519, consultado no Arquivo Intermédio da Câmara Municipal de Lisboa, não constam quaisquer projectos para o atelier. Esta conjugação infeliz impede-nos, até que apareçam testemunhos claros do seu interior, de saber como fixava as imagens um dos mais importantes fotógrafos de Lisboa. ${ }^{4}$

\section{Galeria photographica Damião da Graça}

No Largo do Regedor, num edifício pertencente à Câmara Municipal de Lisboa, o retratista Damião da Graça ${ }^{5}$ (c.1831-?) apresentou em 1882 um projeto para uma galeria photographica (A.M.L., 1882: fl.1). ${ }^{6}$ Esta construção, em estrutura metálica e vidro, assentava sobre a cobertura em madeira de um edifício de gaveto. A distribuição interna era a seguinte: escada interna na extremidade sul, uma sala a nascente e duas divisões a norte. Não sabemos para que finalidade servia esta estrutura, mas como o nome indica, seria com toda a probabilidade um espaço para realizar e expor fotografias. O uso intensivo do vidro pelas fachadas e cobertura conferiam uma certa desmaterialização a estes espaços, inundados pela luz, possivelmente controlada por meios artificiais.

Damião da Graça foi proprietário da Photographia Nacional na Praça da Alegria n. ${ }^{\circ}$ 106, reproduziu e comercializou fotografias tiradas pelo famoso fotógrafo francês Jean Laurent (1816-1886) à Família Real Portuguesa quando esteve, em 1869, em Lisboa (Araújo, 2011: 92). Também participou na Exposiçao Industrial Portugueza de 1888 conjuntamente com outros fotógrafos, entre eles os reputados Carlos Relvas ${ }^{7}$ (1838-1894) e João Francisco Camacho (1833-1898) (Algumas informações, 1888: 68).

O edifício foi demolido e hoje corresponde ao Regimento de Sapadores de Bombeiro - $1^{\text {a }}$ Companhia - Quartel do Rossio, instalado em edifício próprio.

4 Sobre a fotografia no século XIX ver a obra desenvolvida pelo arquiteto Nuno Borges de Araújo (Araújo, 2017a: 55-88) (Araújo, 2017b: 4-31) (Araújo, 2011: 87-108).

5

Era natural de Tomar, onde foi exposto na roda da Santa Casa da Misericórdia e batizado na Real Igreja da Colegiada de São João Batista. Casou no dia de 25 de novembro de 1863 na freguesia de Santos-o-Velho de Lisboa com Mariana Augusta, de 22 anos, natural da freguesia de São Lourenço de Azeitão, filha de João Rolim e de Antónia Maria José.

6

O pedido para a sua construção deu entrada no dia 12 de julho de 1882 na Câmara Municipal de Lisboa.

7

A sua Casa-Estúdio na Golegã é um dos mais completos e originais espaços oitocentistas realizados para a fotografia, onde a arquitura e a espacialidade estão em perfeita consonância com a função. 


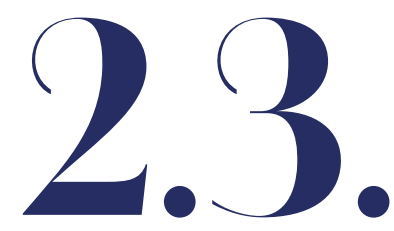

\section{Arquitetura}

\section{Casa/Atelier Nicola Bigaglia}

Numa malha urbana já consolidada entre a Rua das Taipas e a Rua de Santo António da Glória existiu um edifício de habitação, com jardim, ampliado em $1883 .{ }^{8}$ Esta propriedade em 1904 pertencia ao arquiteto italiano Nicola Bigaglia (18411908) e apresentou um projecto para a construção de duas moradias com oficina, ateliers e respectivos depósitos na Câmara Municipal de Lisboa (A.M.L., 1904b: fl.1). O projecto não seguiu em frente e foi substituído por outro semelhante e construído, mas sem os ateliers, em 1906 por Bigaglia (A.M.L., 1906: fl.1). ${ }^{9}$

O projecto de 1904 é ordenado da seguinte maneira:

\footnotetext{
- Dois portões exteriores para jardim, que por sua vez comunicariam com as portas da zona de serviço das habitações e os vestíbulos dos ateliers nas extremidades do lote;

- Duas portas para cada habitação na Rua das Taipas;

- Um portão comum e central com escadaria para a oficina na cave.
}

Cada vestíbulo teria uma galeria e escadaria descendente para o atelier, contornando assim o desnível entre a rua e o terreno, de formato quase rectangular, construído em cimento e com duplo pé direito. O cunhal norte seria uma fachada em ângulo com um janelão na vertical e toilette. Cada atelier teria uma oficina comum e depósitos independentes na cave do edifício, com a referida escadaria para o portão central. A escala do atelier, o seu dimensionamento, a iluminação controlada e a escadaria com galeria seria o ponto de união entre o jardim e a cave do edifício.

8

O proprietário era Guilherme Pires da Silva e apresentou, na Câmara Municipal de Lisboa, um pedido para ampliação do edifício no dia 11 de maio de 1883. No dia de 3 de novembro de 1884 pediu prorrogação por mais 6 meses para a sua finalização. O procurador foi provavelmente o arquiteto José António Gaspar (1842-1909).

9

Os pedidos entregues na Câmara Municipal de Lisboa foram os seguintes: construção do barracão para as obras 25 de fevereiro de 1904; construção do muro de vedação e suporte 15 de março de 1904; construção do edifício 15 de novembro de 1904; aprovação 9 de janeiro de 1905; prorrogação por mais 12 meses 11 de janeiro de 1906; modificações 28 de maio de 1906; numeração de portas 4 de setembro de 1906; projeto de alterações na cave e construção de um quarto para criado 26 de setembro de 1907. 
Na versão construída foram preteridos, embora se mantivessem as oficinas e depósitos. O desenho arquitectónico do edifício tem influências da arquitecura clássica italiana e a fachada principal tinha uma aparente simetria. O embasamento é em pedra emparelhada irregular. O reboco do rés-do-chão e primeiro andar simulava aparelho de pedra regular. O segundo andar tinha pinturas a fresco ao gosto Arte Nova, com linhas sinuosas entrelaçadas de vinhas e cachos de uva (Fevereiro, 2017a: 237). As ombreiras, as vergas e outros detalhes arquitetónicos também foram estilizados ao gosto Arte Nova. No cunhal da fachada sul para poente havia uma estátua de um anjo com coroa, mas nas obras de ampliação do edifício desapareceu. Na fachada lateral sul foi construída uma varanda coberta em madeira, com balaustrada e painéis perfurados com padrão estilizado. O desenho sofisticado das ripas remetia para a influência árabe das adufas, proporcionando privacidade ao interior da habitação.

Além de arquiteto e construtor civil Nicola Bigaglia ${ }^{10}$ também desenhava mobiliário, decoração interior e peças decorativas nas suas oficinas, alguns claramente estilizados ao gosto Arte Nova.

O edifício ardeu parcialmente, foi reconstruído em 1911 e pertencia ao Doutor Gama Pinto (1853-1945). No ano de 1965 foi ampliado para dar lugar a um hospital e foi recentemente alvo de obras. ${ }^{11}$

\section{Atelier Frederico Augusto Ribeiro}

Frederico Augusto Ribeiro (1853-?) foi entalhador e marceneiro, activo na cidade de Lisboa. Começou como operário e gradualmente tornou-se numa referência, tendo sido solicitado por altas individualidades e pela Família Real, nomeadamente para realizar o Gabinete do rei D. Carlos I (1863-1908), no Palácio das Necessidades, e a Sala de Jantar na Cidade de Cascais. Era também construtor civil e erigiu vários edifícios de projectistas, além de projectos de sua autoria (Fevereiro, 2012: 256-258).

O seu atelier era na Rua D. Estefânia em Lisboa e era forrado a madeira com vãos nas três paredes. Alguns destes tinham vitrais e coavam de forma controlada a luz no interior do espaço. A iluminação artificial era assegurada por pedestais com figuras

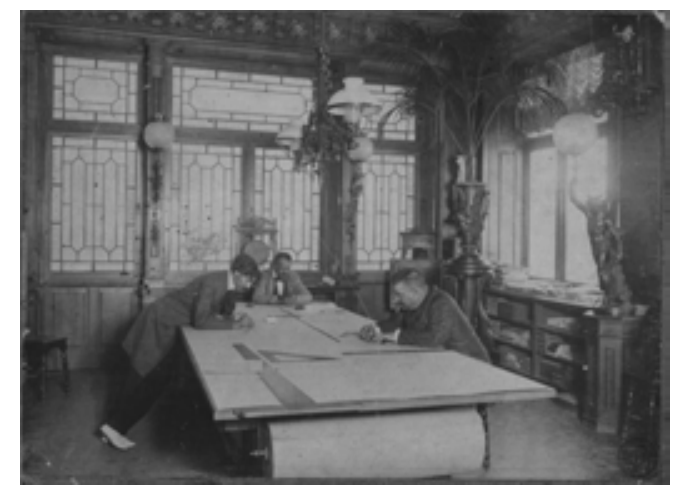

Vista do Atelier de Frederico Augusto Ribeiro, que poderá ser o que está do lado direito ou no topo do estirador. O arquiteto Norte Júnior

10

Era o construtor n. ${ }^{\circ} 91$ inscrito na Câmara Municipal de Lisboa.

11

O projeto de reconstrução deu entrada, na Câmara Municipal de Lisboa, no dia 23 de maio de 1911 e o construtor civil responsável foi Guilherme Francisco Baracho (construtor inscrito segundo o n. ${ }^{\circ} 94$ na Câmara Municipal de Lisboa), pela firma Vieillard \& Touzet. 
está do lado esquerdo com polainas brancas. A mesma fotografia e outra do ângulo oposto foram publicadas em 1902 na Brasil-Portugal

(Carvalheira, 1902: 682-683). Fotografia das Officinas Photographicas Praça dos Restauradores n. ${ }^{\circ} 38$ Lisboa, então pertencente ao fotógrafo Arnaldo Fonseca. Fotografia gentilmente cedida pela Senhora Dona Tânia Azeredo Perdigão, bisneta do arquiteto Norte Júnior.

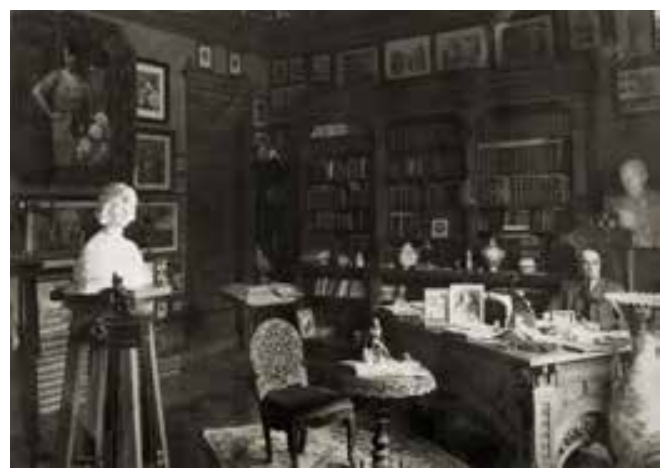

O gabinete do arquiteto Norte Júnior, onde o próprio está sentado do lado direito. Fotografia de autor desconhecido e anterior a 1962. Fotografia gentilmente cedida pela Senhora Dona Tânia Azeredo Perdigão, bisneta do arquiteto Norte Júnior. humanas que sustentavam na mão bicos de gás com globos e do teto pendiam lustres para gás, de dois braços, com abat-jours de vidro. Outros pedestais suportavam vasos com palmeiras e havia prateleiras com livros, tubos de desenhos, secretária, estirador, estante rotativa para livros e telas nas paredes. Este original espaço de trabalho de gosto eclético tinha um certo ambiente elegante, mas concentrado para o trabalho, onde a arte estava presente na decoração.

O edifício que albergava o atelier foi demolido no século XX. ${ }^{12}$

\section{Atelier Norte Júnior}

O atelier do arquiteto Manuel Joaquim Norte Júnior (1878-1962) foi construído em 1910 (A.M.L., 1910, fl.1) num lote triangular, rodeado por edifícios já existentes, na Praça Ilha do Faial. ${ }^{13}$

A porta principal, em ferro e vidro, comunicava com um vestíbulo de entrada, do qual se partia para um gabinete e um corredor. $\mathrm{O}$ gabinete era iluminado por um janelão, com vitral e peitoril em ferro. Este espaço comunicava internamente com outro quarto virado para as traseiras. O corredor ao fundo levava à escadaria, à porta para o quarto das traseiras, à entrada para o logradouro e à instalação sanitária.

A escadaria levava ao piso superior e no patamar encontrava-se a passagem para o atelier e a instalação sanitária. O atelier era iluminado com eficácia por uma grande claraboia de esteira e por sete janelas, dispostas horizontalmente e com floreiras no exterior, viradas a poente com vista para o jardim público. Temos assim uma eficiente separação, por pisos e espaços, do público para o local de trabalho. A escadaria e as instalações sanitárias foram estrategicamente colocadas na extremidade do lote, num dos vértices do triângulo, para que o gabinete e o atelier usufruíssem de maior área e de vãos para a fachada principal.
12 Queremos agradecer ao arquiteto Nuno Borges de Araújo a ajuda na identificação do autor da fotografia do Atelier de Frederico Augusto Ribeiro. O construtor civil responsável foi António Dias Monteiro (construtor inscrito segundo o n. ${ }^{\circ} 195$ na Câmara Municipal de Lisboa). O pedido para a sua construção deu entrada no dia 6 de junho de 1910. 
No interior o mobiliário foi desenhado por Norte Júnior e havia pinturas decorativas do pintor José Malhoa, conforme nos relata os descendentes do arquiteto.

A fachada principal arquitetonicamente tinha elementos arquitetónicos recorrentes na obra de Norte Júnior, como colunas, frontão quebrado e pilares. Estes eram realçados pelos vãos e vitrais inspirados na Arte Nova e na casa à portugueza. A cimalha da fachada principal era decorada com um friso em azulejo e terminava num beirado.

O edifício foi demolido em 1978.

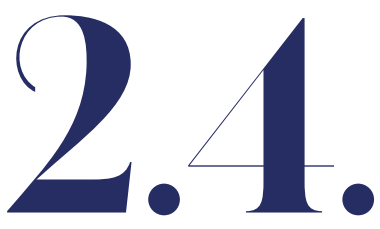

\section{Pintura}

\section{Casa/Atelier José Malhoa}

No ano de 1904 o pintor José Vital Branco Malhoa (1855-1933) encomendou ao arquiteto Norte Júnior um projeto de casa/atelier (A.M.L., 1904a: fl.1) ${ }^{14}$ e que ficou concluído em 1905, tendo sido galardoado nesse ano com o Prémio Valmor (C.M.L., 2004: 43) (Fevereiro, 2011: 647-654) (Marvile, 1909: 357-362). Foi construído no interior de um lote de gaveto com jardim, muros em pedra e gradeamentos em ferro ao gosto Arte Nova.

O edifício é a união de quatro volumes ordenados da seguinte maneira:

\footnotetext{
- Volume lateral com a escadaria;

- Volume central, no rés-do-chão a habitação e no primeiro andar o atelier;

- Volume lateral, no rés-do-chão a habitação e no primeiro andar a sala
}

14 Os restantes intervenientes foram Frederico Augusto Ribeiro (construtor inscrito segundo o n. ${ }^{\circ} 12$ na Câmara Municipal de Lisboa), Vicente Joaquim Esteves (serralharias), António Augusto da Costa Mota (peças escultóricas decorativas nas fachadas), José Vital Branco Malhoa (desenhos para pinturas decorativas exteriores), António Ramalho (desenhos para pinturas decorativas exteriores), João Eloy Ferreira do Amaral (execução das pinturas decorativas exteriores) e José António Jorge Pinto (azulejos baseados nas pinturas exteriores e possivelmente datados de 1914). Os pedidos entregues nos serviços camarários foram os seguintes: construção 15 de março de 1904; aproveitamento da cave para arrecadações 15 de março de 1904; alterações 24 de outubro de 1904; alteraçõe 9 de julho de 1914. 
de exposição;

- Volume lateral na fachada tardoz com a zona da cozinha e a sala de jantar no rés-do-chão.

O atelier é o espaço que mais se evidencia no exterior e tem na fachada principal um janelão envidraçado e uma varanda virados a norte. No interior tem duplo pé direito e uma galeria percorrível com escadaria, camuflando desta forma um corredor interno que comunicava com uma instalação sanitária. No tempo do pintor tinha vários cavaletes com telas, mesas, um calorífero, cadeiras e outros adereços para compor cenários. Nas fotografias sobreviventes são visíveis por cima das mesas pincéis, frascos e outros objectos essenciais à pintura. Nos corrimãos da galeria estavam pendurados panejamentos, também suspensos nas paredes, e na galeria superior havia prateleiras com livros e outros objectos. Este era um espaço de trabalho e de estudo que contrastava com o requinte da sala de exposição separados por um cortinado. Esta sala tinha sofás, telas e candeeiro de suspensão para gás.

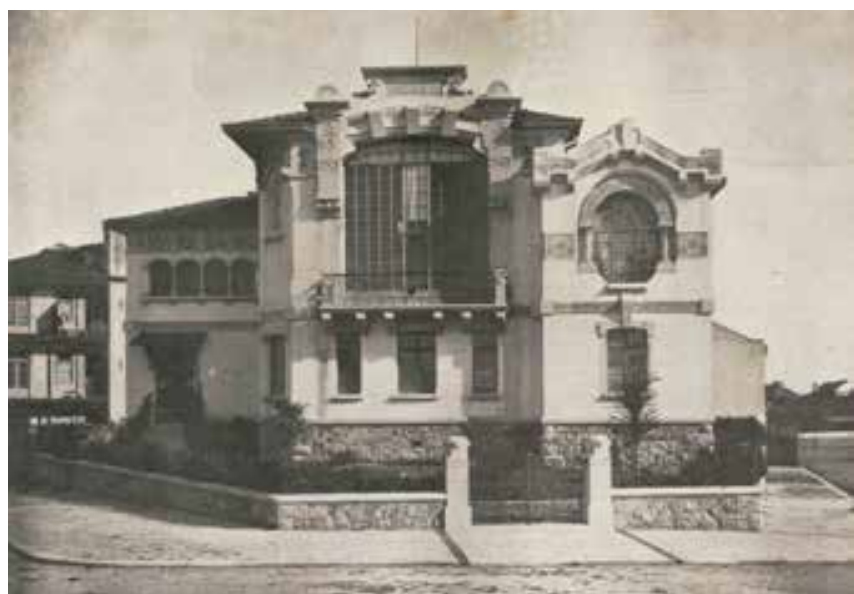

Fachada principal da casa/atelier Malhoa (Achilles, 1909: Intercalar III).

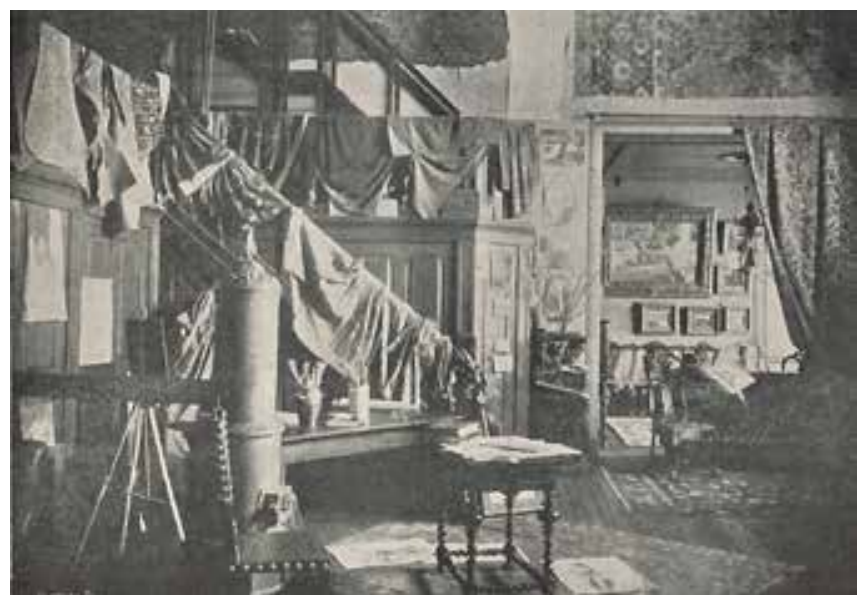

Vista do atelier, o início da escada para a galeria e a sala de exposição (Achilles, 1909: 7)

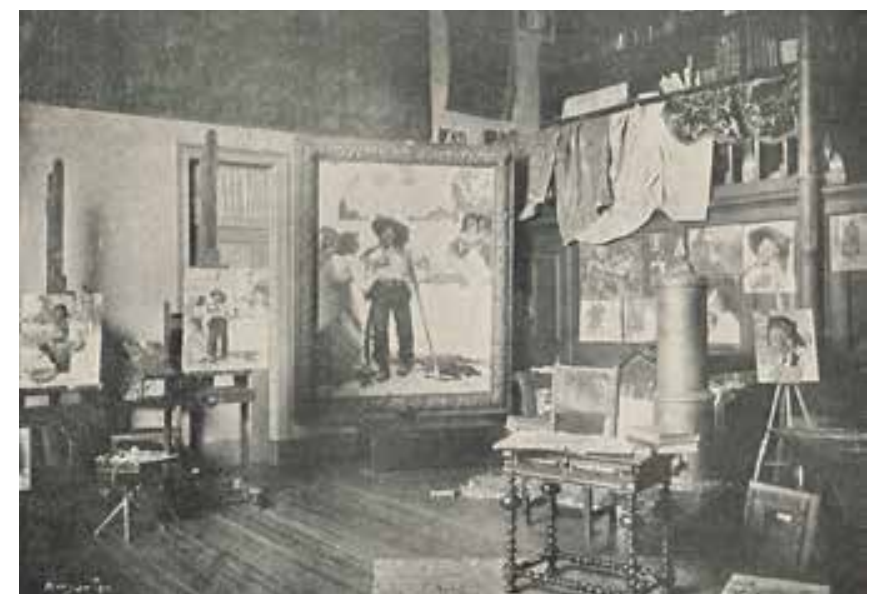

Vista do atelier com a porta e galeria superior (Achilles, 1909: 5).

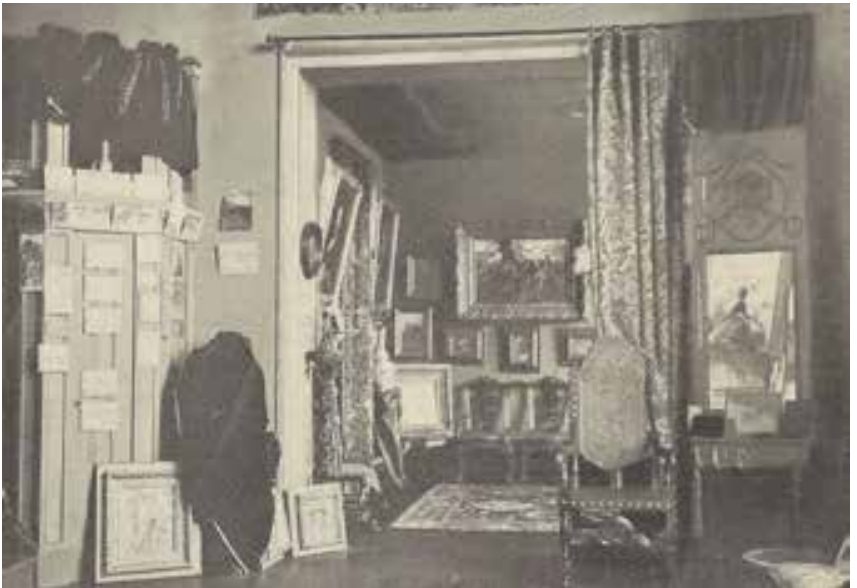

A sala de exposição (O pintor, 1906: 337). Imagem digitalizada a partir de um original que pertence à coleção do autor. 
No exterior os volumes criam ritmo e contraste de luz/sombra, pelo avanço e recuo de fachadas. O dimensionamento dos vãos, de acordo com as funções do espaço interior, contribuem para a assimetria das fachadas exteriores.

O edifício é nos dias de hoje a Casa-Museu Dr. Anastácio Gonçalves.

\section{Casa/Atelier João Vaz}

Nicola Bigaglia no mesmo ano que projectou a sua residência fez um projecto de casa/atelier para o pintor João José Vaz (1859-1931) (A.M.O., 1905: fl. 1) (Collares, 1912: 37-40). O edifício foi construído em 1905 no gaveto da Rua Joseph Bleck e D.

Francisco de Almeida ${ }^{15}$ no Alto do Dafundo. Ocupava a extremidade poente do lote, onde era a entrada principal na Rua D. Francisco de Almeida, e a fachada principal estava virada a sul, com vista para a foz do rio Tejo. Este projeto foi especificamente elaborado para o pintor que durante a sua carreira teve como tema preferido as paisagens marinhas.

O rés-do-chão tinha a sala de jantar com bow window, a sala de estar e a saleta viradas a sul. No primeiro andar situavam-se os quartos de cama, tendo um deles uma varanda exterior, no seguimento da bow window da sala de jantar, decorada com azulejos. Por cima da porta janela foi colocado um grande painel em azulejo, num plano recuado em relação à fachada, com os caracteres Gratia Plena e motivos estilizados, baseado nos desenhos que o arquiteto fez no alçado. Por cima deste painel existiam grinaldas de flores em azulejo recortado (Fevereiro, 2016: 66). Noutro quarto a janela era no cunhal da fachada nascente/sul, com coluna, painéis em azulejo no parapeito e uma peanha em pedra.

No segundo piso era o atelier, que ocupava metade da área do edifício, com uma trapeira sobre o telhado do primeiro andar, duas janelas na fachada norte e duas portas janelas com varanda na fachada poente. A fachada sul não tinha quaisquer vãos e desta forma controlava-se a intensidade excessiva de luz solar no seu interior, necessária à pintura e para não cansar as vistas. A varanda era em madeira com um desenho simples e sofisticado, remetendo para o vocabulário da casa à portugueza, com uma cobertura em madeira e telha.

Esta moradia tinha um desenho arquitectónico simples e os beirados realçavam as coberturas e as vergas de determinados vãos. A assimetria das fachadas, de

15

O pedido para a sua construção deu entrada, no dia 2 de abril de 1905, na Câmara Municipal de Oeiras e o construtor civil responsável foi Joaquim Craveiro Lopes, construtor n. ${ }^{\circ} 145$ inscrito na Câmara Municipal de Lisboa. O lote é formado pela Rua D. Francisco de Almeida a sul contornando para a Rua Joseph Bleck a norte. O edifício de apartamentos construído posteriormente tem a fachada com pastilhas amarelas e faixas em azul. 
acordo com os vãos e os espaços interiores, e o desenvolvimento das coberturas foram explorados inovadoramente. Neste projeto Bigaglia mesclou de forma original influências da arquitetura italiana com a portuguesa.

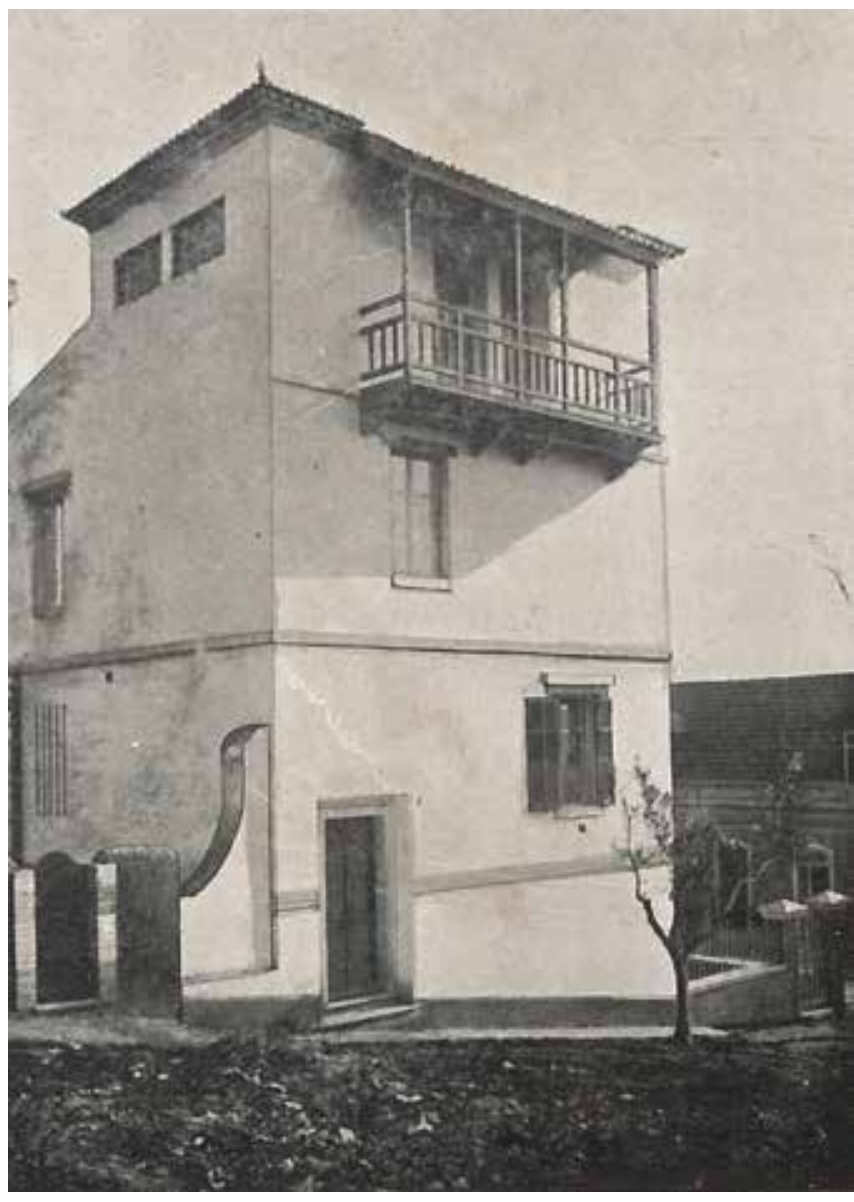

Fachada poente da casa/atelier João Vaz (Manaças, 1912: 39).

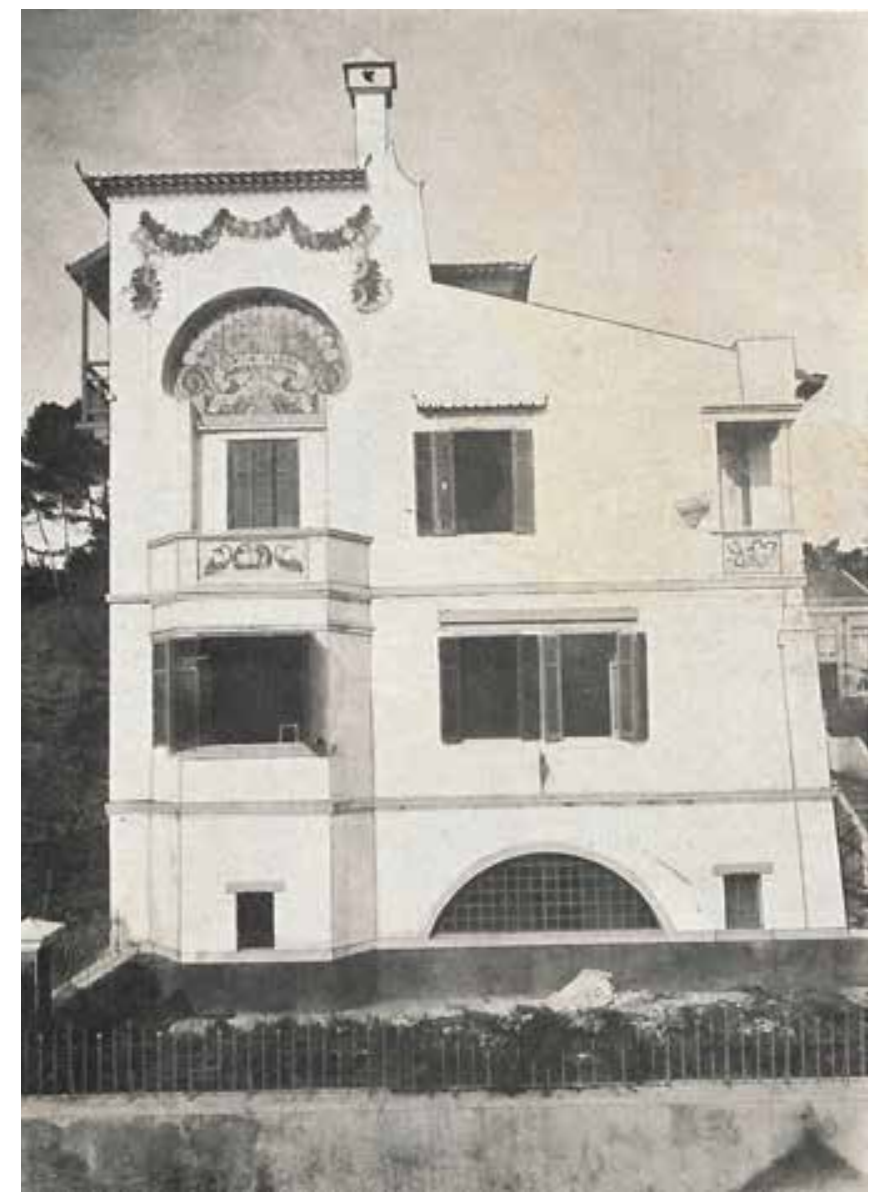

Fachada sul da casa/atelier João Vaz (Manaças, 1912: Intercalar XIX).

O edifício foi demolido na segunda metade do século XX.

\section{Atelier Constantino Fernandes}

No gaveto da Avenida Duque de Loulé e Rua do Andaluz foi construído um atelier para um pintor, cuja "[...] modestia de um novel mas já distincto artista, não nos permitte o nome do illustre proprietario do atelier que agora publicamos, e de cujo projecto é auctor o distinto architecto, a nosso illustre amigo, sr. Lacerda Marques, que já tem evidenciado o seu talento n`outras obras." (Collares, 1906, 58)

O pintor era Constantino Álvaro Sobral Fernandes (1878-1920) e encomendou o projeto ao arquiteto Tertuliano Marques (1882-1942). 
Num lote de formato triangular o arquiteto explorou a hierarquia e o equilíbrio de proporção entre três volumes. O central e de união estava a meio do lote, tinha um pátio exterior com jardim e o portão principal na Avenida Duque de Loulé. No seu interior havia uma instalação sanitária, uma arrecadação e um corredor com degraus ascendentes para as portas dos dois volumes laterais. O volume virado a norte era o gabinete de espera, com um janelão para a avenida e uma janela para um pátio exterior com jardim que rematava o gaveto. O volume principal era o do atelier propriamente dito, era o de maior dimensão e recebia luz de: uma pequena janela lateral à porta de entrada; um janelão na fachada principal virado a nascente; uma janela na fachada tardoz para a Rua do Andaluz; uma superfície envidraçada entre as duas paredes exteriores virada a norte e que se prolongava pela empena do telhado. Desta forma havia uma boa incidência de luz natural no seu interior, controlada por cortinas ou outros meios artificiais consoante a intensidade luminosa que se pretendia. Nas fotografias existentes podemos constatar a existência no interior do atelier de cadeiras, credência, relógio de caixa alta e outros objectos decorativos para compor cenários. Tinha um pequeno estrado com três degraus, cavaletes, armários com livros e todos os objectos necessários à pintura. Nas paredes exibiam-se telas, objectos decorativos, estatuetas e algumas prateleiras. Numa banca de trabalho estava um telescópio construído pelo pintor (Branco, 1920: 19-24).

A disposição dos volumes e o desenho arquitectónico evidenciava a sua função no exterior, destacando-se dos edifícios circundantes. Os muros e os pequenos jardins ajudavam a ter uma certa clausura e contacto com a Natureza neste singular e introspectivo atelier.

O atelier foi demolido em meados do século XX (Fevereiro, 2011: 431-435). ${ }^{16}$

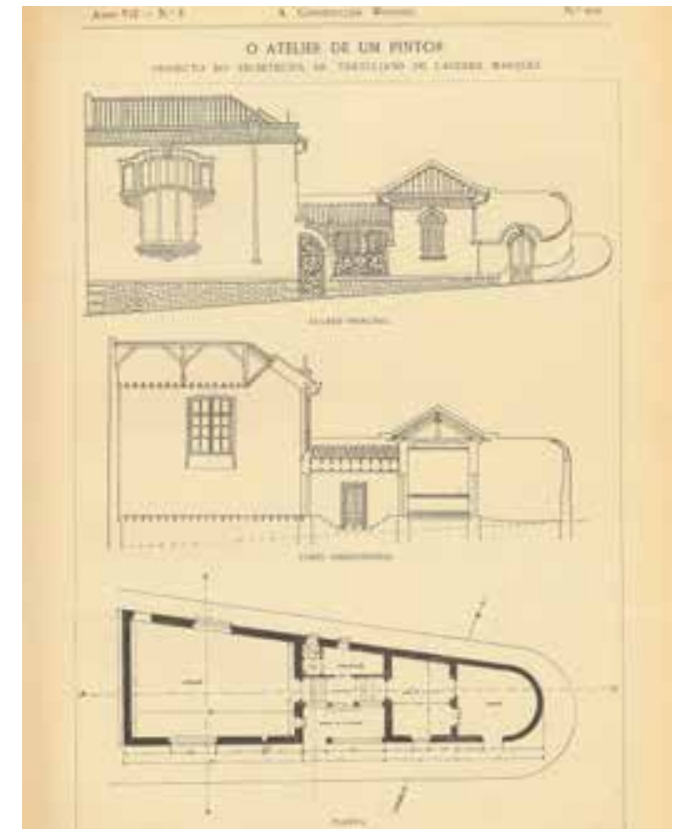

Alçado principal, corte longitudinal e planta do atelier (Collares, 1906b: 57)

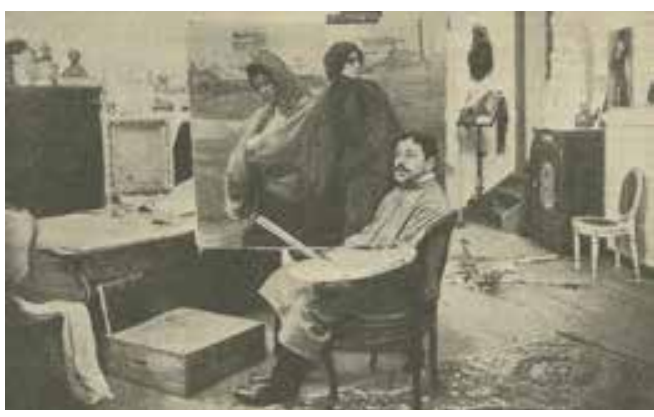

O pintor Constantino Fernandes a trabalhar no atelier (Branco, 1920: 21). Imagem digitalizada a partir de um original que pertence à coleção do autor.

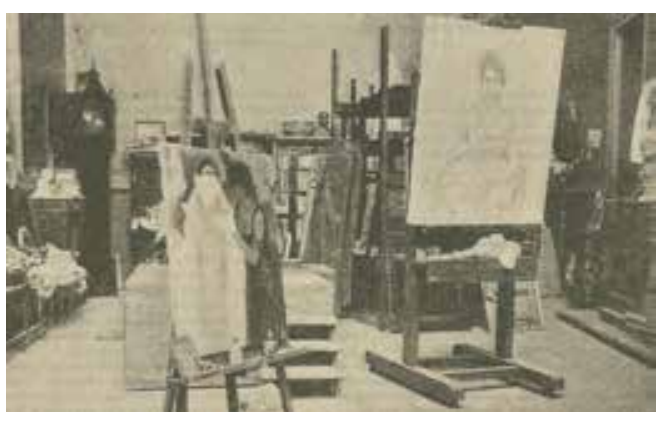

Vista geral do atelier (Branco, 1920: 23). Imagem digitalizada a partir de um original que pertence à coleção do autor. 


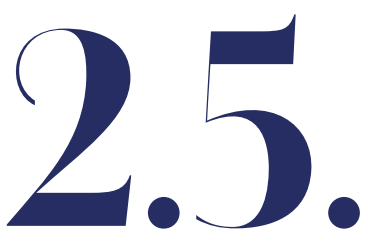

\section{Pintura e escultura}

\section{Casa/Atelier Artur Prat}

Artur Prat (1861-1918) encomendou, em 1912, o projecto para uma moradia, com dois ateliers distintos no seu interior, ao arquiteto Miguel Ventura Terra (18661919) na Avenida António Augusto de Aguiar (A.M.L., 1912, fl.1) (Collares, 1914: 1-4), ${ }^{17}$ a qual foi distinguida com a Menção Honrosa do Prémio Valmor em 1913 (C.M.L., 2004: 57).

No rés-do-chão o vestíbulo e a entrada são o eixo distribuidor. Este piso era a zona de serviço e ao fundo o atelier para escultura, semi-enterrado no terreno. Tinha entrada exterior independente para a fachada norte e uma janela lateral.

No primeiro andar era a habitação dos proprietários.

No segundo andar os dois quartos e arrecadação do atelier são iluminados pelas trapeiras da fachada principal. O atelier de pintura tem duplo pé direito e uma porta janela com varanda para a fachada norte. Logo por cima deste vão há um janelão que se prolonga até à cobertura, garantindo uma eficiente entrada de luz no interior que deveria ser controlada por meios artificiais. Tem uma galeria com acesso pelo sótão e uma porta para a galeria de exposição, iluminada zenitalmente por uma claraboia, com portas janelas para uma loggia e um terraço coberto virados a poente. Este espaço contrastava com o anterior em altura e luz, era ideal para expor obras de arte e receber convidados, além de que tinha vista sobre o Parque Eduardo VII.

Neste edifício os espaços dedicados à práctica da escultura e pintura estão integrados com os restantes espaços domésticos, assim como a dimensão dos vãos de acordo com o espaço interior. Desta forma a fachada principal é simétrica, com altos-relevos nos cantos da cimalha, e as trapeiras integram-se originalmente 
com o plano de fachada. A fachada norte é assimétrica e as loggias da sala de estar e da galeria de exposição destacam-se, culminando nas esculturas do próprio Artur Prat.

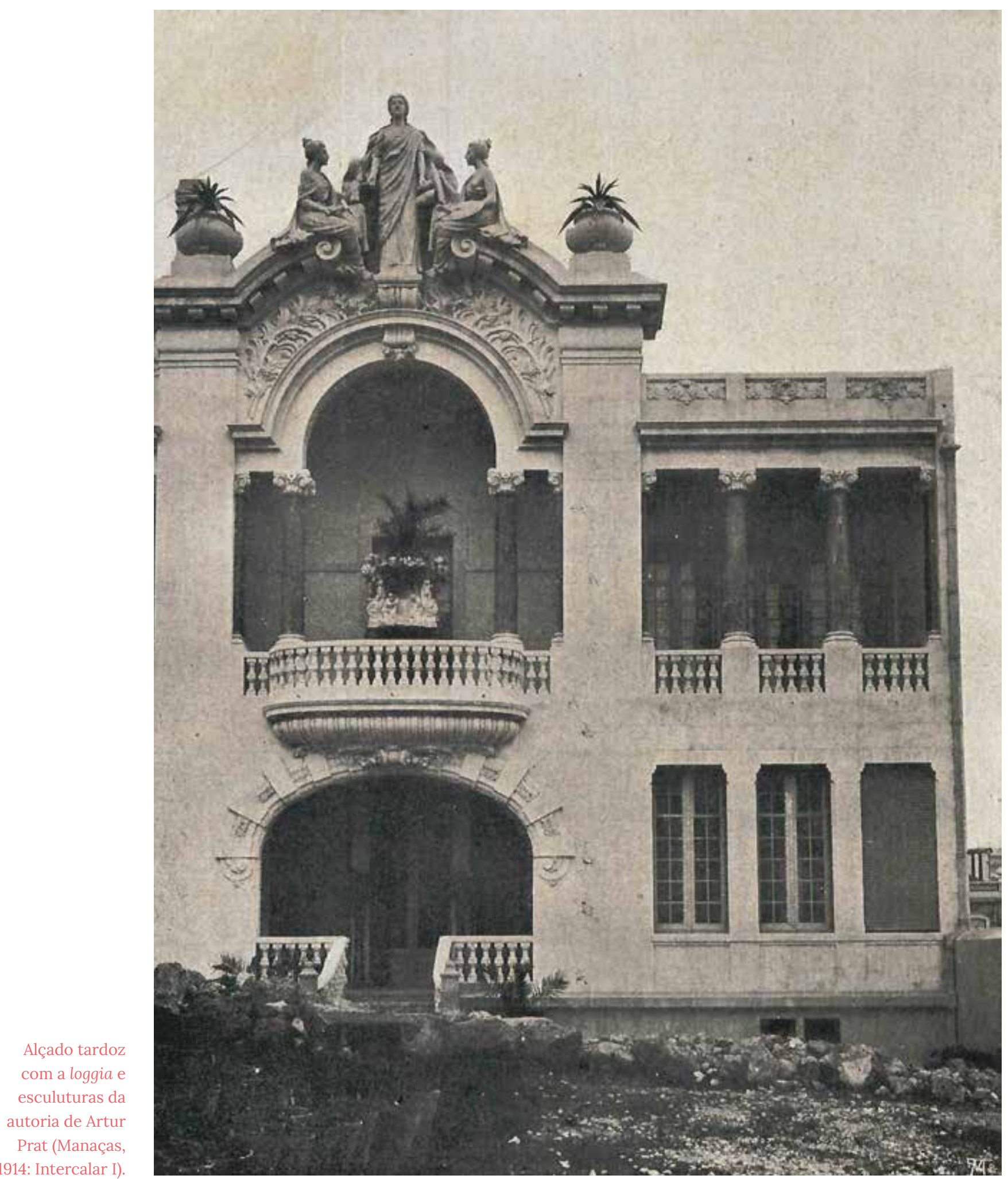

O edifício é atualmente a sede da Ordem dos Engenheiros. 


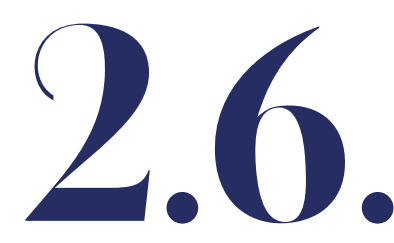

\section{Sem uso específico}

\section{Casa/Atelier Condes de Taboeira}

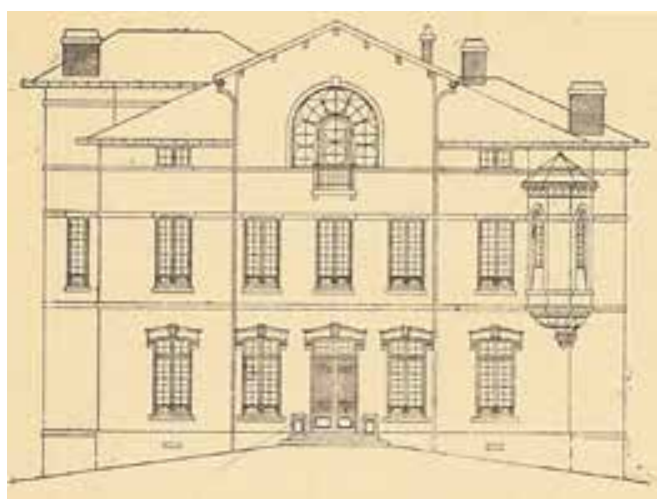

Fachada norte da Casa Condes de Taboeira (Collares, 1904: 250). O janelão do atelier com varanda no último piso e o volume do oratório no cunhal da fachada.
No ano de 1898 começou a ser construída uma moradia para o casal João Cardoso Valente (1859-1903), futuro $1^{\circ}$ conde da Taboeira, ${ }^{18}$ e María Aurora Ângela de Muñoz y Puig (1861-1945) na Rua da Arriaga em Lisboa (A.M.L., 1898: fl.1) (Collares, 1904: 249251). O arquiteto escolhido foi Miguel Ventura Terra e foi erigida pela firma Vieillard \& Touzet ${ }^{19}$ (Santos, 1996: 163).

Esta vasta moradia refletia a eficiente distribuição espacial da grande casa burguesa. No sótão tinha um atelier, cuja utilização não é especificada na planta, ${ }^{20}$ com um janelão e varanda virados a norte, ornamentado no exterior com azulejos ou pinturas a fresco. O volume deste espaço destacava-se no exterior, tinha o mesmo pé direito que nos pisos inferiores e telhado de duas águas contrastando com a restante cobertura. No cunhal da fachada norte e poente situava-se o oratório, destacado por um volume hexagonal. Estes elementos quebravam a simetria do desenho arquitectónico (Fevereiro, 2017b: 495-496).

No decorrer do século XX a moradia foi bastante alterada e é hoje a Embaixada do Iraque. 


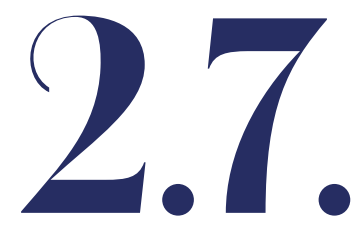

\section{Atelier rainha D. Maria Pia}

A maioria dos ateliers descritos já desapareceram e os que sobreviveram foram alterados ou adaptados para outras funções, todavia o Atelier da rainha D. Maria Pia (1847-1911) no Palácio Nacional da Ajuda é dos poucos que ainda conserva o ambiente original, embora adaptado a um circuito de visitantes devido à musealização do edifício. ${ }^{21}$

A rainha D. Maria Pia ao casar com o rei D. Luís I (1838-1889), em 1862, veio residir para o inacabado Palácio da Ajuda até à implantação da República em 1910. Com instinto natural para a decoração, a arquitetura e a colaboração inestimável do arquiteto Joaquim Possidónio Narciso da Silva (1806-1896) foram determinantes na transformação do andar térreo entre 1862 a 1865. Vários espaços foram redecorados e outros alterados de forma a serem adaptados ao modo de vida burguês oitocentista, numa estrutura palaciana ainda setecentista (Fevereiro, 2019: 181-212).

Nos anos que residiu no palácio a rainha foi introduzindo diversas modificações no seu interior; a Sala de Jantar precedida de uma Sala de Bilhar, em 1879, e a Capela do Andar Térreo, em 1897, respectivamente dos arquitetos Rafael da Silva Castro (c.1832-1892) ${ }^{22}$ e Miguel Ventura Terra.

No ano de 1887 a 1888 diversas obras foram realizadas, nomeadamente:

21

No presente estudo demos preferência a este atelier real em detrimento de outros que também existiram em Lisboa, como por exemplo o do rei D. Fernando II (1816-1885) no Palácio das Necessidades, o de pintura da rainha D. Amélia (1865-1951) em pavilhão autónomo nos jardins do Palácio das Necessidades e o do rei D. Carlos I no Palácio de Belém. Todos estes ateliers inevitavelmente foram adaptados a outras funções que não as iniciais, visto os edifícios se terem tornado em instituições do Estado.

Nesta investigação apresentamos novos dados biográficos de Rafael da Silva Castro e que nasceu por volta de 1832 em Lisboa e era filho de Joaquim Lopes de Castro da Silva e de Maria da Piedade. Casou na freguesia das Mercês a 20 de fevereiro de 1860 com Maria do Carmo Cordeiro, os quais tiveram os seguintes filhos: Maria nasceu na freguesia de São Mamede 27.02.1862 e morreu na dos Anjos 13.08.1939; Maria nasceu na de São Mamede 25.10.1863; Rafael da Silva Castro Júnior nasceu na de São Mamede 06.11.1865 e morreu na de Santa Isabel 18.02.1952 (casou na freguesia da Lapa 29.03.1890 com Emília Henriqueta Serrano) e António nasceu na de São Mamede 25.07.1867 e morreu na dos Anjos 16.09.1937. O arquiteto Rafael da Silva Castro faleceu na freguesia de Santa Isabel no dia 8 de outubro de 1892 à 1 h na Rua São João dos Bem casados n. ${ }^{\circ} 501 .^{\circ}$ andar. Todas as freguesias mencionadas pertencem ao concelho da cidade de Lisboa. 


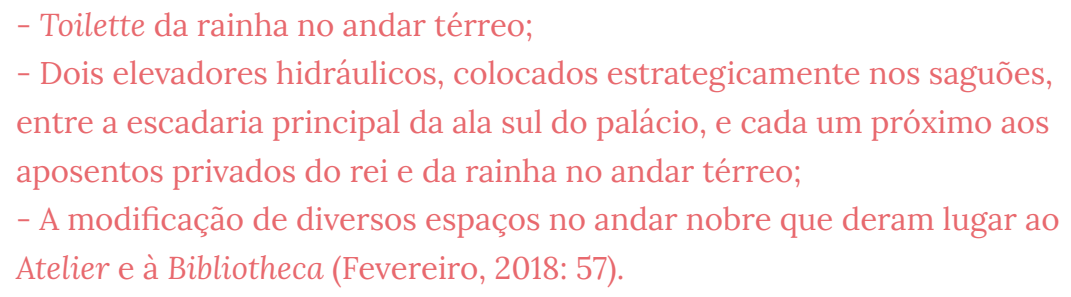

A inclusão destes espaços para um determinado uso foi ao encontro do gosto e prática que a Família Real tinha pela pintura, pela escultura, pelo desenho, pela arquitetura e também pela pintura em cerâmica.

Ao sair do elevador entra-se para um corredor longitudinal e, em frente, há uma porta para uma antecâmara. Este espaço tem do lado esquerdo uma instalação sanitária (de um quarto de cama), em frente a porta para a Bibiliotheca ao gosto da Renascença e do lado direito a porta para o Atelier inspirado no período Gótico. Estas duas épocas históricas estavam em voga na segunda metade do século XIX na Europa e nos Estados Unidos da América (Riley, 2004: 214-219).

No eixo central da porta da Bibliotheca está, na parede fronteira, a lareira ladeada por duas janelas com portadas interiores de vitrais coloridos com o monograma da rainha D. Maria Pia viradas a sul. O gosto neo-renascentista define a atmosfera introspectiva deste espaço, realçado pela luz coada dos vitrais que nos transporta para os studioli do século XV. Tem várias estantes para livros, telas a óleo, cadeirões e peças decorativas. As paredes e o teto plano em madeira são realçados por ornamentações em metal, conferindo uma elegância sofisticada. Este trabalho esteve a cargo do famoso entalhador Leandro de Sousa Braga (1839-1897). A porta da direita na antecâmara leva-nos directamente para o Atelier, também com boiseries do mesmo entalhador ao gosto neo-gótico. Este espaço encontra-se na extremidade sul/poente da ala sul do palácio. A nossa atenção é imediatamente dirigida para o janelão poente emoldurado por elementos arquitectónicos e de forma rectangular arredondado nos cantos superiores. Esta superfície de vidros permite uma boa incidência de luz natural, então controlada por cortinados e é o elemento cénico de maior relevância. O parapeito deste vão encontra-se a uma cota superior ao normal de forma a evitar a demasiada incidência de luz natural ao nível da nossa vista, além de enquadrar objectos decorativos e luminária, conferindo maior ênfase à moldura que se prolonga para o teto. No topo da moldura encontrase o brasão de armas coroado da rainha D. Maria Pia. O teto plano foi dividido em nove secções de dimensão igual com travejamento à vista. Na secção do meio pende um lustre de metal e a secção adjacente, para o grande janelão, tinha uma superfície envidraçada que nos dias de hoje se encontra oculta. Recebia luz de uma claraboia de esteira, mas foi tapada e o suposto mecanimo desactivado. A conjugação destas duas superfícies criava uma secção de luz, desmaterializando este espaço e efeito contrastante. Os meios artificiais regulavam a intensidade de luz diurna conforme a execução de uma determinada tarefa, de acordo com a posição solar e de forma a não ofuscar os seus ocupantes, não cansando assim os olhos. 
A luz artificial era assegurada pelo lustre mencionado e por outro de parede oposto ao grande janelão. Ambos eram inicialmente para gás, mas em 1910 já estavam adaptados à electricidade. Havia também um candeeiro em ferro forjado, com abat-jour vermelho em vidro, para petróleo e um candeeiro em latão de pé alto, com suporte para abat-jour de tecido, do tipo modérateur para azeite (Fevereiro, 2018: 55-57). ${ }^{23}$ O grande janelão foi complementado com duas serpentinas laterais para três velas de gás cada uma. O parapeito foi decorado com um par de serpentinas, para cinco velas cada uma e respectivas bobéches, e um relógio ao gosto da época de Luís XV. No parapeito estavam ainda dois castiçais, cada um para duas velas (A.P.N.A., 1912: 2560V-2626V). Toda esta luminária enquadrava-se com a atmosfera eclética do atelier, criando luz e penumbra em pontos específicos de forma a evidenciar um determinado enquadramento. Realce-se aqui algo que sabemos ser comum, mas não muito divulgado: a conjugação de iluminação a gás, a petróleo, a azeite, a velas e eléctrica no mesmo espaço no início do século XX.

A luz natural e artificial estava assim assegurada, compensando o uso intensivo da madeira e da tela castanha com motivo padronizado flor-de-lis estilizada na parede.

Na parede sul há também duas janelas, entre as quais fica uma lareira, que se prolonga para o teto com elementos arquitectónicos e ornamentações góticas. Na parede poente/norte que lhe fica fronteira há uma escadaria que tem início no grande janelão e um dragão (timbre da Casa de Bragança) no início do corrimão da guarda. A escadaria dá acesso a uma galeria e ao patamar da porta de uma arrecadação. A inclusão deste elemento arquitectónico quebra a escala com diferentes pontos de vista sobre o mesmo espaço. A escadaria era também usada como suporte de panejamentos e de outros objectos decorativos, criando diferentes cenários e enquadramentos conforme o gosto (A.P.N.A., 1912: 2560V-2626V). Nas guardas da escadaria estão esculpidos alternadamente o escudo das armas da casa real portuguesa e da casa de Saboia. Na arrecadação eram guardados em armários as fotografias, as aguarelas, as pinturas a óleo, os esquiços, as tintas e os pincéis, entre outros objectos. Tinha uma mesinha com um candeeiro para gás, um lavatório e um pequeno forno refratário para peças de cerâmica. Num pequeno compartimento estava a instalação sanitária (estes espaços foram demolidos na segunda metade do século XX) (A.P.N.A., 1912: 2560V-2626V). Debaixo da galeria há outra porta, de largura superior, que comunicava com a Arrecadação da Princeza (também demolida na segunda metade do século XX). 
A atmosfera eclética é complementada por armários, secretárias, cadeirões, bancos, mesas, cadeiras, relógio de caixa alta, biombos, entre outros objectos, criteriosamente escolhidos para enriquecer a decoração. Também esteve um órgão de tubos fotografado em 1889 e desenhado em aguarela pelo pintor espanhol Enrique Casanova (1850-1913), ${ }^{24}$ mas em 1910 já não estava e não foi descrito nos inventários posteriores. A maioria do mobiliário é ao gosto gótico, contudo a rainha foi incluindo uma mesa Louis XV, mobiliário oriental e uma estante em madeira ao gosto Arte Nova.

Pelo Atelier encontravam-se várias peças em cerâmica europeia ou oriental, como jarrões, uma travessa-peixe, uma taça, um gnomo com cerca de um metro de altura, um aquário chinês, pratos decorativos, um pote e um serviço de chá com motivos de coral sobre fundo branco, um vaso com montagem e pé em ferro forjado e outros vasos em bronze, assim como, estatuetas e outros objectos decorativos, várias floreiras e perfumadores em vidro (A.P.N.A., 1912: 2560V-2626V). Alguns desses objectos têm simbologia ligada à Casa Real ou associada à Natureza e aos astros.

Este era um espaço para trabalho e uma sala de estar informal de carácter familiar, cujo conforto está patente na disposição e escolha criteriosa de certos objectos. A atmosfera remete-nos para o estudo e para o gosto pela Arte, tão característico no século XIX. A contínua aquisição de peças por parte da rainha contribuiu para intensificar mais o gosto eclético deste espaço.

A prática da pintura e desenho não se resumia aos espaços descritos. Na Sala Verde, no piso térreo e parte dos aposentos privados da rainha D. Maria Pia, encontravam-se vários objectos para esse fim, nomeadamente; blocos de papel, desenhos a lápis, aguarelas, pincéis, pastas, estojos, prancheta, lápis para pastel e caixas com tintas para óleo e para aguarela. Também havia um atelier para a modelação de gesso e uma câmara escura para a fotografia no segundo piso, mas também foram demolidos na segunda metade do século XX. Nas várias arrecadações do palácio encontravam-se os seguintes objectos: mesa de armar exterior para desenho (vendida em leilão), tripé elástico em madeira para pintar no exterior (vendido em leilão), banco para pintura no exterior, dois cavaletes com pinturas do rei D. Luís, quatro telas para pintura e duas caixas com asas para transportar tintas, pincéis, frascos, entre outros objectos. Todo este material comprova que a rainha tinha apetência para as artes, assunto recentemente abordado numa exposição (Ribeiro, 2016). 


\section{Consideracões finais}
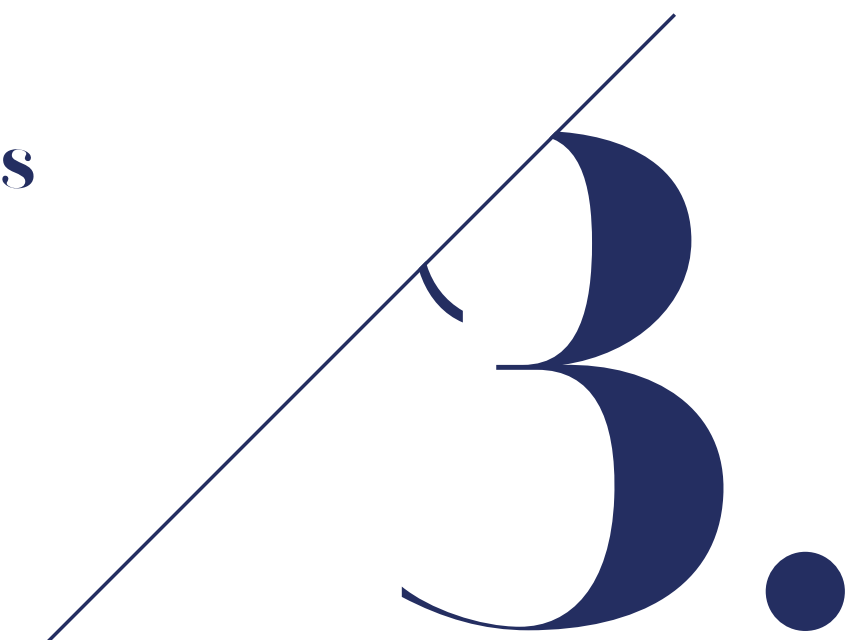

A partir de meados do século XIX o aproveitamento da luz natural foi fulcral na construção de novos ateliers, de acordo com a escala do seu interior e as funções pretendidas. No entanto, este espaço também passou a ser de estar e receber convidados, como no atelier da Duquesa de Palmela e da rainha D. Maria Pia. O seu desenho arquitetónico e decoração interior refletem as tendências estilísticas então em voga nos restantes países europeus.

No mesmo período a fotografia foi-se aperfeiçoando e tornou-se mais acessível ao público em geral. Esta situação foi aproveitada pelos fotografos na criação dos seus ateliers, que passaram a ser espaços de receção, captura e tratamento de imagens, essenciais para atrair o cliente. Todavia só foi possível a sua edificação graças ao desenvolvimento de novas técnicas construtivas como as estruturas em ferro, o uso intensivo do vidro e de sistemas mecânicos para regular a intensidade da luz solar, essenciais para a realização da fotografia. Efetivamente os mecanismos de sombreamento através de têxteis e de superfícies aprimoramse, tendo sido empregues em vãos de acordo com uma determinada atividade artística. Desta forma evitava-se demasiada incidência de luz num espaço para não esforçar a vista humana, o que poderia induzir em erro o uso de cores, o desenho e a feitura de determinado objecto. Este saber é visível nos ateliers de pintura que eram geralmente virados a norte e com duplo pé direito, exceto no que pertenceu ao pintor João Vaz e que propositadamente estava direcionado para o mar. Os ateliers de arquitetura estavam virados a poente ou a nascente, embora controlados e consoante o terreno, e os de escultura a norte ou a poente. Estes últimos eram geralmente em edifícios autónomos, ou separados do interior doméstico, devido ao pó resultante do trabalho da pedra.

No último quartel do século XIX a especialização das profissões artísticas despoletou novas abordagens: o atelier continuou a ser num edifício independente ou integrado na habitação. No seu interior passaram a existir espaços 
complementares como oficinas, instalações sanitárias e arrecadações. Alguns tinham galerias percorríveis para a visualização de diferentes ângulos sobre estrados e composições cenográficas, além de poderem dispor peças artísticas e decorativas. O atelier podia ser complementado com salas de estudo, exposição, recepção e galerias, onde se divulgava junto do público as últimas criações. Esta sofisticação espacial e relação em planta é visível na casa/atelier Malhoa e no desaparecido atelier de Constatino Fernandes. Forçosamente esta diposição interna manifestou-se no desenho arquitetónico exterior, onde foram exploradas referências ecléticas oitocentistas. No entanto, à medida que o século XIX terminou a questão da casa à portugueza e a corrente estética Arte Nova ganharam força, influenciando os projetistas portugueses e que procuraram se manter atualizados. Estas referências e conhecimento são evidentes na manipulação volumétrica, na assimetria, na adaptação de um edfício a um terreno e na disposição espacial interior na obra arquitetónica desenvolvida. Contudo é forçoso mencionarmos a crescente valorização dos artistas portugueses junto do público, o que possibilitou o consumo de obras de arte e por conseguinte a disponibilidade financeira para a construção destes edifícios pelos artistas.

A maior parte destes ateliers desapareceu, mas a sua memória permanece viva na documentação existente, imprescindível na caracterização e na forma como a feitura das artes eram abordadas neste período. 


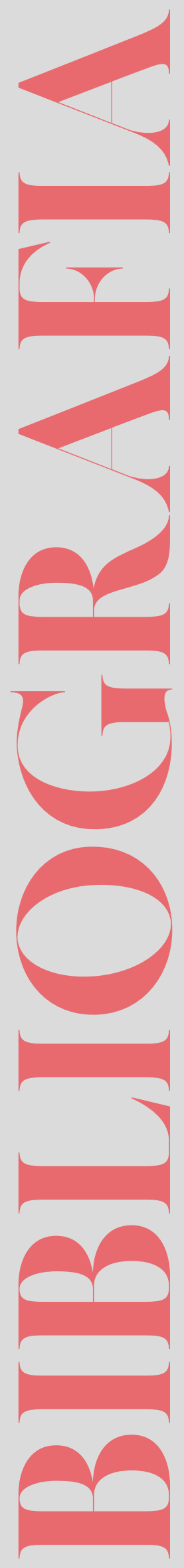

Araújo, Nuno Borges de (2017a). A fotografia e o postal ilustrado: origens e influências. In Martins, Moisés de Lemos (Ed.), Os postais ilustrados na vida da comunidade (pp. 55-88). Braga, CECS - Centro de Estudos de Comunicação e Sociedade da Universidade do Minho.

Araújo, Nuno Borges de (2017b). Lisbon and its region: stereoscopic photography, c. 1853-1890. International Journal on Stereo \& Immersive Media. Lisboa, ECATI, Department of Communication Sciences, Universidade Lusófona Vol. 1 (2), 4-31.

Araújo, Nuno Borges de (2011). A singular viagem do fotógrafo Jean Laurent a Portugal, em 1869. CEM - Cultura, Espaço E Memória. Porto/Braga (1), 87-108.

Ávila e Bolama, $2 .^{\circ}$ Marquês de (1912). A nova carta chorographica de Portugal. Lisboa: Imprensa Lucas.

Borsi, Franco e Wieser, Hans (1996). Bruxelles Capitale de L'Art Nouveau. Braine- I'Alleud: Éditions J. M. Collet.

Câmara Municipal de Lisboa (C.M.L.) (2004). Lisboa - Prémio Valmor. Lisboa: Câmara Municipal de Lisboa, Pelouro de Licenciamento Urbanístico e Reabilitação Urbana.

Caron, Claude e Van Weyenbergh, Claire (1968). Le style Napoléon III, histoire... caractéristiques... usages. Verviers: Gerard.

Fevereiro, António Cota (2019). A Sala de Marmore no Palácio Nacional da Ajuda. Revista de Artes Decorativas. (7), 181-212.

Fevereiro, António Cota (2018). Iluminação da Casa Real Portuguesa. Os Candeeiros do Palácio Nacional da Ajuda. Oeiras: Mazu Press.

Fevereiro, António Cota (2017a). A Arte Nova em Lisboa. Cadernos do Arquivo Municipal. 2. ${ }^{a}$ Série, (7), 227-255.

Fevereiro, António Cota. (2017b). Os espaços de culto privados na transição do século XIX para o XX. In Queiroz, Francisco (Coord.), Arte, Cultura e Património do Romantismo. Actas do $1^{\circ}$ Colóquio "Saudade Perpétua" (pp. 476-557). Porto: CEPESE - Centro de Estudos da População, Economia e Sociedade.

Fevereiro, António Cota (2016). The Art Nouveau tiles as a frame to architecture in Portugal. ARTis ON - Edição especial - atas do AzLab\#14 Azulejos and Frames Special issue. 1. ${ }^{a}$ Série, (2), 61-74. 
Fevereiro, António Cota. (2012). Genealogia, dados biográficos e obra de arquitetos, artistas e construtores civis portugueses do século XIX e XX. In Machado, José Carlos Soares (dir.), Raizes e Memórias (pp. 135-152). Lisboa: Associação Portuguesa de Genealogia, PP. 241-292.

Griffo, Massimo (1998). Revivalism. In Disertori, Andrea; Cozzi, Elisabeth (Coord.), Furniture: from Rococo to Art Deco (pp. 540-551). Colónia, Evergreen.

Queirós, José (1907). Ceramica Portugueza. Lisboa: Typograhia do Annuario Commercial.

Ramos, Rui Jorge Garcia (2010). A Casa - Arquitectura e Projecto Doméstico Na Primeira Metade Do Século XX Português. Porto: Faculdade de Arquitetura da Universidade do Porto.

Ribeiro, Irene (1994). Raul Lino, Pensador Nacionalista da Arquitectura. Porto: Faculdade de Arquitectura da Universidade do Porto.

Ribeiro, José Alberto (Coord.) (2016). Um Olhar Real - Obra Artística da Rainha D. Maria Pia. Lisboa: Palácio Nacional da Ajuda e Imprensa Nacional-Casa da Moeda.

Riley, Noël (2004). Grammaire des arts decoratifs: de la Renaissance au Postmodernisme. Paris: Flammarion.

Sabugosa, Conde de (1921). Embrechados. Lisboa: Portugal-Brasil.

Saldanha, Sandra da Costa (2006). Nobre amadora, Mulher escultora. A obra de Maria Luísa de Sousa Holstein (1841-1909), $3^{\text {a }}$ duquesa de Palmela. Margens e Confluências. (11), 99-123.

Sembach, Klaus-Jürgen (1996). Art Nouveau. Colónia: Taschen.

\section{Arquivo Nacional da Torre do Tombo, Assentos Paroquiais da cidade de Lisboa}

Distrito e concelho de Lisboa, freguesias: Encarnação, Lapa, Mercês, Santa Isabel, Santos-o-Velho e São Mamede.

\section{Documentação em arquivo}

Arquivo Municipal de Oeiras (A.M.O.), Nicola Bigaglia (1905), Projecto de uma casa d habitação que João Vaz deseja construir no terreno que possui na quinta de S. Mattheus, Dáfundo, freguesia de Carnaxide, concelho d'Oeiras. 33/1905, fl.1. 
A.M.O., Álvaro Augusto Machado (1906), Projecto que Antonio Augusto da Costa Motta deseja construir em Algés. 5/1906, fl.1.

Arquivo Municipal de Lisboa (A.M.L.) (1882), Projecto de uma galeria photographica que Damião da Graça deseja construir em ferro e madeira, no predio pertencente à Ex.ma Camara Municipal de Lisboa, sito no Pateo do Regedor N.os 1 a 4 freguezia de S.ta Justa. 44/1ªREP/PG 18821, fl. 1.

A.M.L., Miguel Ventura Terra (1898), Projecto de casa para João Cardoso Valente. 2925/1REP/PG 18981, fl. 1.

A.M.L., Manuel Joaquim Norte Júnior (1904a), Projecto de construcção que José Vital Branco Malhoa pretende fazer no seu terreno sito na Rua Antonio Maria d'Avellar tornejando para a Rua Pinheiro Chagas, freguezia de S. Sebastião da Pedreira, 5 Bairro. 1464/1ªREP/PG 19041, fl. 1.

A.M.L., Nicola Bigaglia (1904b), Projecto de casas, ateliers, oficinas e depósitos Nicola Bigaglia. 5767/1ªREP/PG 19041, fl. 1.

A.M.L., Nicola Bigaglia (1906), Projecto de casas, oficinas e depósitos Nicola Bigaglia. 3503/1ªRP/PG/19041, fl. 1.

A.M.L., Manuel Joaquim Norte Júnior (1910), Projecto de modificação de um atelier que Manuel Joaquim Norte Junior pretende construir no seu terreno sito na nova Alameda de D. Estephania, freguesia de S. Jorge d'Arroyos - $2^{\circ}$ Bairro. 3224/DAG/ PG/19101, fl. 1.

A.M.L., Miguel Ventura Terra (1912), Projecto de casa Artur Prat. 4637/1²REP/ PG/19121, fl. 1.

Arquivo Palácio Nacional da Ajuda (A.P.N.A.) (1911-1914), Inventário Judicial do Palácio Nacional da Ajuda.

\section{Periódicos}

Achilles (1909, fevereiro). Uma casa artística, Propriedade do sr. José Malhôa, Architecto, Norte Junior. A Architectura Portugueza. Ano II (2), 5, 7 e Intercalar III.

Algumas informações (1888). Algumas informações ácerca da Exposição Industrial Portugueza de 1888 - Aviso aos Srs. Industriaes. A imprensa, revista scientifica, litteraria e artistica. Vol. II (32 e 33), 66-69.

Branco, Affonso (1920, julho 12). Os Grandes Mortos, Constantino Fernandes. A Ilustração Portugueza. 2. ${ }^{a}$ Série (751), 19-24. 
Carvalheira, Rosendo Garcia de Araújo (1902, novembro 1). A Arte em Portugal, Um grande artista. Brasil-Portugal. (91), 681-683.

Collares, E. Nunes (1904, dezembro 10). Casa da Ex.ma Sr. ${ }^{a}$ Condessa de Taboeira, Na Rua Arriaga, Architecto, sr. Ventura Terra. A Construcção Moderna. Ano V (152), 249-256.

Collares, E. Nunes (1906a, outubro 10). Casa e atelier de artista, A construir em Algés, Architecto, sr. Alvaro Machado. A Construcção Moderna. Ano VII (201), 65-72.

Collares, E. Nunes (1906b, outubro 1). O atelier de um pintor, Architecto, sr. Tertuliano de Lacerda Marques. A Construcção Moderna. Ano VII (200), 57-64.

Collares, E. Nunes (1912, outubro). Casa do Ex.mo Sr. João Vaz, No Alto do Dáfundo, Architecto sr. N. Bigaglia. A Architectura Portugueza. Ano V (10), 37-40.

Collares, E. Nunes (1914, janeiro). Casa do Ex.mo Sr. Artur Prat, No Parque Eduardo VII com frente para a avenida Antonio A. Aguiar, Arquitecto, Sr. Ventura Terra. A Architectura Portugueza. Ano VII (1), 1-4.

Manaças, Manoel (1912, outubro). Casa do Ex.mo Sr. João Vaz, No Alto do Dáfundo, Architecto sr. N. Bigaglia. A Architectura Portugueza. Ano V (10), 37-40 e Intercalar XIX e XX. 
Manaças, Manoel (1914, janeiro). Casa do Ex.mo Sr. Artur Prat, No Parque Eduardo VII com frente para a avenida Antonio A. Aguiar, Arquitecto, Sr. Ventura Terra. A Architectura Portugueza. Ano VII (1), 1-4 e Intercalar I e II.

Marvile, Lina (1909, maio). Em casa dos artistas, José Malhôa. Serões. 2. ${ }^{a}$ Série (47), 357-362.

O'Neill, Maria (1909, agosto 2). A Duqueza de Palmella Esculptora. Illustração Portugueza. 2. ${ }^{\text {a }}$ Série (180), 131-138.

O pintor (1906, maio 7). O pintor Malhôa no Brasil. Illustração Portugueza. 2. ${ }^{a}$ Série (11), 329-337.

\section{Teses e dissertações}

Fevereiro, António Cota (2011). Álvaro Augusto Machado, José António Jorge Pinto e o movimento arte nova em Portugal (Dissertação de Mestrado em Arquitectura). Universidade Lusíada de Lisboa, Lisboa.

Santos, António Maria dos Anjos (1996). Para o estudo da arquitectura industrial na região de Lisboa (1846-1918) (Tese de Mestrado em História da Arte Contemporânea). Universidade Nova de Lisboa, Lisboa. 

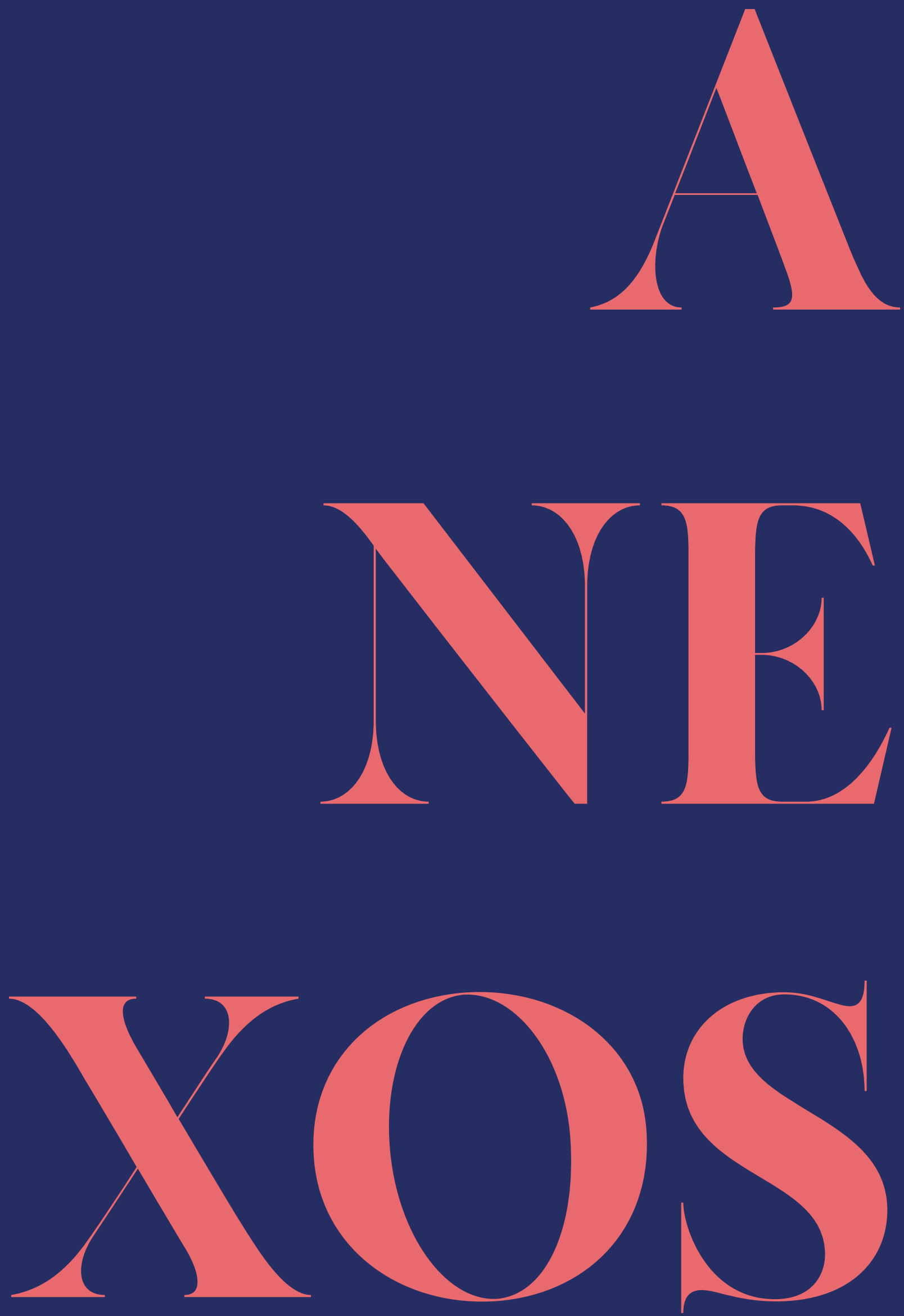
O Município de Melgaço, na pessoa do seu Presidente, Manoel Batista Calçada, reconhece o mérito, a qualidade e a relevância do trabalho de investigação e inventariação dos fornos comunitários de Castro Laboreiro e Lamas de Mouro, para o município de Melgaço, no sentido da sua salvaguarda e divulgação, e agradece a Diana Alexandra Simões Carvalho por este projecto da sua iniciativa e que levou a bom porto entre 2014 e 2017.

Melgaço, 28 de maio de 2019

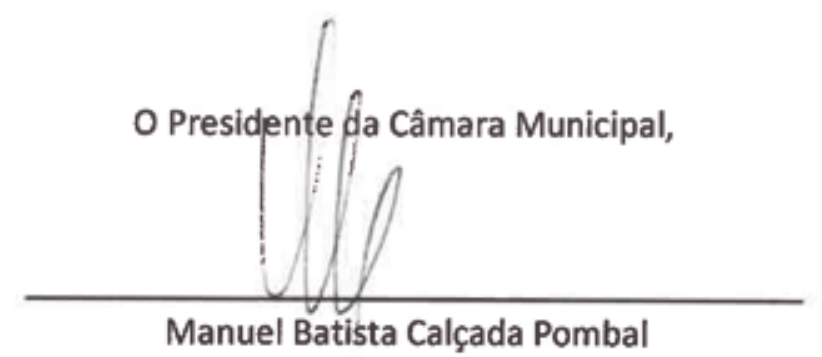




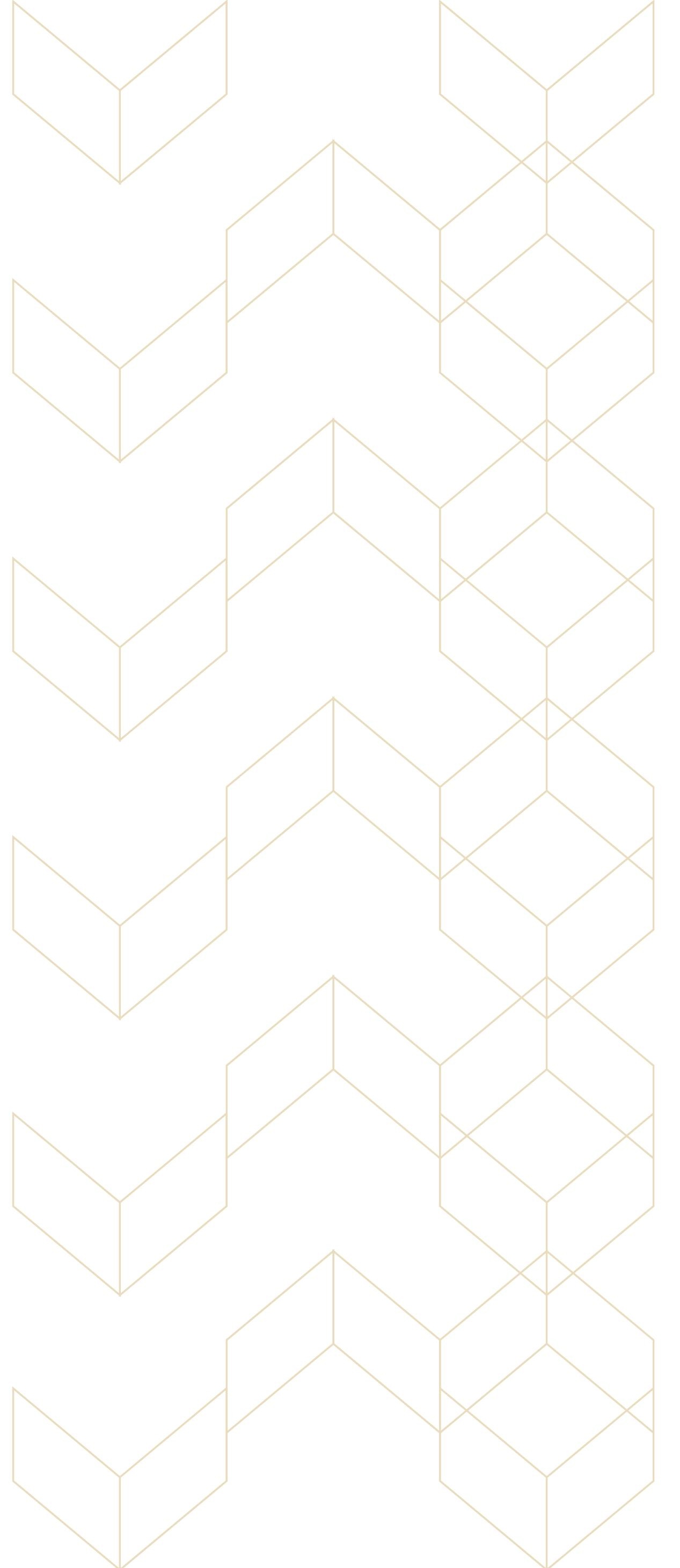




\section{Pelo sonho ć que vamos.}

Comovidos c mudos.

Chegamos? Náo chegamos?

I Iaja ou não frutos.

Pelo Sonho ć que vamos.

Basta a fé no que temos.

Basta a espcranca naquilo

Que talvez não tercmos.

Basta que a alma demos.

Com a mesma alegria.

to que desconhecemos

Eao que ć do dia a dia.

Chegamos? Não chegamos?

Partimos. Vamos. Somos."

Sebastião da Gama 
O início das publicações científicas é sempre um período muito difícil, exigindo dos editores, autores e técnicos uma dedicação extrema e dos leitores uma crença e paciência significativas. Apenas assim, conseguimos ultrapassar as naturais dúvidas dos novos projetos e, a prazo, afirmar os periódicos nas suas áreas de conhecimento, obtendo o reconhecimento da comunidade científica e dos leitores em geral, como atestam as primeiras indexações, Crossref, Latindex - Sistema Regional de Información en Línea para Revistas Científicas de América Latina, el Caribe, España y Portugal e Directory of Research Journals Indexing. A Herança não tem sido exceção. Com a publicação do V2N2, concluímos com sucesso o segundo ano de atividade, contando já com artigos em número e qualidade suficientes para garantir o lançamento do V3N1 e cumprir escrupulosamente os prazos de publicação e as metas editoriais definidas para 2020. Mas, para tal, foi vital o empenho de todos, sem exceção, aos quais a equipa Ponteditora reconhece o contributo e agradece profundamente.

\section{Boas leituras!}

